Geology of

San Nicolas Island

California

GEOLOGICAL SURVEY PROFESIONAL PAPER 369

Prepared in cooperation with the U.S.

Department of the Navy, Office of

Naval Petroleum and Oil Shale

Reserves

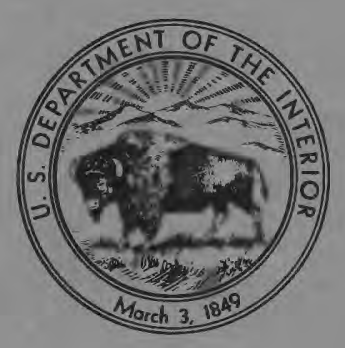




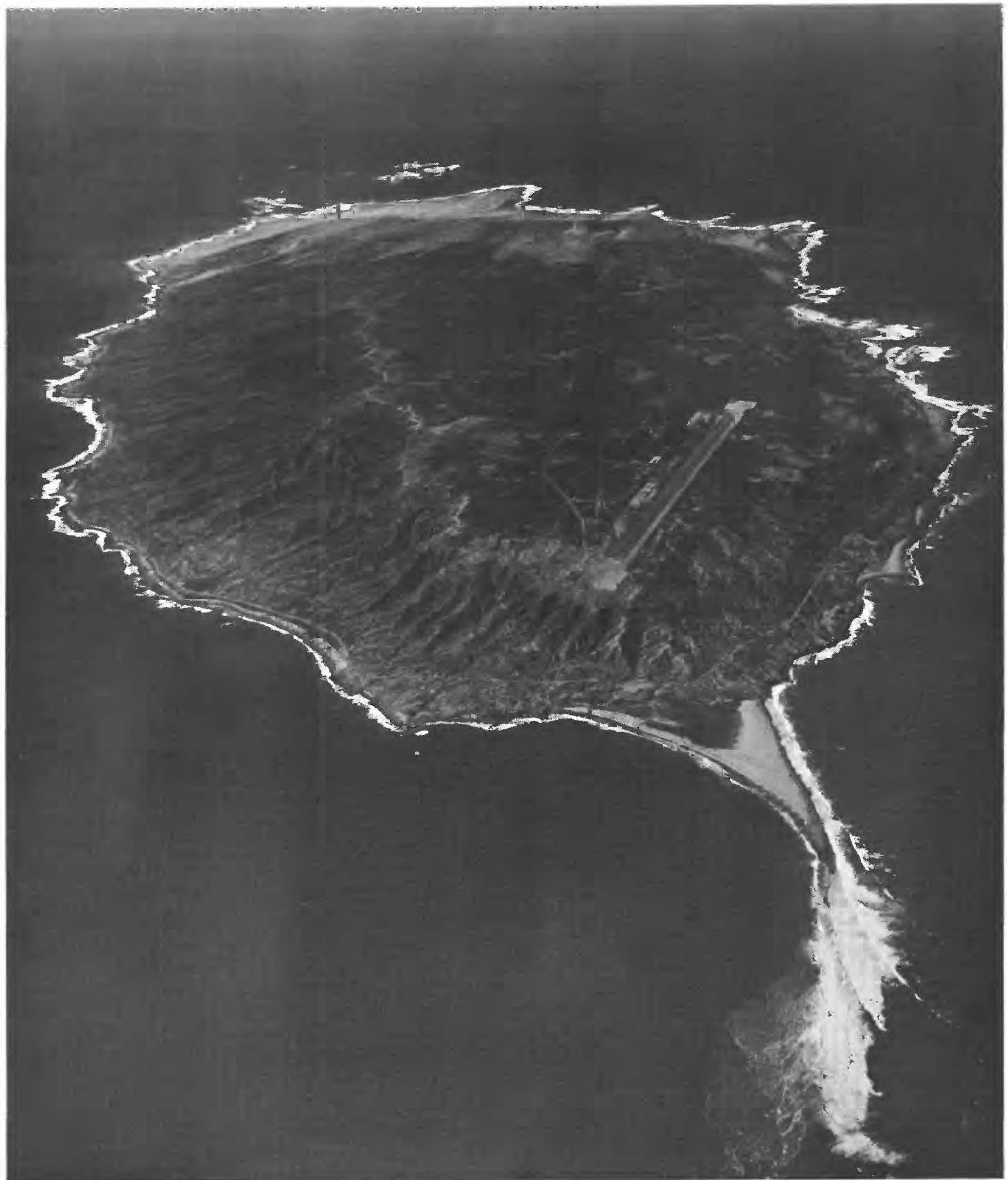

Oblique aerial photograph of San Nicolas Island viewed from the southeast. 
Geology of

San Nicolas Island

California

By J. G. VEDDER and ROBERT M. NORRIS

GEOLOGICAL SURVEY PROFESSIONAL PAPER 369

Prepared in cooperation with the U.S.

Department of the Navy, Office of

Naval Petroleum and Oil Shale

Reserves

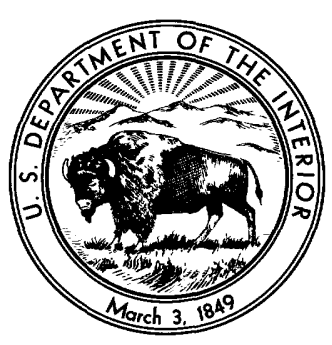

UNITED STATES GOVERNMENT PRINTING OFFICE, WASHINGTON : 1963 


\section{UNITED STATES DEPARTMENT OF THE INTERIOR STEWART L. UDALL, Secretary GEOLOGICAL SURVEY \\ Thomas B. Nolan, Director}

The U.S. Geological Survey Library catalog card for this publication appears after index. 


\section{CONTENTS}

Abstract

Introduction

Purpose and scope of report.

Location and accessibility

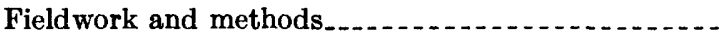

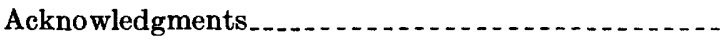

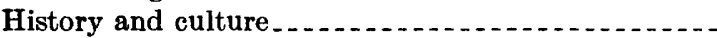

Climate, vegetation, and wildlife

Regional structure and stratigraphy

Geomorphology ........... . .

Geomorphic setting of the island platform .......

General features of the island . . .

Terraces...

Drainage

Dunes.....

Landslides .... . . . . . .

Beaches. . . . . . . .

Stratigraphy _.......

Concealed rocks . . .

General features of the exposed rocks

Tertiary system . . . . . . .

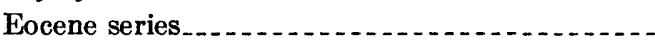

General features of the Eocene rocks......

Description of mapped units. ..........

Laboratory analyses of Eocene sandstone samples

Source rocks of the Eocene sandstones.....

Correlation . . - .

Igneous rocks ...

Quaternary system

Pleistocene series. . .

Terrace deposits

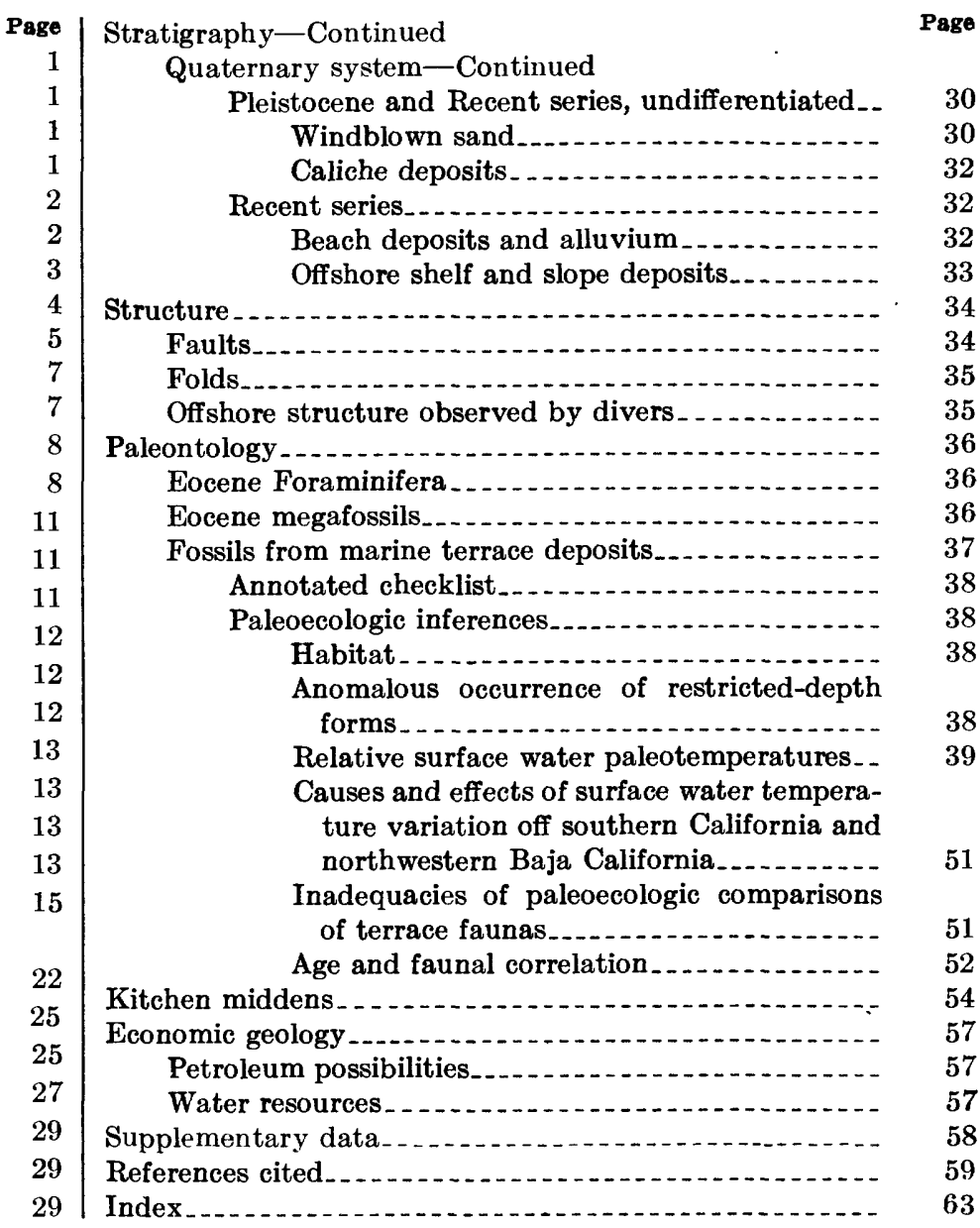

\section{ILLUSTRATIONS}

[Plates are in pocket]

Frontispiece. Oblique aerial photograph of San Nicolas Island viewed from the southeast.

Plate 1. Index map of part of the continental borderland and coastal area of southern California.

2. Pleistocene fossil localities and traces of inferred inner margins of the terrace platforms.

3. Geologic map and sections of San Nicolas Island.

4. Bathymetry and geologic observations on the sea floor west of San Nicolas Island.

5. Stratigraphic sections of the Eocene strata exposed on San Nicolas Island. 
FIgURe 1. Reconnaissance geologic map of the sea floor off southern California

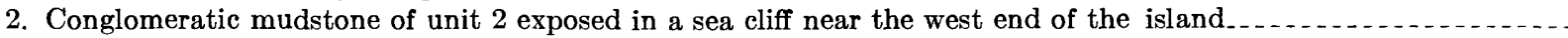

3. Lenticular beds of conglomerate, breccia, and sandstone in unit 4 near the west end of the island ...................

4. Clastic fragments of siltstone and mudstone embedded in a matrix of sandstone contained in unit $4 \ldots \ldots$

5. Slope-forming siltstone beds of unit 6 overlain by cliff-forming sandstone beds of unit 7 along the east wall of Sand Dune Canyon ...

6. Thick-bedded sandstone typical of the lower part of unit 7 exposed in a sea cliff about one-third of a mile southeast

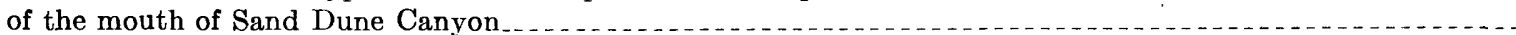

7. Honeycomb weathering exhibited on the windward surfaces of sandstone beds in unit 7 near Dutch Harbor....

8. Interbedded sandstone and siltstone in unit 8 exposed in a deep ravine southwest of Jackson Hill . . . . . . . .

9. Well-bedded siltstone and fine-grained sandstone in the lower part of unit 20 exposed in a sea cliff at the east end of the island . .

10. Histograms showing grain size in samples of Eocene sandstone

11. Correlation chart of Eocene formations in central and southern California

12. Narrow igneous dike cutting a sandstone bed about three-quarters of a mile east of Dutch Harbor

13. Generalized block diagram showing the relation of the terrace deposits to the terrace platform

14. Well-preserved mollusks in a marine terrace deposit at an altitude of 725 feet near fossil locality $\mathrm{SN}-2 \ldots$

15. A view southeast along the old sea cliff of the well-developed 100 -foot terrace near Coast Guard Beach. .......

16. Quaternary dune deposits and caliche at an altitude of about 825 feet on the western upland surface of the island.

17. A westward view of a normal fault exposed near the east end of the island

18. Map showing distribution of selected fossil localities in terrace deposits of southern California and northwestern Baja California ...

19. Kitchen midden deposits and burial in partly cemented dune sand near Seal Beach . . . . . . . . . . . . .

\section{TABLES}

TABLE 1. Designation, altitude, fossil localities, and description of terraces on San Nicolas Island

composition, porosity, and permeability of Eocene sandstone outcrop samples from San Nicolas Island.-

3. Checklist of Eocene mollusks from San Nicolas Island

4. Checklist of fossils from terrace deposits of Pleistocene age on San Nicolas Island living faunas only as extralimital and near limital, or that are not known to be living

6. List of invertebrates observed in kitchen middens

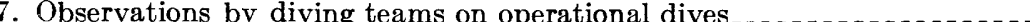

8. Eocene mollusk fossil locality descriptions

9. Pleistocene fossil locality descriptions. 


\title{
GEOLOGY OF SAN NICOLAS ISLAND, GALIFORNIA
}

\author{
By J. G. Vedder and Robert M. Norris
}

\begin{abstract}
San Nicolas Island lies approximately 65 miles seaward from the nearest part of the southern California mainland and is the outermost of the Channel Island group. The island has an area of about 32 square miles and a maximum relief of 907 feet.

The exposed Tertiary section on San Nicolas Island consists of nearly 3.500 feet of alternating marine sandstone and siltstone beds that contain minor amounts of interbedded conglomerate and pebbly mudstone. This sedimentary rock sequence has been divided into 35 mappable units, all of

higher emergent terraces may represent wave-abraded platforms that were eroded during eustatic changes of sea level combined with tectonic uplift. The lowest emergent terrace and the submerged terraces may have been cut during eustatic sea-level changes followed by very slight regional seaward warping that did not appreciably affect any of the platforms on the island. Presumably all the terrace platforms on San Nicolas Island were cut later than the middle Pleistocene diastrophism recognized elsewhere in southern California.
\end{abstract} Eocene age. The mineral content of the sandstone samples suggests a source area of plutonic igneous rocks of intermediate composition with lesser contributions from metamorphic rocks adjacent to the igneous bodies. Several small andesitic dikes of Miocene (?) age intrude the Eocene sedimentary rocks near the southeast end of the island. Dune sand and fossiliferous marine terrace deposits of Quaternary age cover most of the central and western parts of the island. A brief reconnaissance of the extensive kitchen middens and the related dune deposits indicates not only an increase in aridity but also a diminishing of the aboriginal population in early Recent time.

Structurally, San Nicolas Island is a broad, complexly faulted anticline that roughly parallels the long dimension of the island and plunges gently southeast, with its crest near the southwest shoreline. Two sets of intersecting faults, which trend approximately N. $30^{\circ} \mathrm{W}$. and N. $80^{\circ} \mathrm{E}$. and offset the fold axis, seem to be contemporaneous. Most of the faults are high-angle normal faults with a maximum throw of 800 feet on the north-trending set and 650 feet on the east-trending set. Underwater geologic investigations off the west end of the island indicate that the axis of the anticline extends northwest and that a fault pattern similar to that exposed on the island exists on the sea floor. The age of the main faulting episode may be pre-middle Miocene with continuing lesser movement through late Pleistocene time.

Foraminiferal assemblages that best correlate with faunas of late Eocene age elsewhere in California occur in all the siltstone units. The only significant Tertiary molluscan fauna probably is middle to late Eocene in age. More than 250 species of marine invertebrates collected from 11 terrace platforms suggest a late Pleistocene age for the terrace deposits and indicate environmental conditions nearly the same as at present. These fossil assemblages seem to show slight surface-water temperature variation at different terrace levels.

Seven well-developed wave-cut platforms and seven additional less distinct levels of marine planation are recognized on the island at altitudes from 25 to 900 feet. Several submerged terraces are present on the shelf adjacent to the island, the lowest being about 400 feet below sea level. The

\section{INTRODUCTION}

\section{PURPOSE AND SCOPE OF REPORT}

Geologic investigations to evaluate the petroleum potential of San Nicolas Island were undertaken early in 1955 by the U.S. Geological Survey at the request of the Director, Naval Petroleum Reserves. The purpose of the present report is to make available the geologic information obtained for the Department of the Navy during the 11 months of fieldwork on the island and parts, of the adjacent continental shelf.

Because little has been published concerning San Nicolas Island, brief introductory statements are included in this report to describe the climate, vegetation, wildlife, and history of the island. A part of the paper is devoted to a résumé of the regional structure and stratigraphy of the continental borderland off southern California as an introduction to the geology of the island; a short section on the physiography of the island and surrounding shelf area follows. Descriptive geology of the Tertiary and Quaternary rocks and unconsolidated sediments exposed on and around the island composes the bulk of the report, with shorter sections on laboratory analyses, the fossil content and paleoecology of the sedimentary rocks, and the character of the aboriginal shell mounds.

\section{LOCATION AND ACCESSIBILITY}

San Nicolas Island is the outermost of a group of eight islands off the coast of southern California and is a part of Ventura County (pl. 1). The San Nicolas Island quadrangle, of which more than half is ocean, lies between long $119^{\circ} 25^{\prime} 30^{\prime \prime}$ and $119^{\circ} 35^{\prime} \mathrm{W}$., and lat 
$33^{\circ} 12^{\prime}$ and $33^{\circ} 18^{\prime} \mathrm{N}$. The island is located approximately 80 statute miles south of Santa Barbara, about 90 miles southwest of Los Angeles, and almost 120 miles west of Oceanside. The total land area is about 32.2 square miles, and the maximum dimensions are 9.7 by 3.7 miles.

At present the island and surrounding waters are under the jurisdiction of the Naval Air Missile Test Center at Point Mugu; consequently, authorization must be obtained from the Navy to visit the island. Transport to the island is provided by Navy cargo aircraft from the air station at Point Mugu or by the Navy Crash Boat Division at Port Hueneme.

\section{FIELDWORK AND METHODS}

Geologic mapping of San Nicolas Island was begun by R. L. Harbour and R. J. Burnside in March 1955. After May 1, 1955, J. G. Vedder directed the field party and was later joined by R. M. Norris and D. J. Milton. S. R. Dabney and T. M. Eisner were employed as field assistants and aqualung divers. The first field season was concluded September 29, 1955. On May 1, 1956, a preliminary geologic map of San Nicolas Island accompanied by a short text (Vedder and others, 1956) was released for public inspection with the approval of the Director of Naval Petroleum Reserves. J. G. Vedder, R. M. Norris, and N. C. Privrasky resumed fieldwork on the island in June 1956 with G. $P$. Frymire assisting in the diving operations and with the photography. Fieldwork was completed in September 1956.

Surface mapping of San Nicolas Island was done on aerial photographs (approximate scales, $1: 4,800$; $1: 8,000 ; 1: 9,600)$. The geology was transferred from the photographs to the San Nicolas Island quadrangle map, (scale 1:24,000, 1952), which was enlarged to a scale of $1: 12,000$ and extended westward, beyond the quadrangle boundary, to include the area where underwater geologic work was done. Seventeen stratigraphic sections were measured and systematically sampled for foraminiferal study. Samples obtained by a jeep-mounted auger aided in determining the thickness and lithology of the Quaternary deposits.

Diving operations were undertaken on the shelf area off the west end of San Nicolas Island to supplement the geologic mapping on shore and to further evaluate the nature and extent of the structural features. More than 100 dives were made during the summer of 1955 , and approximately 50 additional dives were made in the summer of 1956. Geologic information was obtained on 98 dives at depths ranging from 30 to 120 feet. Rock samples, strike and dip determinations, and photographs were taken in conjunction with the underwater geologic studies. The methods of geologic diving outlined by Dill and Shumway (1954) and by Menard and others (1954) were employed with a few modifications.

Self-contained underwater-breathing apparatus was used by the divers. The lack of a harbor on San Nicolas Island during 1955 and 1956 required the use of a 122 foot landing craft (LCU) to move the diving crews on and off the island. A 26-foot motor whaleboat was used as a diver's tender.

Reference points for offshore position location were erected at six locations along the western shore of the island. Two temporary auxiliary marker buoys were set to augment the shore reference points during the second-season's operation. All of the reference points were located from known triangulation stations by planetable and alidade surveys. Horizontal sextant angles to the shore stations and to the marker buoys were used for offshore position location. Because of operational difficulties the position of the outer offshore stations probably is accurate only to within 100 to 150 feet. Stations nearer shore are presumably accurate to within 50 feet or less.

\section{ACKNOWLEDGMENTS}

The provision of transportation, boats and boat crews, and other equipment and supplies by the Island Facilities Officer and the Officer-in-Charge, San Nicolas Island, is gratefully acknowledged. New aerial photographs promptly furnished by Composite Squadron VC-61, Naval Air Station, Miramar, expedited the geologic mapping. The assistance extended by Mr. R. E. Jones of the Naval Civil Engineering Research Laboratory, Port Hueneme, in supplying crews and equipment to set marker buoys is appreciated. H. W. Menard, E. L. Hamilton, and R. F. Dill of the Naval Electronics Laboratory at Point Loma kindly offered advice concerning diving equipment and geologic diving techniques. Instructors from Scripps Institution of Oceanography trained the divers in the use of selfcontained underwater-breathing apparatus before the first season of diving.

Leo G. Hertlein and Allyn G. Smith of the California Academy of Sciences kindly assisted in the identification of some of the Pleistocene mollusks and made available for study the collections at that institution. A. Myra Keen of Stanford University gave helpful advice on the taxonomy of several Pleistocene mollusks and provided access to the collections at Stanford University.

J. E. Schoellhamer visited the island each field season to help measure and sample stratigraphic sections, aided in the compilation of the regional geology, and made valuable contributions to other parts of the report. R. L. Harbour began the geologic mapping and 
supplied the basic data for differentiation of the stratigraphic units in the Eocene rocks. R. F. Yerkes provided the petrographic data on the igneous rocks, and Robert M. Norris did the petrographic studies, mechanical analyses, and heavy-mineral separations of the Eocene sandstone samples. A. O. Woodford reviewed the results of the laboratory studies of the rock samples and offered pertinent suggestions on their mineralogy. M. C. Israelsky furnished the description of the methods used for possible zonation of the Eocene Foraminifera and determined their probable age and correlation.

\section{HISTORY AND CULTURE}

San Nicolas Island probably was first sighted by Europeans in 1542 or 1543 during the exploration of the California coast by Juan Rodriquez Cabrillo, although the records of the voyage contain no specific mention of the island (Henshaw, 1879, p. 312; Davidson, 1889, p. 76 ). Sixty years later, on December 6 , 1602, Sebastian Vizcaíno's launch Tres Reyes anchored off the island on the feast day of Saint Nicholas of Myra, patron of sailors, travelers, and merchants. The crew gave the island the name in common usage today (Gudde, 1949, p. 311) but erroneously charted its size and position (Davidson, 1889, p. 76).

The early Spanish explorers found a relatively culturally advanced group of Indians living on the island. The many extensive kitchen middens, indicate that a fairly large aboriginal population inhabited the island for many centuries before the arrival of the Spaniards. According to Kroeber (1953, p. 623-635), the San Nicoleño who dwelled on the island were a division of the coastal Gabrielino tribe, derived from Shoshonean stock. The island was known as Gha-las-hat by the Indians, but the meaning of the name has been lost. In 1811 a group of Kodiak Indians from Sitka was landed on the island by Captain Whittemore, from the Boston fur-trading firm of Boardman and Pope, for the purpose of sea otter hunting. During their 2year stay the Kodiaks killed most of the male inhabitants of the island. The remaining San Nicoleño lived undisturbed until 1836 when Captain Isaac Williams, collector of the port of San Pedro, at the request of the Spanish mission authorities, removed all but one native to the mainland (Schumacher, 1877, p. 52). The one exception, the famous "lost woman of San Nicolas," lived in complete isolation on the island for 18 years before she was found by Captain George Nidever and taken to Santa Barbara (Hardacre, 1880, p. $657-664)$.

During the 2 centuries following Vizcaino's voyage of exploration little is recorded of the history of San
Nicolas Island; but many white men, chiefly sealers and sea otter hunters from American and Russian fur-trading ships, doubtless disembarked on the island early in the 19th century. French, English, Russian, and American exploring and survey parties that sailed past the coast of southern California during the period 1787 to 1849 may have sighted San Nicolas Island, but Davidson $(1889$, p. 68$)$ made the following remark regarding the lack of knowledge of the island region prior to 1851:

Lntil the Coast Survey first examined in detail the islands lying off the main, nothing accurate was known of their number, peculiarities, extent, or position. Upon all maps, as of recent date as 1850, an island called San Juan was laid down, and upon a map of the Republic of Mexico, compiled in the Inited States. and dated $\mathbf{1 8 4 7}$, we find no less than twelve large islands, the positions and extent of which are most grotesquely erroneous.

Occasional visits, most of them before 1900, were made by several archeologists and naturalists (Schumacher, 1877; Cessac, 1882; Yates, 1896; Hemphill, 1901; Lowe, 1903 ; Comstock, 1946, p. 95-96, 97-98; Meighan and Eberhart, 1953). As early as the 1870 's, Chinese abalone fishermen used the island as a source of supply of the large mollusks for export to China (Schumacher, 1877, p. 48). The island reportedly was laid out in lots by an enterprising and optimistic realtor in 1886 (Holder, 1910, p. 283), but the Ventura County records contain no mention of the subdivision.

San Nicolas Island was acquired from the government by the U.S. Navy in 1933 for use as a gunnery range; in 1940, the U.S. Army assumed control of the government-owned land. Jurisdiction of the island was transferred back to the U.S. Navy in 1946 .

The earliest geologic description of San Nicolas Island appears in a brief report by J. G. Cooper of the Geologic Survey of California (Cooper in Whitney, 1865 , p. 184). In a discussion of the southern California island group, Cooper mentions the unfossiliferous sandstone that dips $25^{\circ}$ on the north side of San Nicolas Island, and he describes the terrace deposits and their fossil content, the Indian shell mounds, and the lack of vegetation.

Both Paul Schumacher, an archeologist (1877, p. 46) and George Davidson, of the U.S. Coast Survey $(1889$, p. 75-78), note the sandstone bedrock, the dunecovered areas on the west end of the island, and the sparse vegetation that resulted from overstocking of sheep.

Stephen Bowers, in another early geologic report (1890, p. 57-59) describes the flat upper surface of San Nicolas Island, the underlying sandstone and its apparent structure, the molluscan fauna from the lowest terrace, and the dune sands. 
Only two reports, both unpublished, describe the geology of San Nicolas Island in detail. L. E. Kemnitzer ${ }^{1}$ gives a generalized account of the structure, stratigraphy, and age correlation of the sedimentary rocks on the island. R. M. Norris ${ }^{2}$ presents a detailed oceanographic study of the shelf areas around San Nicolas Island and a brief discussion of the island geology. Both reports contain reconnaissance geologic maps. A short description of the underwater geology off the north coast of the island, together with a reproduction of Norris' geologic map, is contained in a paper on geologic diving techniques by Menard and others (1954).

\section{CLIMATE, VEGETATION, AND WHLLIFE}

Under average meteorological conditions a layer of cool, moist marine air envelopes San Nicolas Island from sea level to an altitude of about 2,500 feet, resulting in the formation of low clouds or fog in all but the coolest winter months. Fog occurs during all months of the year but is more frequent and more dense during the spring and summer.

The prevailing westerly winds frequently reach velocities of 35 to 55 miles per hour during the winter and attain periodic velocities of 45 miles per hour during the summer.

The Navy has maintained detailed weather records for the island since 1948, and their temperature and rainfall data for an 8-year period from 1948 to 1956 are summarized below.

Monthly mean temperatures (in degrees Fahrenheit):

\begin{tabular}{|c|c|c|}
\hline Janue & 53 & July ..... \\
\hline Feb & 52 & August_.... \\
\hline & 54 & September..... \\
\hline & 55 & October \\
\hline & 56 & November \\
\hline une & 58 & December. . \\
\hline
\end{tabular}

Maximum temperature observed: $105^{\circ} \mathrm{F}$.

Minimum temperature observed: $33^{\circ} \mathrm{F}$.

Average annual rainfall: 6.61 inches.

The vegetation on the island is limited to low grasses and shrubs, some of which were identified by K. S. Norris (Department of Zoology, University of California, Los Angeles, 1950) and R. M. Norris as salt grass (Distichlis spicata); bur-weed (Franseria chamissonis) ; coast goldenbush (Haplopappus venetus vernoniodes); Australian salt bush (Atriplex semibaccata); coyote brush (Baccharis pilularis consan-

\footnotetext{
1 Kemnitzer, L. E., 1933, Geology of San Nicolas and Santa Barbara Islands, southern California : California Inst. Technology, unpublished M.S. thesis, 45 p.

2 Norris, R. M., 1951, Marine geology of the San Nicolas Island region, California: California Univ., Los Angeles, unpuolished Ph.D. thesis, $124 \mathrm{p}$.
}

guines), the largest native plant now growing on the island; seascale (Atriplex leucophylla); rabbitfoot (Polypogon monspeliensis); silver lupine (Lupinus albifrons); and giant coreopsis (Coreopsis gigantea). Cattail (Typha sp.) grows along some of the watercourses in which seepage occurs throughout the year. Cockerell (1938, p. 19) lists two forms of plants (Lotus ornithopsiss and Convolvulus macrostegius) found on the island that presumably do not occur on the mainland. Holder (1910, p. 322) states that Mrs. Blanche Trask collected about one hundred species of plants on the island, many of which were new; and Bowers $(1890$, p. 60) makes reference to a statement by Captain George Nidever of Santa Barbara that a part of the island was covered by trees and brush before 1850.

Resistant white calcareous sandstone casts of roots of large shrubs or trees as well as numerous shells of land snails, now rarely found living, indicate that Recent vegetation was at one time dense over much of the island.

The only land vertebrates now living on the island are the San Nicolas Island fox (Urocyon littoralis dickeyi), the San Nicolas deer mouse (Peromyscus maniculatus exterus), and the island night lizard (Xantusia riversiana). The subspecies of mouse live only on San Nicolas Island, but other subspecies. lives on Santa Catalina, San Clemente, and Santa Barbara Islands (Cockerell, 1938, p. 12). The same species of lizard also lives on San Clemente and Santa Barbara Islands (Cockerell, 1938, p. 14). Both the mouse and lizard may have reached San Nicolas Island on floating debris, in Indian canoes, or perhaps were even carried by large birds. The fox, however, is a variant of a group of foxes which inhabit the other islands, and like the mouse, shows some evidence of evolutionary change subsequent to its arrival on San Nicolas Island. Presumably the foxes were introduced by the Indians at an early date, for their remains often are present in the kitchen middens. Large wild dogs, undoubtedly imported by the Indians, were numerous on the island as late as 1850 (Schumacher, 1877, p. 48; Hardacre, 1880 [1950, p. 11]) but were last reported to be present only 3 years later (Bowers, 1890, p. 59).

Large herds of the California sea lion (Zalophus californianus) inhabit the southwest shore between Vizcaino Point and Seal Beach. The elephant seal (Mirounga angustirostris), harbor seal (Phoca vitulina), and the Steller sea lion (Eumetopias jubata) occasionally appear on the beaches in the same area. The rare Guadalupe fur seal (Arctocephalus townsendi) has recently been observed on the island (Ingles, 1954, 
p. 137). Sea otters (Enhydra lutris) were plentiful around the island before 1800 , but they are now extinct locally.

Many species of sea birds and several species of land birds, including ravens and bald eagles, were observed on and around San Nicolas Island, but no attempt was made to identify individual forms. In about 1900, Professor Joseph Grinnell found more than 20 species of birds on the island during a short visit (Holder, 1910, p. 249).

\section{REGIONAL STRUCTURE AND STRATIGRAPHY}

The eight islands off the coast of southern California afford the only surface exposures of the rocks that may lie beneath the sea over an area of about 31,000 square miles between the mainland and the continental slope. The following excerpt from Emery (1954, p. 107) describes the limitations and the precautions necessary for study of this predominantly submarine area :

* * * here the unknown geology far exceeds the known. Because of the relative inaccessibility of the submarine area. each new fact gained is expensive in terms of both time and effort, and thus it receives more attention and interpretation than an equivalent new fact of land geology. Care must constantly be exerted to avoid over-exploitation of the facts, and this can be done mainly by judging what is reasonable in terms of knowledge borrowed from the geology of the adjacent land.

Any correlation, other than age, of the rocks on San Nicolas Island with those of the mainland and other nearby islands should be made with reservations, for inadequately known geologic structures of great magnitude certainly are present on the sea floor between the island the the southern California coast. Inasmuch as San Nicolas Island is the most seaward of the island group, a correct interpretation of the rocks exposed there is important in further understanding the structural features and stratigraphic correlation of the rocks lying on the floor of the continental borderland off southern California.

About 55 miles north and northwest of San Nicolas Island are four northern Channel Islands. These are, from west to east, San Miguel, Santa Rosa, Santa Cruz, and the Anacapa Islands (pl. 1). Marine sedimentary rocks of Cretaceous, Paleocene, Eocene, and Miocene age crop out on San Miguel Island where they attain a total thickness of approximately 20,000 feet (Kennett in Redwine, and others, 1952). Intrusive igneous rocks of Miocene age cut the older sedimentary rocks, and volcanic breccias and flows are interbedded with the Miocene sedimentary rocks on San Miguel Island. Both Santa Rosa and Santa Cruz Islands have exposures of marine sedimentary rocks of Paleocene, Eocene, and Miocene age together with volcanic rocks of Miocene age (Bremner, 1932, p. 14; Kew, 1927; T. L. Bailey, 1954). Sedimentary rocks of Cretaceous age occur in the subsurface on Santa Cruz Island, and it is on this island that the only metamorphic rocks in the northern group are exposed. Pre-Cretaceous chlorite phyllites and sericite schists intruded by quartz diorite occur in the central part of Santa Cruz Island (Rand, 1931, p. 215; Bremner, 1932, p. 13-16). The Anacapa Islands are composed of volcanic rocks of Miocene age as mapped by T. L. Bailey (1954), but interbedded schist breccia has recently been reported from the volcanic sequence (Scholl, 1959).

This northern group of islands has east-trending structures and is the partially submerged continuation of the Santa Monica Mountains on the mainland to the east. The Santa Monica Mountains and the northern Channel Islands form the southwest margin /of the structural and geomorphic Transverse Ranges Province (Reed, 1933, p. 9-11). Shepard and Emery (1941, p. 47) and Corey $(1954$, p. 74$)$ suggest that Santa Cruz Island is bounded on the south by a fault scarp, indicating that the island has been elevated and the submarine area to the south down-dropped. This inferred fault is presumably the seaward continuation of the major zone of faulting along the south side of the Santa Monica Mountains.

South of the northern group of Channel Islands and the Santa Monica Mountains the gross structural features trend northwest, and this area may be considered the partially submerged part of the structural and geomorphic Peninsular Range Province (Jahns, 1954, p. 29). The index map (pl. 1) shows the orientation of the islands and the numerous northwest-trending submarine escarpments that presumably indicate the general structural pattern of this part of the offshore area. The reconnaissance geologic map (fig. 1) also illustrates this general trend by the distribution of the Cenozoic igneous and sedimentary rocks and the Mesozoic (?) metamorphic rocks dredged or cored from the sea floor off southern California. Large-scale faults about which little is known also are present in this seaward extension of the Peninsular Range Province (Shepard and Emery, 1941, fig. 18, p. 47; Norris, p. $59-69 ;^{3}$ and Corey, 1954, p. 74 ).

Santa Barbara and San Clemente Islands are composed almost entirely of volcanic rocks of middle Miocene age (Smith, 1898; Olmsted, 1958; and Kemnitzer). ${ }^{4}$ Small outcrops of marine sedimentary rocks of middle Miocene age are interbedded with the volcanic rocks on San Clemente Island. The type and age of the rocks beneath these islands are unknown.

\footnotetext{
${ }^{3}$ See footnote 2, p. 4.

4 See footnote 2, p. 4.
} 


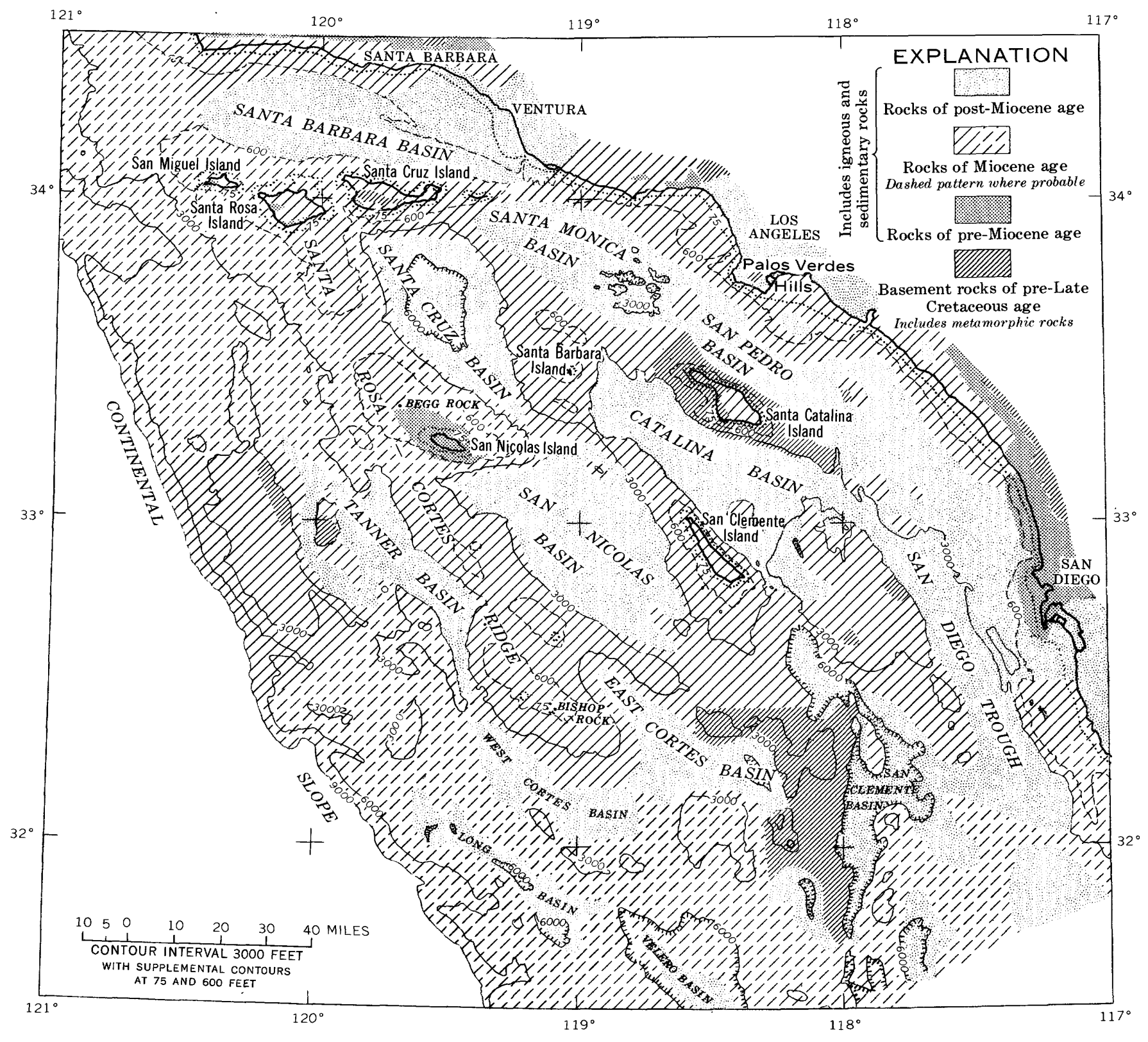

Figurn 1.-Reconnaissance geologic map of the sea floor off southern California. (After Emery, 1954, fig. 1, p. 108.)

Cortes and Tanner Banks (pl. 1), with reported minimum water depths of 2 and 9 fathoms, respectively, presumably were islands during part of late Pleistocene time, or perhaps even in Recent time. The shallow-water areas on both banks are underlain by basaltic rocks of Miocene(?) age, and the shelf areas are composed of calcareous sedimentary rocks of probable middle Miocene age (Holzman, 1952, p. 100, 103, and 105-106).

Santa Catalina Island, 52 miles east of San Nicolas Island, has extensive outcrops of volcanic rocks interbedded with small exposures of clastic limestone of Miocene age in the central part of the island (E. H. Bailey,
1954). The southeast end of the island is composed of quartz diorite porphyry that may be of Tertiary age (ibid., map explanation). Most of the western part of the Santa Catalina Island contains outcrops of glaucophane schist and related metamorphic rocks not found in the basement rocks on Santa Cruz Island. Woodford (1924) called these metamorphic rocks the Catalina metamorphic facies of the Franciscan series. Reed (1933, p. 31) suggested that the metamorphic rocks underlying the San Nicolas Island area are of the Franciscan type. Along the southwest margin of the Los Angeles basin and in the Palos Verdes Hills, sedimentary rocks of Miocene age rest directly on Catalina schist 
basement (Woodring and others, 1946, p. 12-13; Schoellhamer and Woodford, 1951). Emery and Shepard $(1945$, p. 435$)$ report the presence of "unfossiliferous sandstone and chert similar to Franciscan (Jurassic?) rocks of the mainland" from a submerged area 30 miles southwest of San Nicolas Island, west of Tanner Basin, but no glaucophane-bearing rocks are reported from this area. Holzman (1952, p. 117) found no evidence of sodium-amphibole rock debris in the sedimentary rocks bordering Cortes and Tanner Banks. Areas of crystalline rock similar to the Catalina schist that are further removed from San Nicolas Island are shown on the regional geologic map south and east of San Clemente Island (fig. 1).

The part that the structural highs of supposed preCretaceous rocks at Catalina Island, Santa Cruz Island, and west of Tanner Basin may have played in the depositional history of the younger sedimentary rocks in the region of San Nicolas Island is unknown. Dredging and coring of the sea floor in the vicinity of San Nicolas Island have yielded no clastic fragments derived from basement rocks similar to those found on Catalina Island; however, small tabular fragments of glaucophane schist occur in the older terrace deposits of Pleistocene age, suggesting a nearby source area for this rock type. Whether these schist fragments were derived from a sedimentary formation resembling the San Onofre breccia of middle Miocene age (Woodford, 1925) that now may be concealed on the sea floor near the island or from old structural highs of sodium-amphibole schists is conjectural.

Begg Rock, 8 miles northwest of San Nicolas Island, is presumably the remnant of a rhyolite dike or flow (Kemnitzer, p. 6) ${ }^{5}$ that may correlate with rlivolite flows and agglomerates of Miocene age exposed on the south side of Santa Cruz Island (Bremner, 1932, p. 22-24) and on San Clemente Island (Olmsted, 1958 , p. 62). An elongate shoal about 2 miles long lying 33/4 statute miles northeast of Army Camp Beach on the north coast of San Nicolas Island is composed of diabase (Norris, p. 37-39). ${ }^{6}$ The structural and stratigraphic relations of these nearby offshore igneous bodies to the sedimentary rocks on the island shelf area are not known, but they may represent extensive intrusions along large faults.

\section{GEOMORPHOLOGY}

GEOMORPHIC SETTING OF THE ISLAND PLATFORM

San Nicolas Island is on the south edge of a broad, relatively flat salient submarine ridge that protrudes east from the main trend of Santa Rosa-Cortes sub-

\footnotetext{
5 See-footnote 1, p. 4.

- See footnote 2, p. 4.
}

marine ridge (fig. 1). Santa Rosa-Cortes Ridge extends southeast from Santa Rosa Island to Cortes Bank, a distance of approximately 130 statute miles. The ridge rises to 907 feet above sea level on the San Nicolas Island salient and to within 15 feet of the surface at Bishop Rock (fig. 1) on Cortes Bank. Most of the crest of the ridge lies less than 600 feet below sea level. Santa Cruz Basin, with depths in excess of 6,000 feet, lie directly north of San Nicolas Island and is one of the deepest closed basins in the continental borderland off southern California. South of the island, depths of about 3,900 feet occur in the westernmost part of San Nicolas Basin, which deepens to 6,000 feet to the southeast toward San Clemente Island. Westward from San Nicolas Island, the island platform joins Santa Rosa-Cortes Ridge at a depth of less than 600 feet. Eastward, the island salient ends abruptly at the edge of a trough more than 3,000 feet deep which connects Santa Cruz and San Nicolas Basins.

San Nicolas Island is surrounded by a sloping shelf, the outer edge of which has an average depth of 350 feet. South of the island the edge of the shelf is nowhere more than a mile from shore, but the northern shelf is, in marked contrast, more than 6 miles wide. As a consequence, the southern shelf has an average gradient of about 350 feet per mile $\left(3^{\circ} 50^{\prime}\right)$ and the northern shelf a gradient of only 60 feet per mile $\left(0^{\circ} 40^{\prime}\right)$. The slopes beyond the shelves also differ in steepness; on the south side of the island the gradient is about 1,000 feet per mile $\left(11^{\circ}\right)$ and on the north side about 600 feet per mile $\left(61 / 2^{\circ}\right)$. The gradients of the shelf and slope on the south side of the island presumably indicate the presence of an eroded fault. scarp relatively near the insular shelf. Earthquake epicenters located in this area support the hydrographic evidence for a large fault (Clements and Emery, 1947).

The surface of the shallow shelf adjacent to San Nicolas Island is reasonably flat when considered as a unit, but when examined in detail, as was done by the diving teams during 1955 and 1956 , much local irregularity is observed that is not apparent from the bathymetric contour pattern. Nearly vertical cliffs 40 feet or more high were found on a few dives, as well as many overhanging ledges formed by differential erosion of soft siltstone interbedded with resistant sandstone. Although some faults were observed by the diving teams, they account for only a small part of the local irregularity of the sea floor. Most of the relief presumably is due to differential erosion by stream and wind at a eustatic lower stand of sea level. A prominent bench at a depth of 330 feet has been re- 
corded on echo-sounding profiles made across the deeper part of the shelf area. Other less prominent benches occur at depths of 55 to 65 feet, 110 to 130 feet, 160 to 180 feet, and at 230 feet (Norris, p. 3940). ${ }^{7}$ Additional submerged terraces at intervening depths and down to nearly 400 feet are plotted by Emery (1958, p. 54, fig. 11). Furthermore, a relatively steep break in slope is present at the shelf edge, starting at about 60 fathoms (Uchupi ; ${ }^{8}$ Emery, 1958, p. 54, fig. 11) and may demark the lowest stand of sea level in late Pleistocene time.

U.S. Coast and Geodetic Survey chart 5101 and chart I in Shepard and Emery (1941) show many small submarine canyons cutting the slope on the north side of the island and at least two canyons crossing the south slope. All these canyons are concentrated at the east end of the island platform. Echo-sounding profiles (Norris, p. 40) ${ }^{9}$ show numerous small gullies not indicated on any existing charts. These small features are common to many submarine slopes and are not unique at San Nicolas Island. These gullies apparently do not cut into the bedrock surface and may be due to erosion of the slope sediments by turbidity currents.

\section{GENERAL FEATURES OF THE ISLAND}

From the south and southwest, San Nicolas Island appears as a bold, highly dissected escarpment that attains an altitude of 600 to 900 feet for a distance of approximately 6 miles. The elongate ridge that forms the crest of the escarpment lies $3 / 4$ to $11 / 4$ miles from the shoreline on the south side of the island. The highest point on the island is only slightly more than 1 mile from the south coast. From the north and northeast, the island presents an entirely different aspect. A sequence of wave-cut terraces that ranges in altitude from near sea level to the high part of the island lends a steplike appearance to the broad, relatively gentle north slope. The ridge that forms the crest of the island lies slightly more than 2 miles from the north shoreline. A relatively steep slope 400 to 500 feet high forms the east face of the island, but the west end is characterized by a rather gentle slope from sea level to an altitude of 600 feet over a distance ranging from $3 / 4$ to nearly $21 / 2$ miles.

\section{TERRACES}

The most striking physiographic feature on the north slope of San Nicolas Island is the nearly continuous sequence of marine terraces. A brief descrip-

\footnotetext{
${ }^{7}$ See footnote 2, p. 4.

${ }^{9}$ Uchupl, Elazar, 1954, Submarine geology of the Santa Rosa-Cortes Ridge: Southern California Univ., unpublished M.S. thesis, p. 9. See footnote 2, p. 4 .
}

tion of the terraces by Upson (1951, p. 442) lists altitudes for several prominent platforms. Both Kemnitzer (1936) ${ }^{10}$ and Norris (p. 15-18) ${ }^{11}$ include statements about the main terrace platforms and their estimated altitudes, which roughly match those given in this report. Seven fairly well defined terraces were recognized on the north and east parts of the island during the fieldwork for the present report. (See table 1). In addition to the well-defined terraces, seven other poorly defined platforms are present on the higher central upland surface of the island north of Jackson Hill. Except for the two lowest terraces, which extend discontinuously along much of the southern coast, only a few remnants appear either along the steep streamdissected southern escarpment or in the sand-covered western part of the island. The higher terraces are difficult to trace for more than half a mile owing to destruction by extensive gullying, to burial of the platforms by deposits of aeolian sand or slope wash, and to the merging of the ancient sea cliffs where terrace cutting on later levels destroyed parts of the shorelines of preceding levels. Below the 400-foot contour on the north side of the island the slope is steep and scarred by extensive landslides, and the terrace platforms that may have been cut in this area cannot be definitely recognized. A few additional minor benches may exist on the north side, but they are impossible to follow because of slope-wash cover.

The terrace platforms vary considerably in width; the 100 -foot terrace is a few hundred feet to nearly $1 / 4$ mile wide. Wave-abraded platforms between the 400 - and 800 -foot contours attain their greatest widths in the northeastern part of the island where several prominent benches (including some intervening poorly developed benches) underlie gently sloping nonmarine terrace surfaces $1 / 4$ to $3 / 4$ mile in width and 5 miles in length. Vertical distances between successive terrace platforms also vary considerably; the most abrupt and prominent ancient sea cliff between platforms is displayed along the northeast side of the island between the 120 - and 400 -foot contours. Presumably the cutting of the 100 -foot terrace in this area destroyed the intervening levels by shoreward erosion of the sea cliff. The other ancient sea cliffs on the island exceed a height of 50 feet at only a few places.

It is evident that the terraces represent surfaces of marine planation because all the principal platforms locally are covered at their eroded outer edges by thin deposits of fossiliferous calcareous sand and gravel 6 inches to 10 feet thick that are very similar to de-

\footnotetext{
10 See footnote 1, p. 4.

11 See footnote 2 , p. 4 .
} 
TABLE 1.-Designation, altitude, fossil localities, and description of terraces on San Nicolas Island

[See pl. 2]

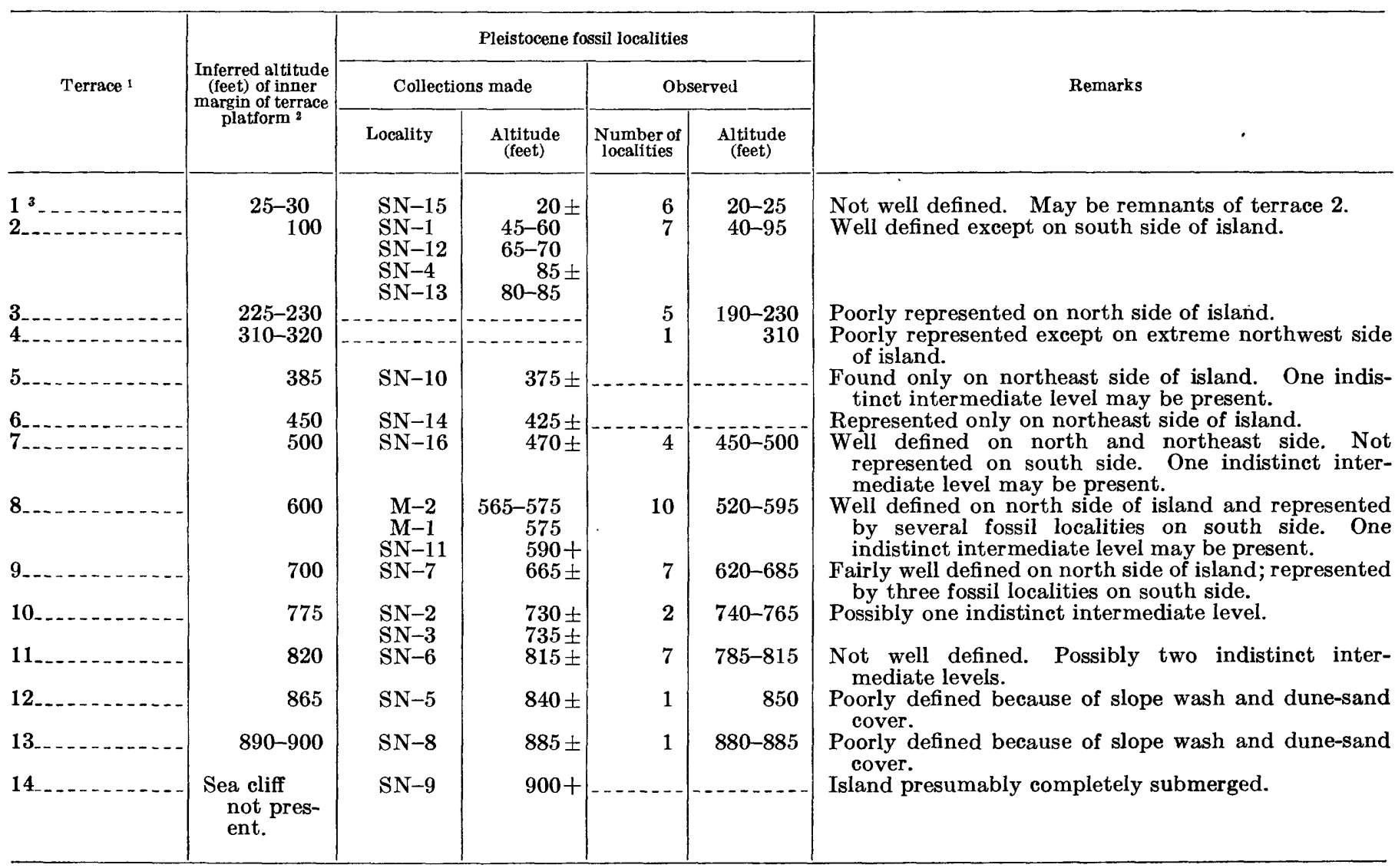

1 Does not include indistinct or minor levels.

- Base of sea cliff or shoreline angle.

6-foot bench not included.

posits now accumulating on the shallow sea floor north and west of the island. The fossiliferous deposits characteristically grade shoreward into beach and dune remnants that originated at the time of the terrace cutting. The great thickness of the shallow marine, beach, and coastal dune deposits on many of the platforms suggests that these shorelines may have been cut by a retreating sea (Davis, 1933, p. 1055-1056).

Similar wave-cut terraces are prominent features at many places along the coast of southern California and on the other islands. These marine terraces are described in numerous reports dealing with various areas throughout the coastal region (Lawson, 1893; Smith, 1900; Davis, 1933; Putnam, 1942, p. 739-748; Hertlein and Grant, 1944, p. 17-22; Woodring and others, 1946, p. 113-116; Upson, 1949, 1951; Putnam, 1954; Emery, 1958, p. 39-60). Supposed wave-abraded platforms that now lie below sea level on the shelf area around San Nicolas Island are described by Norris (p. 39-40) ${ }^{12}$ and Emery (1958, p. 54, fig. 11)

12 See footnote 2 , p. 4. and are referred to in the section of this report titled "Geomorphic setting of the island platform." These submerged platforms are cut into the island shelf to depths of 400 feet.

Comparison of the altitudes reported for the terraced areas elsewhere in southern California with those of San Nicolas Island show only general agreement for the lower levels and very little agreement with the higher levels. Errors in measurement of terrace altitudes are common and can be attributed to several causes: variable seaward gradients of the wavecut platform, cover of marine and nonmarine sediments, differential erosion of the seaward margins of higher terraces by successively lower stands of sea level, warped or faulted platforms, and lateral changes in altitude due to variation in resistance to erosion of the bedrock. Because all these factors were not considered by some of the earlier workers on San Nicolas Island and elsewhere in California and as reliable reference points other than shoreline angle (which itself varies in altitude) are ordinarily absent, terrace correlation often is erroneous. 
The general lack of correlation between the higher emergent terrace levels from area to area and the great altitude of the higher platforms demonstrate that the cutting of these terrace levels in southern California cannot be ascribed entirely to eustatic change of sea level but must be attributed in part to local differential uplift of individual terraced blocks. It is probable that eustatic changes of sea level took place during some such local uplifts with the result that wave-abraded platforms cut during various eustatic sea levels may have been superimposed on platforms eroded into emerging or submerging fault blocks. Relative sea-level changes of this nature possibly would result in terraces that are not synchronous but that lie at the same altitude in widely separated areas and would also account for the partial lack of correlation of terrace altitudes in different terraced areas along the mainland coast. However, the apparent regional correlation in the depth of shallow submerged terraces off southern California (Emery, 1958, p. 42-44), the relatively good correlation of the altitudes of the lowest emergent terraces at some localities along the coast (Davis, 1933, p. 1066-1070; Upson, 1951, p. 427434 ; Hoskins ${ }^{13}$ ) and the relation of both to worldwide levels (Shepard and Wrath, 1937, p. 45; Zeuner, 1945, p. 252), all indicate that the abrading of these platforms may have occurred during eustatic changes in sea level, followed by slight deformation. Even though the low emergent platforms along the mainland coast of southern California are locally tilted a few degrees in the Ventura area (Davis, 1933, p. 1052-1053; Putnam, 1954, p. 45) and near Newport Beach, and up to $26^{\circ}$ in the Palos Verdes Hills (Woodring and others, 1946 , p. 109), and though there is evidence for slight regional seaward warp of the submerged shelf edge at the rate of 160 feet per 100 miles (Emery, 1958, p. 44-46), tilting of the emergent terrace platforms of San Nicolas Island cannot be demonstrated. Two minor faults noted in the terrace deposits at altitudes of 650 and 840 feet have no pronounced effect on the gradient of the underlying platforms. However, the terraced areas on the island may not be of sufficient extent to measure a slight regional warp such as that discussed by Emery.

Conclusive evidence is lacking for the existence of a land bridge that may have connected San Nicolas Island to the late Pleistocene peninsula now occupied by the northern Channel Islands. Bathymetric data indicate that the lowest definite submerged terrace

\footnotetext{
${ }^{13}$ Hoskins, C. W., 1957, Paleoecology and correlation of the lowest emergent Callfornia marine terrace, from San Clemente to Halfmoon Bay : Stanford Univ., unpublished Ph.D. thesis.
}

platform (shelf edge) was cut at depths of less than 430 feet on Santa Rosa-Cortes Ridge between Begg Rock and Santa Rosa Island (Emery, 1958, p. 44). However, a 13-mile span of ocean floor that lies at depths greater than 430 feet transects this ridge halfway between Santa Rosa Island and San Nicolas Island. The maximum recorded depth in this saddle is 245 fathoms (1,470 feet) (Uchupi, p. 10), ${ }^{14}$ which is far deeper than any supposed submerged terrace platforms of late Pleistocene age. The presence of the diminutive fox of San Nicolas Island often is cited as evidence for a land bridge, but it is more probable that the animal was imported by the aborigines as part of their food supply long after the fox had evolved to its dwarfed form on the northern Channel Islands. Both the white-footed mouse and night lizard could have been transported to San Nicolas Island on floating debris derived from mainland floods, in Indian canoes, or on the ships of otter hunters. The presence of fossil terrestrial snails in the 100 -foot terrace deposit at locality SN-1 presumably can be attributed to the rafting of these forms to the island on flood debris from the mainland. Neither floral nor faunal evidence can be cited for the presence of a land bridge before the cutting of the supposed oldest terraces on San Nicolas Island because the highest points on the island are mantled by marine deposits that indicate complete submergence in late Pleistocene time.

The well-preserved third upper molar of a normalsize mammoth reported to have been collected by Mrs. Blanche Trask on San Nicolas Island is in the vertebrate collection of the Paleontology Department at the University of California, Berkeley. Examination of the fossil tooth revealed uncemented sand grains and Recent(?) shell fragments in the tooth crevices, suggesting that it was found in a kitchen midden on a coastal dune rather than in a shallow marine terrace deposit. As Mrs. Trask did considerable artifact collecting from the kitchen middens on San Nicolas Island sometime before 1910 (Meighan and Eberhart, 1953 , p. 112 , table 3 ), it is possible that she found the tooth in such a deposit. The size of the tooth also implies that the mammoth could not have been a migrant dwarf from the northern Channel Islands. All vertebrate material collected from the terrace deposits at San Nicolas Island is poorly preserved, worn, caliche encrusted, and contains only aquatic-bird and marine-mammal bones. Presumably the lone occurrence of a single elephant tooth can be attributed to its transport to the island by the aborigines as a curio or ceremonial object.

\footnotetext{
14 See footnote 8 , p. 8 .
} 


\section{DRAINAGE}

No permanent streams are present on San Nicolas Island and the intermittent streams contain running water only for a short period after moderately heavy rains which occur infrequently during the winter. During heavy rainstorms the larger steep ravines may contain rapidly flowing water to a depth of 1 to 3 feet. Much of the mud- and silt-laden water is discharged into the ocean, which remains discolored to more than a mile offshore for several days. Springs flow throughout the year in a number of the deeper canyons where the stream bed intersects large faults, but the runoff from the springs is negligible. Elsewhere springs appear along the contact between the bedrock and Quaternary deposits in a few drainage systems.

The steep south side of the island is highly dissected by stream channels that have a dendritic drainage pattern. Badland topography has been developed at a number of places on this slope but is best displayed in exposures of the thick siltstone unit one-half mile south of Jackson Hill. The drainage system is poorly dereloped on the north side of the island, and on the west end most of the stream channels in the dune-covered areas do not reach the coast. The mouths of all the stream channels are accordant with sea level, and there is no evidence of alluviation due to drowning or of incising resulting from a relative drop in sea level.

\section{DUNES}

Active and partly stabilized longitudinal dunes oriented parallel to the direction of the prevailing westerly winds blanket much of the western third of San Nicolas Island. Most of the large active dunes are concentrated in the arcuate area between Vizcaino Point and the 200-foot contour between Seal Beach and Thousand Springs. Several large active dunes extend to the vicinity of hill 905 and upper Tule Creek (pl. 3). The prevailing westerly and northwesterly winds transport sand from the western coastal area onto and across the higher upland surfaces of the island where roughly parallel fingerlike projections of active and partly stabilized sand protrude east and southeast as far as upper Mineral Creek. A few older stabilized longitudinal dunes reach southeast on the high terrace platforms beyond Jackson Hill and Celery Creek. A strip of small isolated active dunes derived in part from adjacent beaches extends the length of the north and south shorelines along the outer margin of the lowest emergent terrace. On the steep parts of the south side of the island the progress of the migrat- ing sand is impeded by the deep canyons that dissect the slope.

The dimensions of individual dunes are difficult to record because of the rapid shifting of the active dunes and the lack of definite separation between stabilized or partly stabilized dunes. Many of the large Recent dunes on the west end of the island are 50 feet or more high and may attain a length of 1,600 feet. Extremely long dunes are present on the higher terrace platforms but few are more than 10 feet high. Sand Dune Canyon contains an extensive isolated dune, more than 100 feet high and approximately 600 feet long, composed of sand that was transported across the high upper surface of the island.

Wind-scoured troughs several feet deep and exhumed soil surfaces formed on older dune deposits are common features in many partly destroyed dune areas.

Study of aerial photographs of the island taken in 1943 and 1955 indicate that the dunes on the higher terrace platforms are periodically stabilized and reactivated and that the area covered by dunes is gradually diminishing in size.

\section{LANDSLIDES}

Several extensive landslides up to a mile in width occur along the steep slope on the north side of San Nicolas Island. Only one slide of comparable size is present on the south side of Jackson Hill. The easternmost large landslide, northwest of Coast Guard Beach, is about three-quarters of a mile wide and consists of relatively unbroken strata derived from a sandstone unit and a siltstone unit. A part of this large broken block has moved downslope a distance of approximately 100 yards, forming a sizeable rubblefilled crevice between its rearward margin and the stable bedrock. Eolian sand has completely filled this opening at the western extremity. of the slide and forms a surface continuous with the nonmarine cover on the 385-foot terrace, indicating that the slide took place before much of the terrace cover was deposited. Most of the other large slides along the north coast show the same features along their inner margins.

Along the north side of the island, the bedrock dips seaward about $10^{\circ}$ to $15^{\circ}$. When relative sea level was about 100 feet higher, during a part of late Pleistocene time, waves undercut the base of the slope; thus, only a slight triggering action is necessary to set the landslide blocks in motion downdip on siltstone bedding planes. Because of the relatively unbroken nature of the slide debris some of the landslides are difficult to recognize. 


\section{BEACHES}

Short sandy pocket beaches separated by broad headlands of thick-bedded sandstone occur along much of the coastline of San Nicolas Island. Relatively wide sand beaches up to 1 mile in length break the continuity of the pocket beaches and intervening headlands at Dutch Harbor, 1 mile east of Dutch Harbor, along the spit, at Army Camp Beach, and at 2 places between Thousand Springs and Vizcaino Point. Along the extreme western part of the south coast and near BM-21 on the northwest coast, metamorphic cobble or sandstone-boulder beaches, rather than the usual sandy beaches, are present. Elsewhere along the shoreline only thick-bedded sandstone is continuously exposed, locally for distances of half a mile or more. Where the sandstone is jointed or rests on easily eroded rocks, wave erosion has excavated deep, narrow channels and caverns, and in other places has created an inclined rocky shelf by eroding the rock along bedding planes that dip seaward. A sea cliff 5 to 30 feet high borders the inner margins of the beaches and the seaward edges of the rocky headlands along most of the island coast.

The most prominent beach feature on the island is the roughly triangular sandspit that in 1955 extended about 1 mile beyond the east end of the island proper; a submerged bar continued eastward beyond the exposed portion of the spit for about an additional mile. Sand has been deposited on the spit by waves and winds to about 16 feet above mean sea level. A study of the spit (Norris, 1952, p. 224-228) indicates that it is subject to considerable change both in outline and position from year to year as the result of the variability of wave force. The sand comprising the spit seems to have been transported in part by strong longshore currents that move southeast along the north side of the island; waves and currents on the south side, on the other hand, move mainly west and erode the spit. Winds from the northwest blow obliquely across the spit and carry much sand from the north side to the south. The outline of the sand spit in 1955 showed no marked change in shape or size from the 1943 survey, but its position was slightly different; the spit had shifted south, possibly because of the construction of the breakwater at Coast Guard Beach in 1951-52.

\section{STRATIGRAPHY}

\section{CONCEALED ROCKS}

The thickness and lithology of the rocks underlying San Nicolas Island are not known. The principal difficulty in predicting the subsurface stratigraphy on San Nicolas Island is the lack of detailed geologic data in the adjacent submerged or island areas that can be directly correlated with the geologic features on San Nicolas Island. Such a lack of information is quite unlike geologic studies on the mainland, where surface and subsurface information in adjoining areas can be used to evaluate the structural and sedimentational picture of the region under observation. However, rocks exposed on other islands, seismic data obtained offshore, and rock samples collected from the sea floor in the San Nicolas Island area provide some evidence as to the lithology and thickness of sedimentary rocks that may lie beneath the rocks of Eocene age exposed on the island.

Approximately 15,000 feet of sedimentary rocks of Cretaceous, Paleocene, and Eocene age is exposed on San Miguel Island (Kennett in Redwine and others, 1952). Most of this thick sedimentary sequence is older than that exposed on San Nicolas Island, but some of the rock types are remarkably similar, suggesting the same source area for the sediments.

Seismic data obtained by Raitt $(1949$, p. 1915) indicate that approximately 3 kilometers $(9,840$ feet) of sedimentary rock rests on the basement rocks in Santa Cruz basin between San Nicolas Island and Santa Cruz Island. The sedimentary rocks exposed on the sea floor in Santa Cruz Basin are probably of Miocene age or younger, as shown on the reconnaissance geologic map of the sea floor (fig. 1). About $21 / 2$ miles northeast of Begg Rock (pl. 1 and fig. 1), which lies 8 miles northwest of San Nicolas Island, a northwesttrending seismic profile indicates an approximate sediment thickness of 1.7 kilometers (5,600 feet) and a gentle northwest dip in the bedrock (Raitt, oral communication, 1955). Norris (p. 46-47) describes ${ }^{15}$ sedimentary-rock samples of probable Eocene age dredged from the ocean bottom in the vicinity of the southeast end of seismic profile and between Begg Rock and the island. Emery's map (fig. 1) shows rocks of questionable Miocene age on the sea floor in the seismicprofile area. Samples of shale from the sea floor along the Santa Rosa-Cortes Ridge between Begg Rock and the saddle in the ridge 12 miles to the north have yielded foraminiferal faunas that range in age from early to late Miocene (Uchupi p. 22-27). ${ }^{16}$ Norris also notes the presence of sedimentary rocks resembling the Monterey shale of Miocene age along the 50-fathom contour north of San Nicolas Island. Unfortunately, it is not known whether sedimentary strata older than the Eocene crop out on the shelf area northwest of the island, nor is the location and nature of the EoceneMiocene contact known.

\footnotetext{
15 See footnote 2, p. 4 .

${ }^{16}$ See footnote 8, p. 8 .
} 
In June 1955 the U.S. Geological Survey conducted an aeromagnetic survey of San Nicolas Island and vicinity. The flight consisted of a traverse from the Palos Verdes Hills across Santa Barbara Island to San Nicolas Island, 11 traverses across San Nicolas Island, and a return traverse across Santa Catalina Island to the Palos Verdes Hills. Concerning this survey, R. W. Bromery (written communication, 1956) states:

The magnetic pattern over San Nicolas Island shows only the regional gradient and suggests that there is little igneous rock in the general area. There is no significant anomaly from which a depth to basement can be calculated.

The total thickness of sedimentary rocks exposed on and beneath San Nicolas Island is estimated to be about 5,000 feet, based mainly on Raitt's preliminary seismic work north and east of Begg Rock. However, the lithology and age of sedimentary rocks that may lie beneath the oldest unit exposed on the island are not known, and any correlation with the Cretaceous and early Tertiary sedimentary rocks exposed on the northern Channel Islands would be misleading. The nature of the basement rock on which these unknown sedimentary rocks rest is even more obscure. On the basis of the inferred regional geology, it is possible that the basement rocks are a correlative of the Catalina schist.

\section{GENERAL FEATURES OF THE EXPOSED ROCKS}

The stratigraphic section of sedimentary rock exposed on San Nicolas Island consists primarily of alternating sandstone and siltstone beds that attain a thickness of approximately 3,500 feet. Fossils indicate that the sedimentary bedrock, of which neither the base nor top is exposed, is of middle to late Eocene age. Several small igneous dikes of Miocene(?) age intrude the sedimentary rocks near the southeast end of the island. Unconformably overlying the rocks of Eocene age are unconsolidated marine terrace deposits and windblown sand of Pleistocene age. Large areas of Recent dune deposits and lesser amounts of beach sand and alluvium obscure the older sedimentary rocks over much of the island.

Thirty stratigraphic units have been differentiated in the rocks of middle to late Eocene age. These units have not been named formally because the section is incomplete. They are numbered consecutively, with unit 1 the oldest; the relative position and gross lithology of each unit is shown on the map explanation (pl. 3) and on the stratigraphic sections (pl. 5). Each unit is differentiated primarily on the basis of its predominant lithology, relative strategraphic position, nature of the upper and lower contacts, and thickness.
The description of grain size and sorting is based on field determination and not on the results of laboratory analyses. It is difficult to distinguish any single sandstone or siltstone unit from another on the basis of lithology alone, because there is no apparent change in the mineral content from unit to unit and distinctive marker beds are lacking throughout the section. A few siltstone units isolated by faults are differentiated on the basis of foraminiferal faunas. In addition to the numbered units, five informal rock units of middle to late Eocene age are indicated by the letters $\mathrm{A}, \mathrm{B}, \mathrm{C}, \mathrm{D}$, and $\mathrm{E}$ on the geologic map. The lettered zones either contain individual mappable lithologic units of unknown stratigraphic position that have been isolated by Quaternary deposits or faults, or they are composed of strata that have not been differentiated with respect to the known stratigraphic sequence.

Detailed subdivision of the stratigraphic section on San Nicolas Island was necessary to determine the amount and direction of displacement on numerous intersecting faults and to correlate the lithologic units in adjoining fault blocks.

The sedimentary rocks of Quaternary age have been subdivided into terrace deposits, dune sand, and alluvium on the geologic map (pl. 3). The deposits on the terrace platforms include shallow marine sediments, old beach sands and dune deposits, and a cover of slope wash and dune remnants. Partly cemented eolian sands of Pleistocene and Recent age are not differentiated from active dunes on the geologic map, and aboriginal shell mounds are included with these dune deposits. Limited exposures of stream outwash composed of silt, sand, and rubble and Recent beach deposits that consist of sand, gravel, and rubble are combined and are shown as Quaternary alluvium on the geologic map.

\section{TERTIARY SYSTEM}

EOCENE SERTES

\section{GENERAL FEATURES OF THE EOCENE ROCKS}

The rock sequence of middle to late Eocene age exposed on San Nicolas Island is composed of four principal rock types that are the lithologic basis for the subdivision of the stratigraphic section into mappable units. These rock types are thick-bedded sandstone, thin-bedded siltstone, thinly interbedded sandstone and siltstone, and conglomerate or conglomeratic mudstone.

Sandstone units are the most numerous in the Eocene sequence and have a combined thickness nearly equal to that of the other lithologic units. In general, the sandstone units consist of light-gray thick-bedded fine- 
to medium-grained micacous arkosic sandstone (arkosic sandstone as defined by Williams, Turner, and Gilbert, 1954, p. 310-315). The clastic fragments are predominantly angular and poorly sorted to moderately well sorted, and the grain size ranges from very fine to very coarse within a single bed. Scattered tabular fragments of siltstone frequently occur in thin, nonpersistent beds in many of the sandstone units, and many are twisted or curved, suggesting that the siltstone was only semiconsolidated during transportation and deposition. A few of the sandstone beds exhibit cross-lamination, current ripple marks, or a variety of small-scale sedimentary structures, but well-defined graded bedding is rare. Examination of a few current-bedding structures in several sandstone units indicates current movement from north to south. Large calcareous concretions that lie in individual beds or in a sequence of beds are commonly present within the sandstone units. Many sandstone beds are separated by sandy siltstone partings or by very thin siltstone beds that commonly contain carbonaceous material. Mollusk(?) borings and tracks and worm(?) trails and tubes frequently mark the upper surfaces of some sandstone beds. When weathered, the thick sandstone beds form prominent yellowish-gray outcrops; many are cavernous or honeycombed. Nearly vertical joints that intersect at about $90^{\circ}$ occur in most of the thick-bedded sandstone units. Secondary calcite fills many small joints or faults in the sandstone units, and most exposures show varying degrees of discoloration from ferruginous stain. Some of the sandstone units vary markedly in thickness, and several lens out completely.

Several distinct mappable units composed predominantly of blue-gray siltstone with minor amounts of mudstone and claystone occur in the stratigraphic sequence. Interbedded with the siltstone are very thin beds of limy fine-grained sandstone a few inches thick that weather yellowish gray or reddish brown and that emphasize the bedded appearance of the siltstone units. Ordinarily the siltstone exhibits a hackly or conchoidal fracture and may contain thin streaks of concentrated carbonaceous material and scattered small pyritiferous concretions. Gypsum fills many small joints and fractures in the rock. The siltstones weather olive gray and usually form gentle slopes beneath the cliff-forming sandstone units.

Another distinct set of units composed of interbedded sandstone and siltstone is made up of a sequence of alternating beds that individually are too thin to be delineated on the geologic map. The percentage of sandstone and siltstone in these units is approximately equal The light-gray sandstone is generally fine to medium grained, weathers to yellowish gray, and much of it displays small-scale structures and current ripple marks. The siltstone contained in the interbedded sandstone and siltstone units is somewhat sandy and weathers to light gray or olive gray. In places, claystone and mudstone are interbedded with the siltstone. Many units composed of interbedded sandstone and siltstone are lenticular, and the ratio of sandstone to siltstone and the thickness of the bedding may vary. The thin-bedded sandstone and siltstone units are deeply eroded where they occur between thick-bedded sandstone units, but they form relatively prominent outcrops where locally present within siltstone units.

The only unit on San Nicolas Island containing massive conglomerate is composed primarily of lenticular beds of pebbles and cobbles interbedded with sandstone and breccia. Two conglomeratic mudstone and sandstone units that commonly display slump structures occur at widely separated places in the straitgraphic sequence. These two units are not extensively exposed but are easily eroded to relatively gentle slopes strewn with pebbles and cobbles.

The same rock types that occur on San Nicolas Island are present on the submarine shelf adjacent to the northwest end of the island and are tentatively correlated with the exposed sequence on the basis of general lithology and Foraminifera content. Brief notes on the rock types observed or collected on the submarine shelf are shown in table 7 .

In the areas where submarine ridges rise above the general level of the sea floor and where rocky shoals project close to or above the surface of the water, the bedrock generally is thick-bedded sandstone that usually supports a heavy kelp growth. Areas in water less than 100 feet deep that form depressions or broad troughs on the sea floor and that support little or no kelp growth usually indicate siltstone bedrock. Kelp apparently cannot maintain holdfasts in the softer, finer grained rocks, and only the smaller varieties of algae grow over the submarine outcrops of siltstone and mudstone. Conglomerate beds and interbedded sandstone and siltstone beds usually have a variable amount of kelp cover, depending on the amount of current action and the induration of the rocks.

The combined thickness of the stratigraphic sections measured in the middle to late Eocene rocks exposed on San Nicolas Island is slightly less than 3,500 feet (see pl. 5), but lateral variation in the thickness of individual units undoubtedly alters this figure in different areas. Sea-floor outcrops of Eocene sedimentary 
rocks extend several miles northwest and east of the island (Norris, p. 46, 48), ${ }^{17}$ but the structure and areal extent of these rocks are not definitely known. The probable repetition of this sea-floor section by faulting and folding leads the authors to postulate a minimum outcrop thickness of 5,000 feet for the Eocene rocks exposed on San Nicolas Island and the surrounding shelf area.

\section{DESCRIPTION OF MAPPED UNITS}

UNIT 1

The oldest stratigraphic unit in the unnamed sandstone, siltstone, and conglomerate sequence is known only from exposures on a wave-cut bench at the southwest edge of an up-faulted block near Vizcaino Point. Thick-bedded medium-grained arkosic sandstone constitutes most of the unit. Thin, 2- to 4-inch beds of fine-grained sandstone occur at intervals in the middle part of the outcrop, and a lenticular bed of cobble conglomerate approximately 1 foot in maximum thickness is exposed near sea level at the west edge of the outcrop. Curved and twisted siltstone fragments 2 to 6 inches in length are also scattered through a few feet of sandstone near the extreme western part of the outcrop. Large elongate calcareous concretions occur in a few of the thick-bedded sandstone strata near the top of the unit. As the base of unit 1 is not exposed above the low-tide line, a minimum thickness of about 30 feet is estimated ( $p l .5$ ). No fossils were found in the unit, but because the lithology is similar to that of overlying units and because there is no unconformity at the top of the unit, it is considered to be Eocene in age.

$$
\text { UNIT } 2
$$

Unit 1 is overlain by a cobble-bearing mudstone and sandy siltstone unit which is designated unit 2 and which is found only in the up-faulted block on the southwest side of Vizcaino Point. The well-rounded pebbles and cobbles contained in the mudstone are not sufficiently abundant to warrant usage of the term "conglomerate." Massive olive-gray mudstone is the predominant lithology, but it grades into sandy siltstone and fine-grained sandstone. The pebbles and cobbles range in maximum diameter from about $1 / 2$ inch to approximately 8 inches, with an average diameter of about 3 inches, and are composed mainly of hard, dense dark-gray, greenish-gray, and brownishgray metavolcanic and metasedimentary rocks. Scattered angular and tabular fragments of sandstone and siltstone, with maximum dimensions of about 2 feet, occur in the unit. Bedding in unit 2 is either indistinct

\footnotetext{
17 See footnote 2, p. 4 .
}

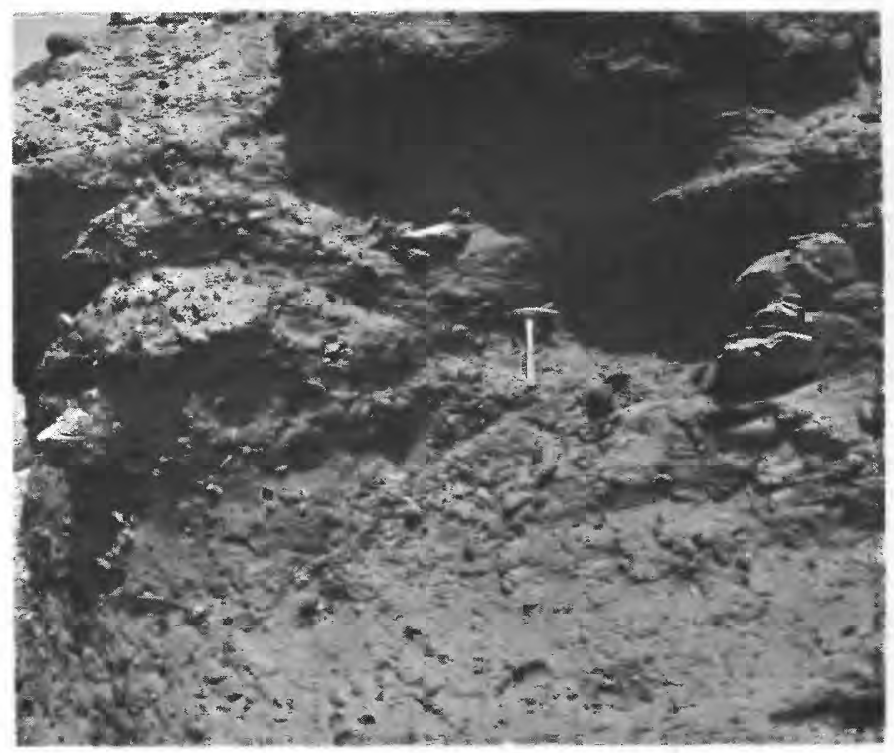

Figure 2.-Conglomeratic mudstone of unit 2 exposed in a sea cliff near the west end of the island. The large sandstone block at the right center is a clastic fragment. The pebbles and cobbles are predominantly metamorphic rocks derived from an unknown source.

or absent, and there is no apparent preferred orientation of the cobbles (fig. 2). Exposures in the wavecut bench and sea cliff indicate a minimum thickness of 25 feet for the unit. Because faults bound units 1 and 2 on the northwest and southeast, their lateral variation in lithology and thickness is unknown. The base of unit 2 is sharply defined and shows no evidence of channeling; Quaternary deposits cover the upper contact of the unit. Widely scattered oyster-shell fragments and a few worn and incomplete gastropods are the only fossils in unit 2. Several incomplete specimens comparable to Turritella lawsoni indicate an Eocene age for the unit.

An extensive cobble-bearing siltstone that resembles unit 2, and that may correlate with it, occurs on the sea floor at offshore stations 51, 84, 86, 87 and 89 (pl. 4; table 7).

The well-rounded cobbles of unit 2 may possibly represent material reworked from older conglomerates, or they may have been transported a great distance before deposition. Conglomerates of Cretaceous and Paleocene age exposed on San Miguel Island, 63 miles to the northwest, contain similar rock types that show the same degree of roundness.

\section{UNIT 3}

I thick-bedded sandstone sequence that crops out a short distance southeast of Vizcaino Point and that presumably overlies unit 2 in the same area, is designated unit 3. It consists primarily of yellowish-gray 
medium-grained micaceous, arkosic sandstone that contains scattered coarse-grained rock fragments. Individual beds within unit 3 are separated by thin siltstone or fine-grained sandstone beds a few inches thick. Small lenticular beds of metavolcanic cobbles occur at two places in the upper part of the unit. Large elongate to nearly spherical resistant calcareous concretions, 1 to 10 feet in the long dimension, are common in some of the thick beds. The base of unit 3 is either covered by dune sand or occurs below low tide, but a minimum thickness of 115 feet is estimated for unit 3. Its lateral variation in thickness and lithology is unknown.

\section{UNIT 4}

Unit 4 contains the only massive conglomerate exposed on San Nicolas Island Eight-tenths of a mile southeast of Vizcaino Point, this unit consists of three rock types: conglomerate, fine- to coarse-grained sandstone, and breccia (fig. 3). The conglomerate contains a silty sandstone matrix with well-rounded pebbles and cobbles that range in maximum diameter from $1 / 4$ inch to 10 inches, with an average diameter of about $2 \frac{1}{2}$ inches. The cobbles and pebbles are predominantly hard, dense gray, greenish-gray, and brownish-gray metavolcanic and metasedimentary rocks that are unlike any basement rocks exposed on the other islands or the nearest parts of the mainland. Scattered among the metamorphic pebbles are small subangular clastic fragments of siltstone and finegrained sandstone that were probably locally derived. Imbrication of the cobbles in some beds suggests a

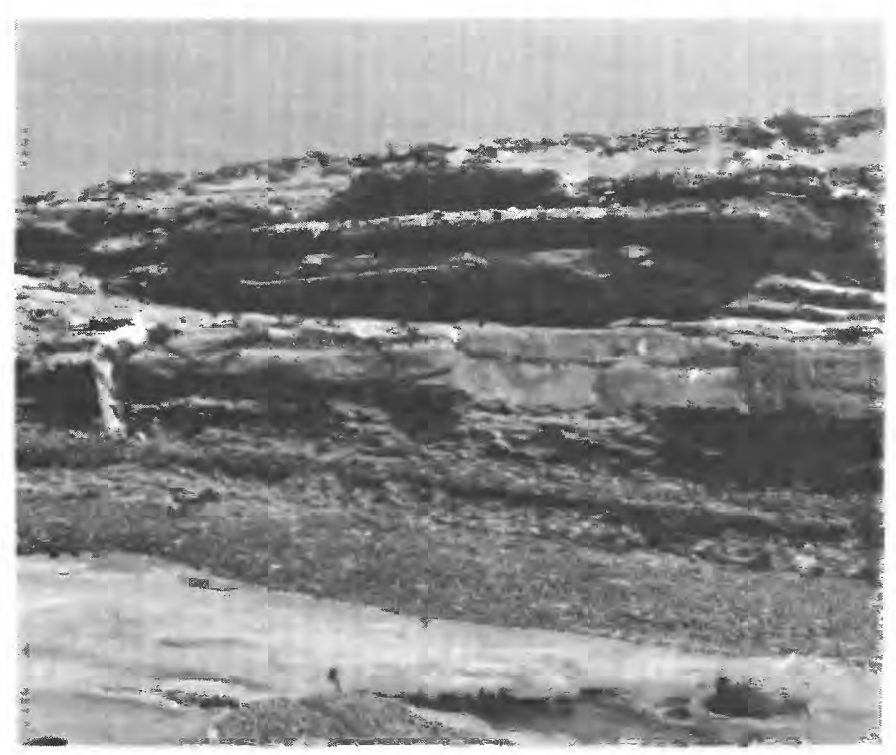

Figure 3.-Lenticular beds of conglomerate, breccia, and sandstone in unit 4 near the west end of the island. Imbrication of the cobbles in the lowest bed, although not apparent in this photograph, suggests current movement from left to right.

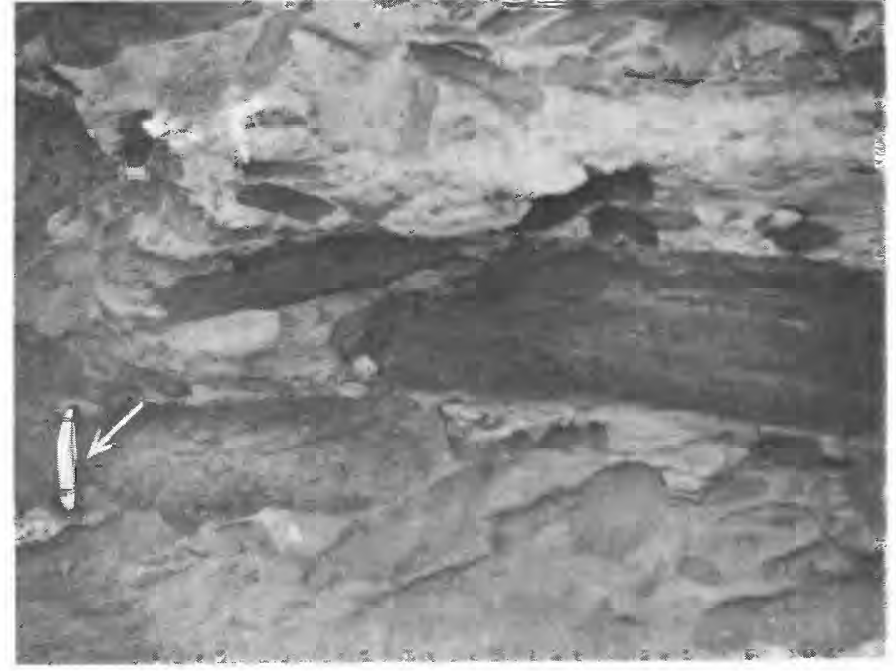

FIGCRE 4-Clastic fragments of siltstone and mudstone embedded in a matrix of sandstone contained in unit 4. Presumably the tabular fragments in the breccia were locally derived.

south-moving current at the time of deposition, and the roundness of the metamorphic cobbles may indicate reworking from older conglomerates. The irregular lenticular conglomerate beds range in thickness from a few inches to 5 feet. The interbedded sandstone is medium to coarse grained and poorly sorted to moderately well sorted. It resembles the sandstone of unit 3 in general appearance, but contains poorly defined graded beds of pebble conglomerate and coarse-grained sandstone near the top of the unit. Associated with the massive conglomerate beds are intraformational breccia beds 1 to 3 feet thick. Angular slabs of siltstone, mudstone, and fine-grained sandstone constitute most of the larger clastic fragments within a coarsegrained sandy matrix (fig. 4). A few blocks and boulders of coarse-grained sandstone and cobble-bearing mudstone are distributed through the breccia. All the constituents in the breccia closely resemble the older Eocene sedimentary rocks exposed elsewhere on the island and were probably locally derived. The maximum thickness of unit 4 is approximately 20 feet (fig. 35). The conglomeratic parts of the unit thin northwest from the thickest exposed section in the sea cliff west of hill 192, but the thickness of the entire unit seems to remain constant. The upper contact of unit 4 is gradational. Fragments of oyster shells are commonly found in the breccia sequences of unit 4 and are the only fossils recovered from the unit.

A sandy conglomerate observed by divers at station 25 is lithologically similar to unit 4 .

The conglomeratic parts of unit 4 bear a striking resemblance to conglomerates of Cretaceous and Paleocene age observed on the west coast of San Miguel 
Island. Possibly the source area for the conglomerates in unit 4 was the same, or perhaps the well-rounded pebbles and cobbles of unit 4 were reworked from older conglomerates like those exposed on San Miguel Island.

$$
\text { UNIT } 5
$$

Unit 5 is one of two exceptionally thick sections of sandstone in the unnamed sandstone and siltstone sequence on San Nicolas Island. The best exposures are found along the wave-cut bench about $1 \frac{1}{4}$ miles southeast of Vizcaino Point and at the tip of the point. The narrow submarine ridge that extends northwest from Vizcaino Point probably is formed in part by strata correlative with unit 5. In general, unit 5 is composed of thick-bedded, poorly sorted to moderately well sorted medium-grained arkosic sandstone. The grain size of the sandstone ranges from fine to coarse within a single bed without apparent graded bedding. Thin beds of intercalated sandstone and siltstone occur in unit 5 near the base and top and are as much as 10 feet thick. Concentrations of mica flakes and carbonaceous material appear in some beds and delineate the bedding. Large elongate to nearly spherical calcareous concretions like those present in unit 3 occur in some of the thick beds. Fresh outcrops are light gray but weather to yellowish gray. The estimated maximum thickness of unit 5 is approximately 445 feet. The upper contact is gradational.

$$
\text { UNIT } 6
$$

Unit 6 is not only the thickest siltstone unit in the sedimentary sequence but also is the thickest individual unit exposed on the island. The one completely exposed section of unit 6 occurs along a tidal bench about $1 \frac{1}{2}$ miles southeast of Vizcaino Point where it can be examined only during low tide. The predominant lithology in unit 6 is thin-bedded blue-gray clayey to sandy siltstone that breaks with a hackly or conchoidal fracture. Some claystone and mudstone are interbedded with the siltstone. Beds of light-gray, very fine grained micaceous sandstone a few inches thick are commonly interbedded with the siltstone near the base of the unit but become less numerous near the middle and top. The thin lime-cemented sandstone beds weather to yellowish-gray or brownish-gray resistant bands that emphasize the bedding in the unit. Small amounts of carbonaceous material are concentrated in a few thin beds throughout the unit, and secondary gypsum and calcite fill many small joints as well as fractures along bedding planes. Small darkgray pyritiferous concretions 1 to 3 inches in diameter occur sporadically throughout the siltstone. Unit 6 weathers to olive-gray slopes beneath the cliff-forming beds of unit 7 (fig. 5). The single complete exposure of unit 6 , measured along the tidal bench southeast of Vizcaino Point, has a stratigraphic thickness of 596 feet (pl. 5). A local minor unconformity exists at the top of the unit in the Sand Dune Canyon area. Foraminifera are common throughout the unit, but no megafossils were found.

The broad semicircular trough that lies between the offshore rocky shoals and the west end of the island has a bedrock floor composed primarily of siltstone that has yielded Foraminifera that correlate with those of unit 6. The thickness and lithology of this belt of siltstone on the sea floor also indicates that it is correlative with unit 6 .

Lenticular beds composed mainly of thick-bedded sandstone are locally present within unit 6 in upper Sand Dune Canyon, in several fault blocks south of Jackson Hill, and in the area north of Dutch Harbor. These discontinuous sandstone lenses appear at about the middle of unit 6 and are collectively designated unit $6 \mathrm{a}$ on the geologic map and structure sections. The lenses consist of a sequence of sandstone beds 6 inches to 15 feet thick interbedded with thin alternating lenticular beds of sandstone and siltstone. The lithologic character and bedding of the sandstone in this unit compare closely with those of the upper part of unit 7. A maximum thickness of 150 feet is estimated for the lenticular sandstone bodies in unit 6 southwest of Jackson Hill and north of Dutch Harbor. One specimen of Acila decisa, a small pelecypod restricted to strata of Eocene age in California, was found in the lenticular sandstone beds at locality $\mathrm{E}-3$.

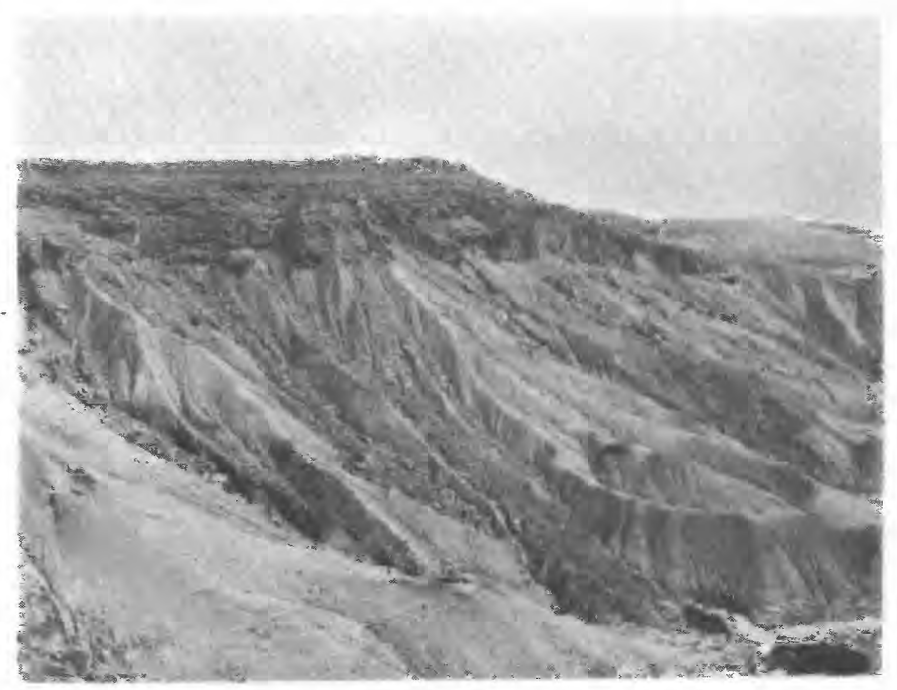

Fiqure 5.-Slope-forming siltstone beds of unit 6 overlaln by cliffforming sandstone beds of unit 7 along the east wall of Sand Dune Canyon. The canyon wall at this point is approximately 450 feet high. 
Foraminifera are present in the interbedded siltstone beds.

UNIT 7

The cliff-forming thick-bedded sandstone sequence that everywhere overlies the siltstone of unit 6 on San Nicolas Island is designated unit 7. The unit is best exposed on the east side of Sand Dune Canyon, in the area immediately southeast of Jackson Hill, and in the cliffs three-quarters of a mile north of Dutch Harbor. The predominant rock type is light-gray medium- to coarse-grained arkosic sandstone containing varying amounts of biotite and muscovite. Carbonaceous material is scattered through a few beds and often serves to delimit the bedding. Individual grains in the sandstone are angular and may range in size from very fine to very coarse. Large elongate calcareous concretions averaging 2 to 4 feet in diameter are common throughout the unit and occur in distinct beds. The unit is usually thicker bedded near the base, where some beds attain a thickness of 20 feet (fig. 6 ) ; toward the top, the sandstone is thinner bedded and contains increasing amounts of interbedded siltstone. A siltstone marker bed that attains a thickness of 15 feet (pl. 5) is present close to the base of unit 7 in the fault block across which section 4 was measured and immediately northwest of Dutch Harbor. Unit 7 normally forms prominent yellowish-gray outcrops that display cavernous or honeycomb weathering (fig. 7). Slump bedding is a common sedimentary feature throughout the unit and usually occurs in beds 6 inches

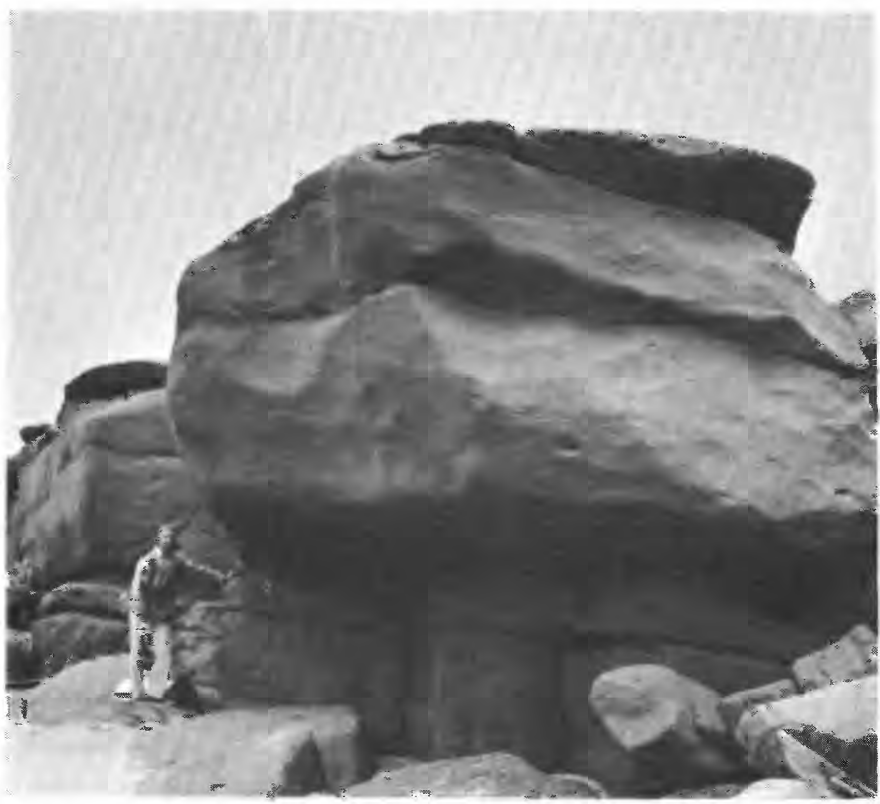

Figdre 6.-Thick-bedded sandstone typical of the lower part of unit 7 exposed in a sea cliff about one-third of a mile southeast of the mouth of Sand Dune Canyon.

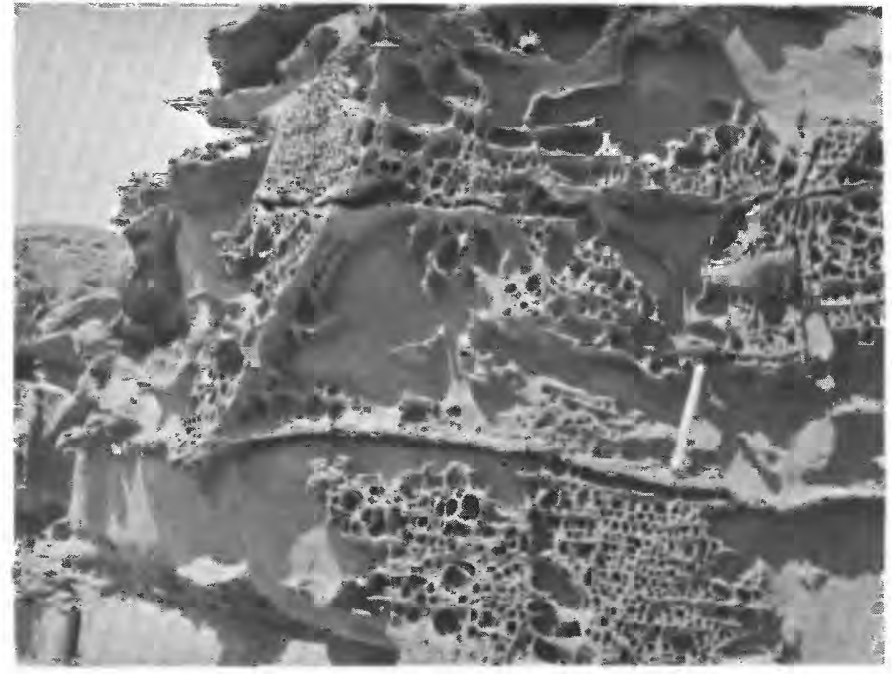

Figure 7.-Honeycomb weathering exhibited on the windward surfaces of sandstone beds in unit 7 near Dutch Harbor. The resistant network contains a higher percentage of calcium carbonate cement than the surrounding hollow surfaces.

to 3 feet thick. Calcite fills some narrow joints in the sandstone, and ferruginous stain colors much of the weathered rock reddish brown. Between Sand Dune Canyon and Dutch Harbor, unit 7 maintains a relatively constant thickness of 125 to 150 feet. In the small fault blocks about three-quarters of a mile northwest of Seal Beach the unit thins to approximately 80 feet but thickens again to the west and north. Locally a minor unconformity separates unit 7 from unit 6 . Exposures on the east side of upper Sand Dune Canyon exhibit progressive truncation of unit 6 . To the east the lower contact is sharply defined and appears to be conformable. The upper contact of unit 7 is gradational. Oyster fragments were found in the thick sandstone beds, and Foraminifera were collected from the thin siltstone beds near the top of the unit.

Many of the resistant thick-bedded sandstone beds found by the divers near the exposed rocky shoals $11 / 3$ miles west of Vizcaino Point may be repeated fault blocks of unit 7 .

UNIT 8

Unit 8 is a sequence of alternating sandstone and siltstone beds (fig. 8) that individually are too thin to be shown on the geologic map. Unit 8 is best exposed near the coast south of Jackson Hill and in the fault blocks north of Dutch Harbor. Sandstone and siltstone beds are distributed approximately equally throughout the unit, although the ratio of sandstone beds to siltstone beds may vary at different localities or in different parts of the unit. The sandstone is predominantly fine to medium grained, micaceous, fairly well sorted, and commonly concretionary. A 
few sandstone beds contain less mica than is ordinarily present in the thick-bedded sandstone units. Individual sandstone beds in unit 8 attain a maximum thickness of 20 feet but usually range in thickness from a few inches to several feet. Cross-lamination occurs in some sandstone beds, and small amounts of carbonaceous material are usually present in both the sandstone and siltstone. Much of the gray siltstone that is interbedded with the sandstone is sandy or clayey and forms gentle olive-gray slopes between the resistant yellowish-gray sandstone beds. Thin beds of limy fine-grained sandstone usually are present in the

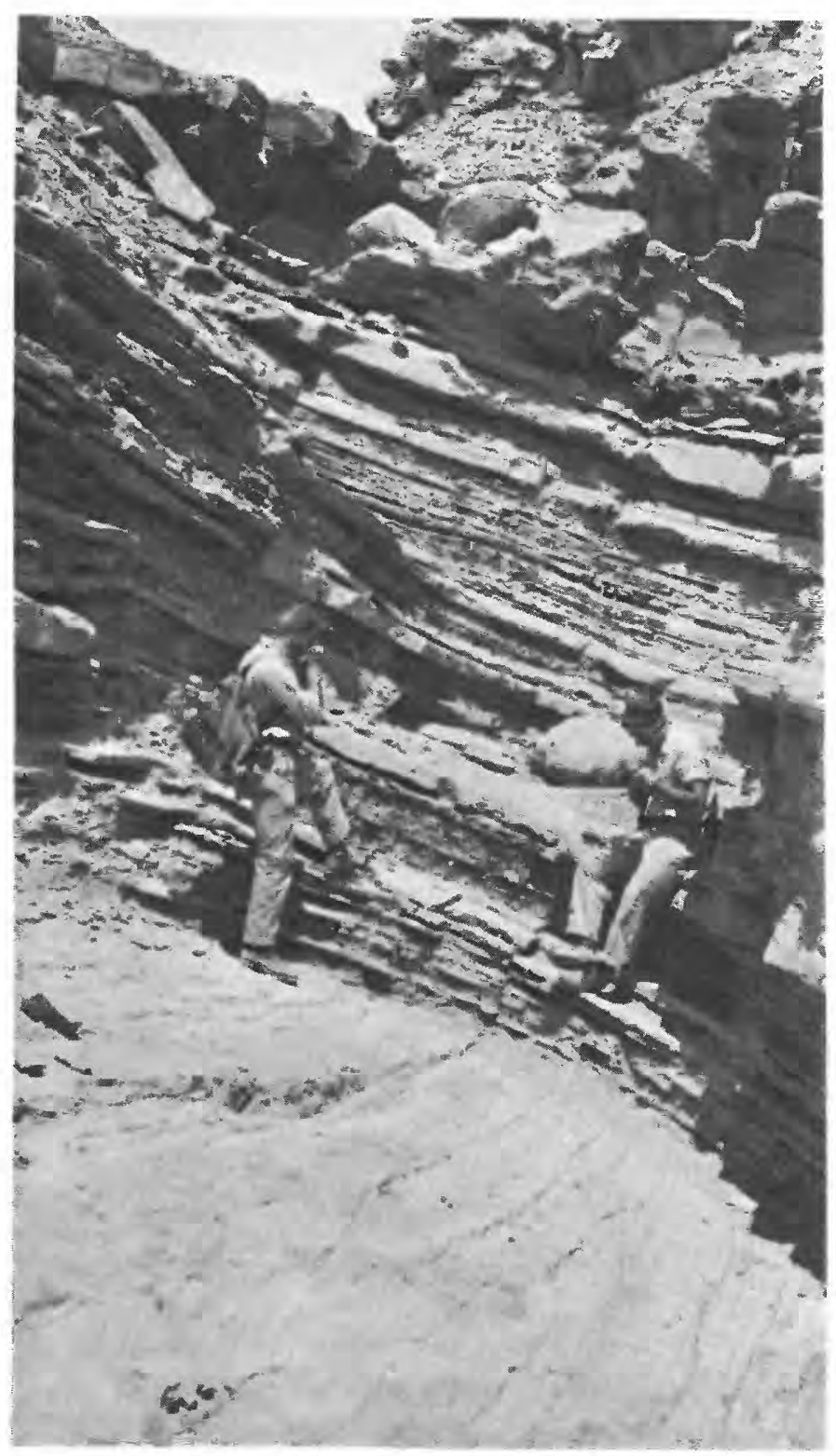

Figure 8.--Interbedded sandstone and slltstone in unit 8 exposed in a deep ravine southwest of Jackson Hill. The thick-bedded sandstone in the upper part of the photograph is included in unit 8 . siltstone strata. Individual beds are commonly lenticular and some thin beds lens out within a distance of a few feet. In several fault blocks northeast of Dutch Harbor the upper part of unit 8 is interbedded with the overlying unit. Unit 8 generally maintains a relatively constant thickness of 125 to 155 feet.

UNIT 9

Unit 9 is best exposed north of Dutch Harbor in the fault block across which stratigraphic section 6 was measured. Unit 9 is a thick-bedded concretionary sandstone sequence that, in general lithologic character, resembles unit 7 . The sandstone is usually micaceous, indistinctly bedded, and poorly sorted. Thin siltstone beds occur near the top of the unit but are subordinate to the sandstone beds. Ordinarily, unit 9 weathers to prominent yellowish-gray outcrops. Marked lateral variation in lithology and thickness is typical of unit 9 ; a quarter of a mile northeast of Dutch Harbor it grades laterally into, and intertongues with, units 8 and 10 and is not present in some fault blocks in this area. In stratigraphic section 6 (pl. 5), unit 9 attains a maximum thickness of 72 feet and grades upward into the overlying unit.

UNIT 10

Unit 10 is a conglomeratic mudstone and sandstone sequence that is lithologically similar to unit 2. However, the cobbles are generally widely dispersed, and only in the type area, about a quarter of a mile northeast of Dutch Harbor, are they as abundant as the cobbles in the pebbly mudstone of unit 2 . Nowhere in unit 10 are the larger clastic fragments as closely packed as in the massive conglomerate of unit 4. The cobbles are well rounded and range from less than 1 inch to about 8 inches in maximum diameter in the type area. No cobbles have been found in several fault blocks in the area between Seal Beach and Jackson Hill; here a correlative unit is designated 10a on the geologic map. The predominant rock types are gray, greenish-gray, and brownish-gray dense metavolcanic and metasedimentary rocks. The matrix ranges from mudstone to poorly sorted medium-grained sandstone that is ordinarily olive gray in fresh exposures and locally contains large angular fragments of sandstone and siltstone. Bedding in the conglomeratic parts of unit 10 is usually indistinct or absent, but many large-scale slump structures are present. The unit is not resistant to erosion and forms rounded slopes or subdued outcrops between unit 9 and the overlying unit. Northeast of Dutch Harbor, unit 10 reaches a maximum thickness of approximately 50 feet; elsewhere the unit is 10 to 20 feet thick. It grades laterally and vertically into thin-bedded sandstone and 
siltstone or into sandstone. Interbedded sandstone and siltstone at the base grade upward into the characteristic cobble mudstone. Locally the mudstone appears to have channeled the underlying sandstone and siltstone beds, and at several places northeast of Dutch Harbor the lower part is intertongued with unit 9 or directly overlies unit 8 . The upper contact is sharply defined in the type area. Unit 10 has yielded the only significant molluscan fauna from the entire Eocene sequence exposed on San Nicolas Island (loc. E-2). Turritella lawsoni and Turritella uvasana etheringtoni are the most common forms; both presumably are restricted to strata of middle and late Eocene age in California.

Large-scale slump structures are common in unit 10 and suggest that deformation within the unit was nearly contemporaneous with sedimentation, as the overlying and underlying units are not tightly folded. Locally derived clastic fragments of sandstone and siltstone within the mudstone and sandstone support this interpretation. The primary structures and sedimentary features suggest an origin of the contorted strata by submarine shumping possibly associated with turbidity currents as described by Crowell (1957, p. 1003-1005). The metamorphic pebbles and cobbles contained in unit 10 may have been reworked from older conglomerates such as those in unit 4 or from older conglomeratic strata not exposed on the island.

UNIT 11

Unit 11 is well developed half a mile north of Dutch Harbor, in the fault block across which stratigraphic section 6 was measured. This unit is much like unit 7 lithologically. In general, unit 11 is thick-bedded, poorly sorted micaceous arkosic sandstone that is predominantly medium to coarse grained. Elongate resistant calcareous concretions occur in some beds. The unit varies markedly in thickness and attains a maximum thickness of approximately 70 feet northeast of Dutch Harbor, but it may be only 10 feet thick in some fault blocks (pl. 5, stratigraphic section 4). The upper contact is conformable with the overlying unit.

UNIT 12

Unit 12 is a sequence of thin-bedded sandstone and siltstone that is best exposed north of Dutch Harbor in the fault block across which stratigraphic section 6 was measured. Fresh exposures of the fine- to mediumgrained arkosic sandstone, which generally occurs in beds less than 1 foot thick, are light gray but weather to yellowish gray. The siltstone is blue gray, weathers to olive gray, and much of it is clayey or sandy. Alternating beds of sandstone and siltstone 2 to 8 inches thick occur in approximately equal amounts in the lower part of the unit, but siltstone is predominant near the top. Bedding in unit 12 is relatively well defined by the thin resistant sandstone beds, but the unit as a whole forms slopes between the enclosing cliff-forming sandstone units 11 and 13 . Unit 12 ranges in thickness from 50 feet to approximately 100 feet. The upper contact with unit 13 is sharply defined but irregular, indicating a local minor unconformity.

UNIT 13

Unit 13 is a thick-bedded cliff-forming sandstone sequence closely resembling the lower part of unit 7 in lithology and bedding. Typical exposures of unit 13 are in the fault block across which stratigraphic section 6 was measured. Angular, very coarse grained arkosic sandstone and granule sandstone form very thin lenticular bodies within several of the sandstone beds, and nonpersistent siltstone and fine grained sandstone beds a few inches thick are present at irregularly spaced intervals throughout the unit. The angular granules are composed primarily of quartz and dense greenish-gray metamorphic-rock fragments. Cross-lamination and large tabular calcareous concretions occur in a few of the sandstone beds. Unit 13 maintains a relatively uniform thickness of 45 to 65 feet where measured. The lower part of the unit locally contains small tabular fragments and pellets of mudstone. The upper contact is relatively sharply defined.

UNIT 14

Unit 14 is a thin-bedded siltstone and sandstone unit similar in lithology to unit 12 . It is best exposed in the fault block across which stratigraphic section 6 was measured northeast of Dutch Harbor. Interbedded sandstone and siltstone in the lower part of unit 14 grade upward into siltstone that contains a few thin lenticular sandstone beds near the top. The amount of siltstone in proportion to sandstone varies from place to place, as does the thickness of the individual beds. Tabular fragments of siltstone several inches in length appear sporadically in some of the sandstone beds. The thickness of unit 14 is variable; in stratigraphic section 2 it is 28 feet thick and in stratigraphic section 6 it is 63 feet thick (pl. 5). The upper contact of unit 14 is gradational. Foraminfera are common in the siltstone beds throughout the unit.

UNIT 15

Unit 15 is a thick-bedded concretionary sandstone sequence resembling unit 7 in lithology and thickness. Typical exposures are in the large unfaulted area between structure sections $D-D^{\prime}$ and $E-E^{\prime}$ (pl. 3). The sandstone is arkosic and commonly medium grained but ranges from fine to very coarse. A 5- to 
15-foot siltstone bed containing thin layers of finegrained sandstone usually is present in the middle part of the unit. Thin lenticular siltstone and finegrained sandstone beds a few inches thick occur between the medium- to coarse-grained sandstone beds. Slump bedding and cross-lamination are commonly associated with normal bedding in the sandstone. The unit ranges in thickness from about 100 to approximately 140 feet and forms cliffs. Locally the top of unit 15 grades upward into interbedded sandstone and siltstone of unit 16 , but at most places the contact is fairly well defined.

$$
\text { UNIT } 16
$$

Unit 16 is the second thickest siltstone unit in the Eocene sequence exposed on San Nicolas Island, and in gross lithology it is similar to unit 6 . The best exposures are about 1 mile northeast of Dutch Harbor, adjacent to stratigraphic section 7 . The predominant rock type is blue-gray sandy siltstone interbedded with a few thin beds of calcareous fine-grained sandstone. Unit 16 differs from unit 6 in that several thin-bedded lenticular bodies of intercalated sandstone and siltstone occur locally within the unit. These sandy lenses, shown on plates 3 and 5 as units 16a, 16b, and $16 \mathrm{c}$, are not as thick bedded as those in unit $6 \mathrm{a}$ and contain proportionally more interbedded siltstone. The sandstone lenses form relatively resistant outcrops in the slope-forming siltstone and vary in thickness, distribution, and stratigraphic position. Unit 16 is 247 feet thick near Dutch Harbor and seems to be about 300 feet thick in the faulted area east of Celery Creek on the north side of the island. The upper contact of unit 16 is gradational. Foraminifera are common in the siltstone strata.

$$
\text { UNIT } 17
$$

Unit 17 is a sandstone sequence that is best exposed at the top of the cliff-forming outcrops along structure section $E-E^{\prime}$ (pl. :3). Most of the sandstone in the unit is medium grained but ranges from fine to very coarse grained. A few lenticular pebbly sandstone beds as much as 2 feet thick occur near the middle of unit 17. Angular granules and small pebbles of quartz are common in these lenticular beds, which contain lesser amounts of greenish-gray, gray, and yellowish-brown metamorphic-rock fragments. Occasional oyster-shell fragments occur with the rock fragments. Concentrations of mudstone balls and tabular fragments of siltstone in the unit indicate almost contemporaneous erosion and deposition and local minor unconformities. The sandstone is thin to thick bedded, relatively well bedded, and forms prominent cavernous-weathering outcrops. Thin siltstone and fine-grained sandstone beds a few inches thick separate many of the thick sandstone beds. Unit 17 is 114 feet thick in stratigraphic section 8 (pl. 5) and appears to vary only slightly in thickness. The upper contact is gradational.

The angularity of the granules in the coarser clastic sediments of unit 17 suggests a nearby source for the metamorphic-rock fragments during the deposition of the unit.

UNIT 18

Blue-gray siltstone unit 18 is similar in appearance to units 6 and 16, but it is not as thick as either. Unit 18 is well exposed just south of hill 606 , near the southeast end of the island. Approximately 50 feet of siltstone and thin-bedded calcareous sandstone is present slightly above the base of the unit. Siltstone is predominant in this basal interbedded interval, and a few thin beds of lime-cemented fine-grained sandstone occur in the middle part of the siltstone unit. Unit 18 is 163 feet thick in stratigraphic section 9 (pl. 5). The upper contact of the unit is conformable and usually sharply defined.

UNIT 19

Unit 19 is the thickest sandstone section in the sedimentary sequence of Eocene age exposed on San Nicolas Island. Cliff-forming outcrops that closely resemble unit 7 in lithology occur over most of the southeast end of the island. Unit 19 is primarily thick-bedded sandstone that locally contains relatively thin-bedded sandstone slightly above the base and near the middle of the unit. Generally the sandstone is highly arkosic, micaceous, and fine to medium grained. Thin beds of siltstone and fine-grained sandstone are present throughout the unit and tend to be thicker than other sandstone units. Slump bedding and current bedding are common in parts of the unit, and many small tabular fragments of siltstone are present in some of the thin sandstone beds. Unit 19 is 520 feet thick in stratigraphic section 10 (pl. 5). The upper contact is gradational.

UNIT 20 TO 30

The sequence of units 20 to 30 was mapped at the southeast end of the island and is discussed under a single heading because of its small outcrop area, similarity of rock types, and the lack of evidence for the determination of lateral variation in thickness and lithology. All these units are exposed in a small downfaulted block near Jehemy Beach. Stratigraphic sections 11 and 12 on plate 5 indicate the thickness and lithology of each unit. Units $21,23,25,27$, and 29 are relatively thin cliff-forming sandstone units much like unit 7 in lithology. Units 22, 24, 26, and 28 are thin interbedded sandstone and siltstone units that resemble unit 8 or the lower part of unit 12 . Units 


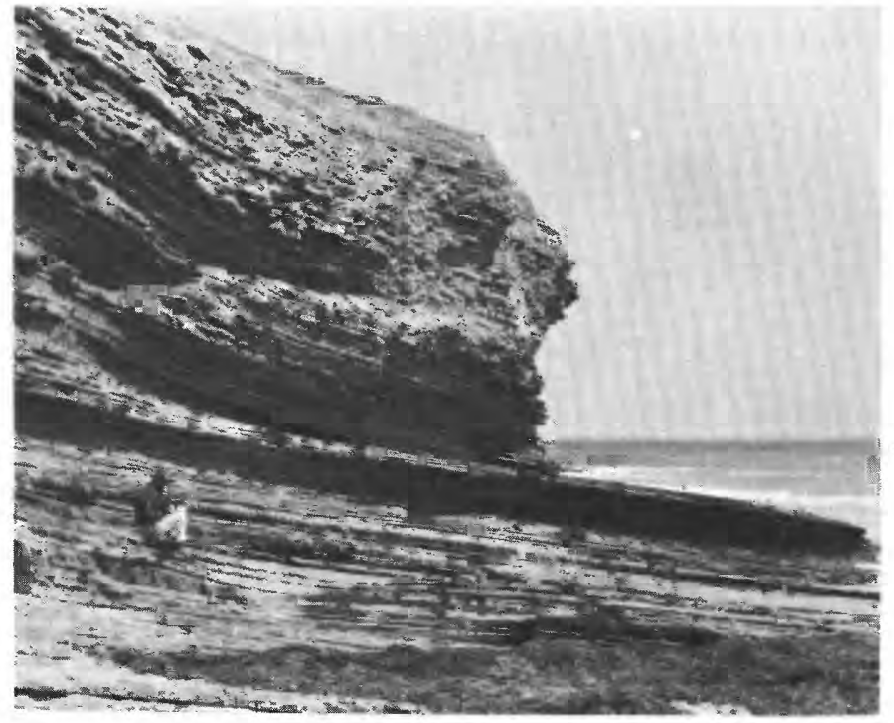

Figure 9.-Well-bedded siltstone and fine-grained sandstone in the lower part of unit 20 exposed in a sea cliff at the east end of the island. Siltstone beds predominate in unit 20 both above and below the pictured sequence of beds.

20 and 30 are siltstone units that have the same general appearance and lithology as unit 6 (fig. 9). The top of unit 30 is not exposed owing to faulting. The combined thickness of units 20 through 30 is approximately 450 feet; unit 20, the thickest individual unit, is 108 feet thick. Foraminifera are present throughout the siltstone units and in the interbedded sandstone and siltstone units.

\section{ZONE A}

Two fault blocks in the sea cliff west of Jehemy Beach contain beds of siltstone and interbedded sandstone and siltstone that have not been differentiated stratigraphically because they are poorly exposed. This faulted outcrop is designated zone $\mathbf{A}$ on plate 3 and probably represents parts of units 26,27 , and 28 .

\section{ZONE B}

Outcrops of siltstone beds of uncertain stratigraphic position that are isolated by Quaternary deposits or faults of unknown displacement are assigned to zone B on plate 3. All siltstone outcrops designated as zone $\mathrm{B}$ occur in the stratigraphic sequence somewhere between units 5 and 17.

ZONE C

Included in zone C are isolated outcrops of thickbedded sandstone of unknown stratigraphic position, or sandstone units that occur in an undifferentiated sequence of beds. All sandstone beds designated zone C on plate 3 occupy a stratigraphic position somewhere between units 6 and 18 .
ZONE D

Intercalated thin-bedded sandstone and siltstone beds that individually cannot be assigned to numbered units either because they are isolated from known units or occur in an unknown sequence of units are placed in zone $\mathrm{D}$. All units assigned to zone $\mathrm{D}$ lie at unknown stratigraphic positions between units 7 and 18 .

ZONE E

Due to the intense weathering of the rocks, dunesand cover, or the indefinite nature of the contacts, a sequence of beds lying between units 8 and 12 has not been differentiated northwest of Seal Beach and west of Sand Dune Canyon. These beds are shown as zone E on plate 3.

IABORATORY ANALYSES OF EOCENE SANDSTONE SAMPLES

Laboratory study of 15 sandstone samples selected at random from the sedimentary section of middle to late Eocene age on San Nicolas Island was undertaken to determine the physical character of the sandstone beds and to ascertain whether the mineralogic compositions suggest possible source areas for the sediments.

The sandstone samples were collected at irregular intervals, the lowest near the top of unit 3 and the highest at the top of unit 19. Thus, the samples span about 2,500 feet of the exposed section. In addition to thin-section studies of the samples, mechanical-analysis, heavy-mineral, and porosity and permeability determinations were made. The results of the laboratory analyses are listed in table 2 and in figure 10.

Thin-section studies indicate that quartz is the most abundant mineral and constitutes 40 to 60 percent of the grains in nearly all the thin sections. Most of the quartz grains are clear, angular, generally without inclusions, and exhibit sharp extinction. The sandstone samples from San Nicolas Island average 48 percent feldspar, most of which is oligoclase with lesser amounts of andesine, orthoclase, and microcline. Determinations of 5 to 10 grains of plagioclase selected at random in each thin section show that oligoclase is the predominant plagioclase and that andesine and other varieties are relatively rare. Potassium feldspar is present in all the samples, and about one-third or less of the potassium feldspar is microcline. A few grains of perthite are present in about half the slides. The most abundant accessory mineral in the sandstone samples is biotite. Muscovite is less common than biotite, and hornblende is rare. Fine-grained dark-colored rock fragments, chiefly of metavolcanic origin, comprise 8 to 20 percent of the total grains. The majority of the slides also contain discrete calcite grains that may be detrital rather than secondary grains. 


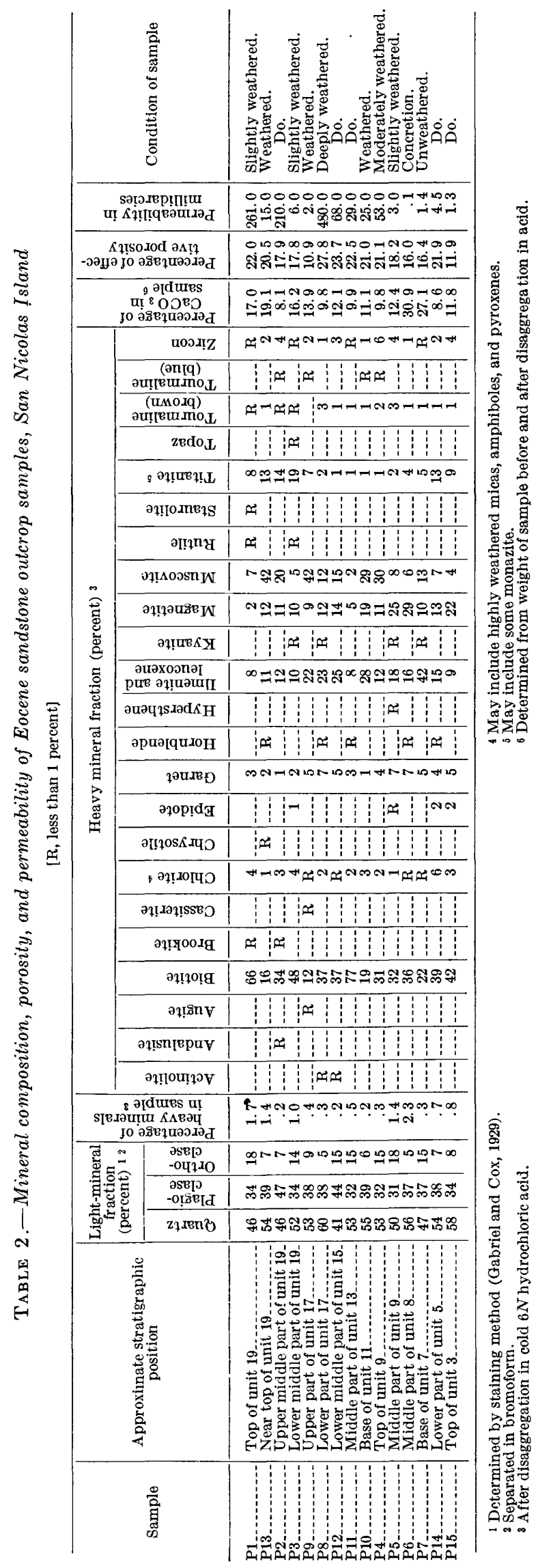



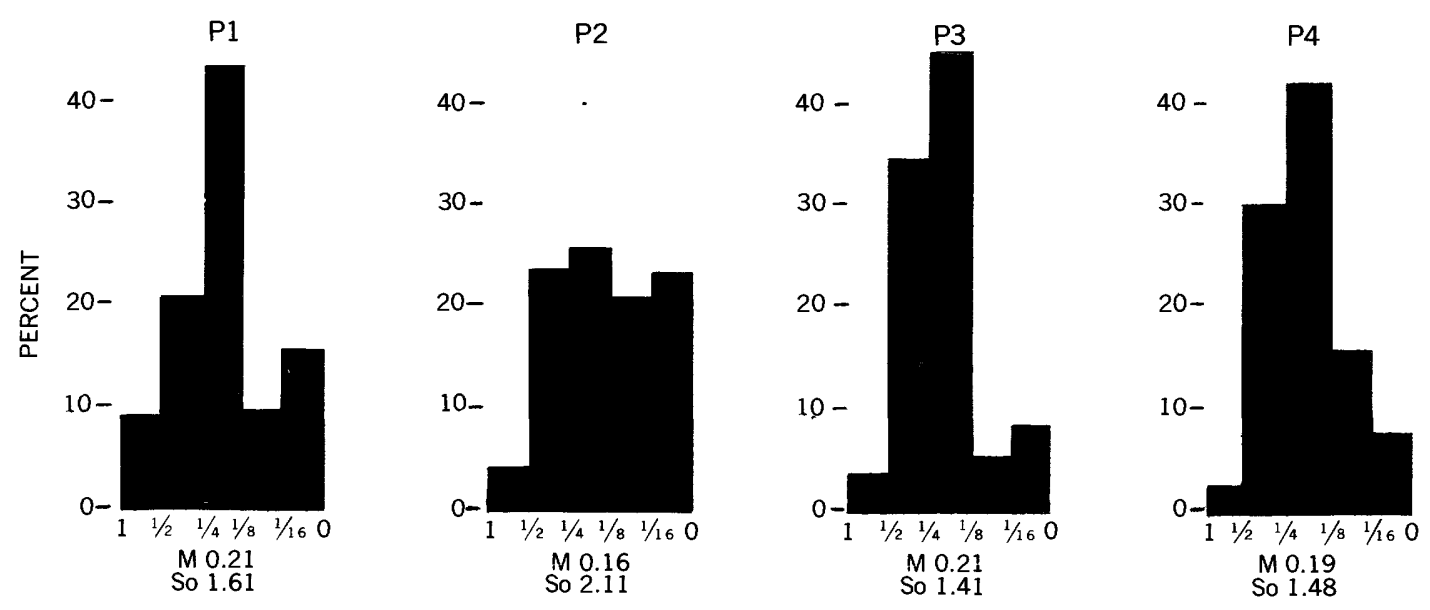

P5
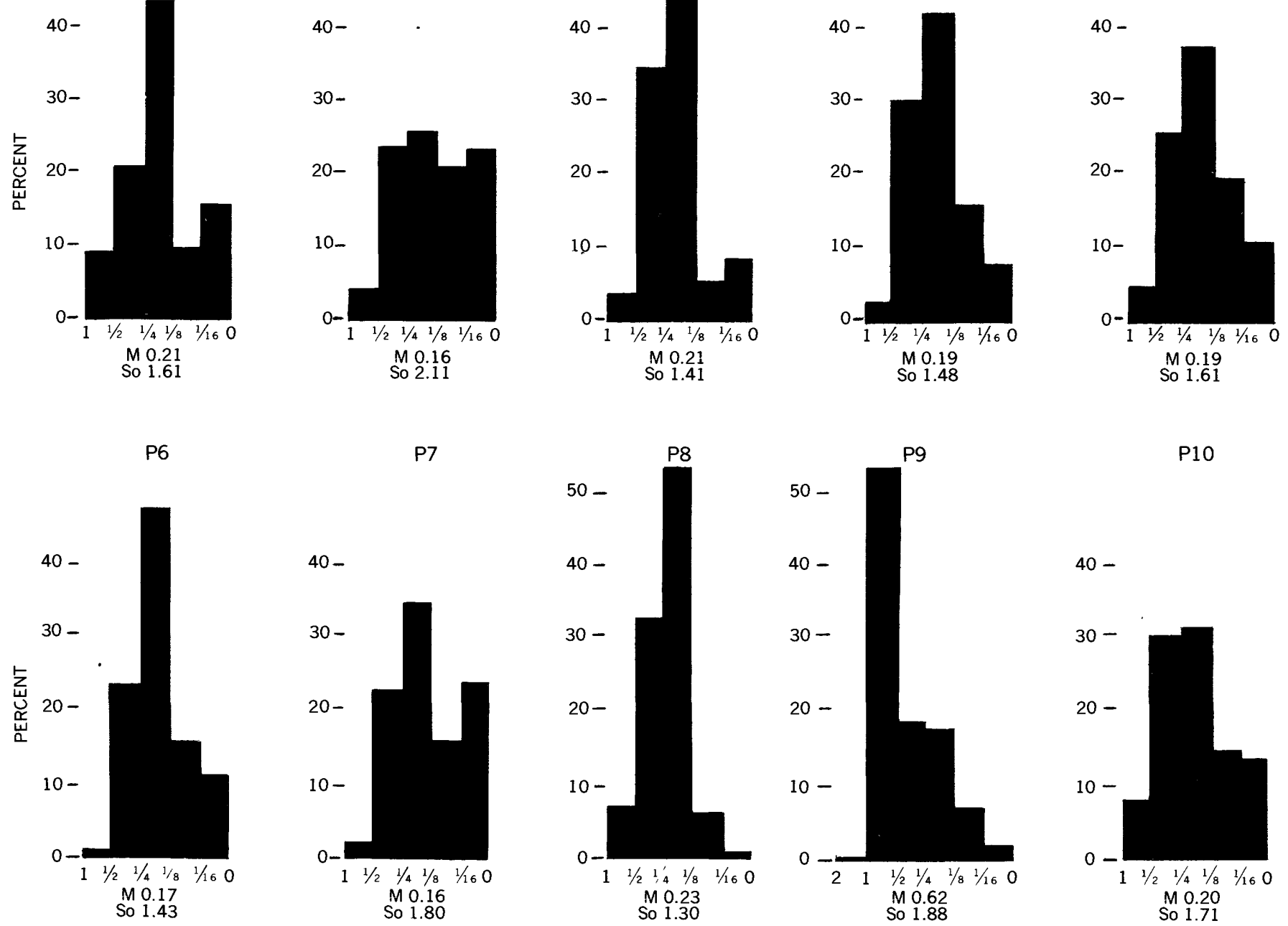

P11
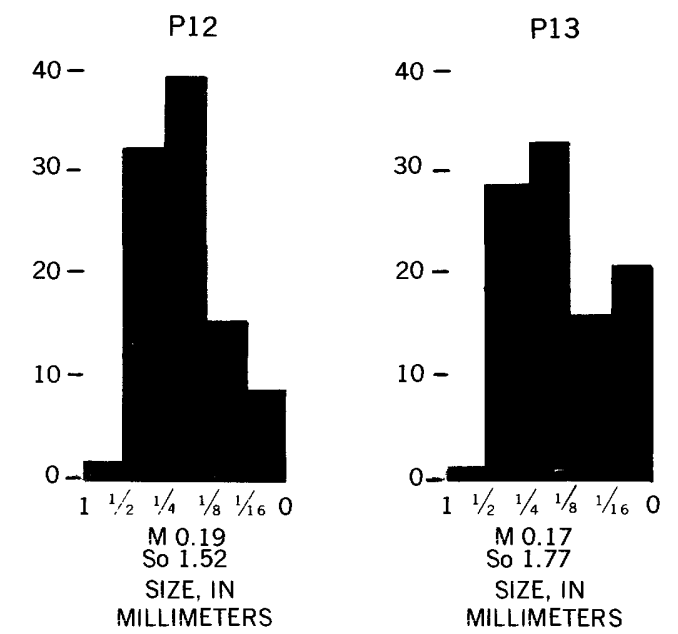

P14

P15
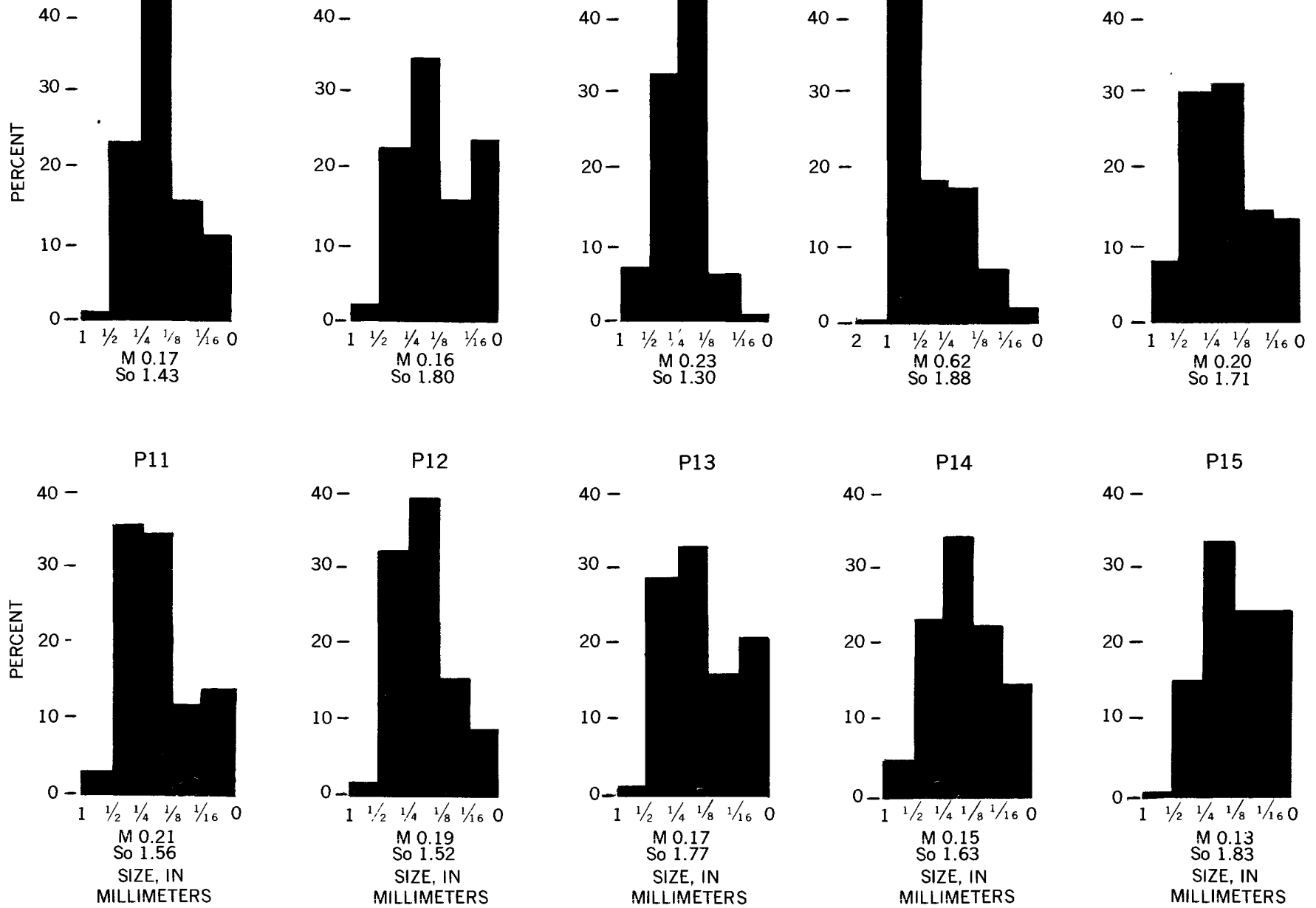

FigURE 10.-Histograms showing grain size in the samples of Eocene sandstone. Median diameter in all the samples is within the limits of fine sand (Wentworth, 1922) with the exception of sample P9. Explanation of symbol: M, median diameter; So, sorting coefficient (Trask, 1932). 
Calcite is the common cementing agent in the sandstone, but it may be a secondary replacement of a clay matrix. Some ferruginous clayey material that may also act as a cementing agent was observed in several thin sections.

The mineralogic character of the sandstones from San Nicolas Island resembles that of other Eocene sandstones from the California Coast Ranges. Reed (1928) reports that the average feldspar content is nearly 50 percent for Mesozoic and Tertiary sandstones in the Coast Ranges. Woodford (1925, p. 174-177) studied six samples of "Tejon" Eocene sandstones from the southeastern part of the Los Angeles basin and found that their feldspar content ranged from 12 to 60 percent. These "Tejon" sandstones, however, are not as consistently rich in oligoclase as are those from San Nicolas Island. An Eocene sandstone sample from San Diego analyzed by G. A. Macdonald for L. G. Hertlein and U. S. Grant, IV, (1944a, p. 44) has a composition similar to the "Tejon" samples except that it lacks biotite.

\section{SOURCE ROCKS OF THE EOCENE SANDSTONES}

The composition of the samples from the sandstone beds of Eocene age on San Nicolas Island suggests a source area of plutonic rocks of intermediate composition with lesser contributions from metamorphic rocks adjacent to igneous bodies. The nearest known occurrence of basement rocks of this type is on Santa Cruz Island, where hornblende diorite and quartz diorite intrude schists, phyllites, and greenstones of preCretaceous age (Bremner, 1932, p. 13-16). However, similar basement-rock types, possibly now buried by middle and late Tertiary sedimentary rocks on the sea floor, may have provided a source for the Eocene sedimentary rocks on San Nicolas Island. Many of the rock fragments in the sandstone samples resemble the metamorphic rocks that occur in the Eocene conglomerate beds on the island. No source area is known for rocks of this type although similar clastic fragments are common in conglomerates of Cretaceous and Paleocene age exposed on San Miguel Island.

The metamorphic and plutonic rocks on Santa Catalina Island presumably were not the source rocks for the San Nicolas Island Eocene sandstone. Not one of the glaucophane schist minerals of the Catalina metamorphic facies of the Franciscan series (Woodford, 1924) has been found in the sandstones of San Nicolas Island. The intrusive quartz diorite porphyry on Santa Catalina Island has a fine-grained groundmass (Woodford, oral communication, 1957). Fine-grained rock fragments of this type were not seen in the sandstone samples from San Nicolas Island.
The distribution of quartz, sodium-calcium feldspar, and potassium feldspar suggests that the sandstones were derived chiefly from an igneous rock of intermediate composition, possibly a granodiorite or quartz diorite. The percentage distribution of the three essential minerals, with allowance for some decrease in the relative abundance of quartz during transport, shows a fairly good correlation with a typical granodiorite or quartz diorite, although the anorthite content of the plagioclase is somewhat low. Nearly all the mineral grains are angular, and most of the quartz grains have sharp extinction. The marked angularity of zircon, garnet, and titanite grains further suggests that the sandstones were derived from igneous and metamorphic source rocks rather than having been reworked from sedimentary rocks (Pettijohn, 1957, p. 512-514).

\section{CORRELATION}

Marine strata of Eocene age are widely distributed over much of southern California, but many local areas of outcrop have been inadequately studied. The best known stratigraphic sections of marine Eocene sedimentary rocks in southern California occur at the south end of the San Joaquin Valley, in the Santa Ynez Mountains, and near La Jolla. For comparison with the exposed section on San Nicolas Island, the formations at the above-named localities are breiefly described.

The correlation chart (fig. 11) indicates the relative ages of well-known formations of Eocene age in central and southern California. Included on the chart are the little-known rocks of the same age on Santa Cruz and San Nicolas Islands.

The type area of the Tejon formation lies at the south end of the San Joaquin Valley, about 35 miles south of Bakersfield. The formation consists of approximately 3,500 feet of sedimentary rocks and has been subdivided into four members (Marks, 1943, p. 534-538; Beck, 1952). In ascending order, these are the Uvas sandstone and conglomerate member (110 feet thick), the Liveoak member composed predominantly of interbedded sandstone and siltstone $(1,970$ feet thick), the Metralla sandstone member (1,300 feet thick), and the Reed Canyon siltstone member (160 feet thick). Much of the section is highly fossiliferous and is considered to range in age from late middle to late Eocene.

An exceptionally thick section of Eocene sedimentary rocks is present in the Santa Ynez Mountains, which trend parallel to the coast in the vicinity of Santa Barbara. About 8,000 feet of marine strata assigned to the upper Eocene was penetrated by the Tecolote Tunnel 12 miles northwest of Santa Barbara. 


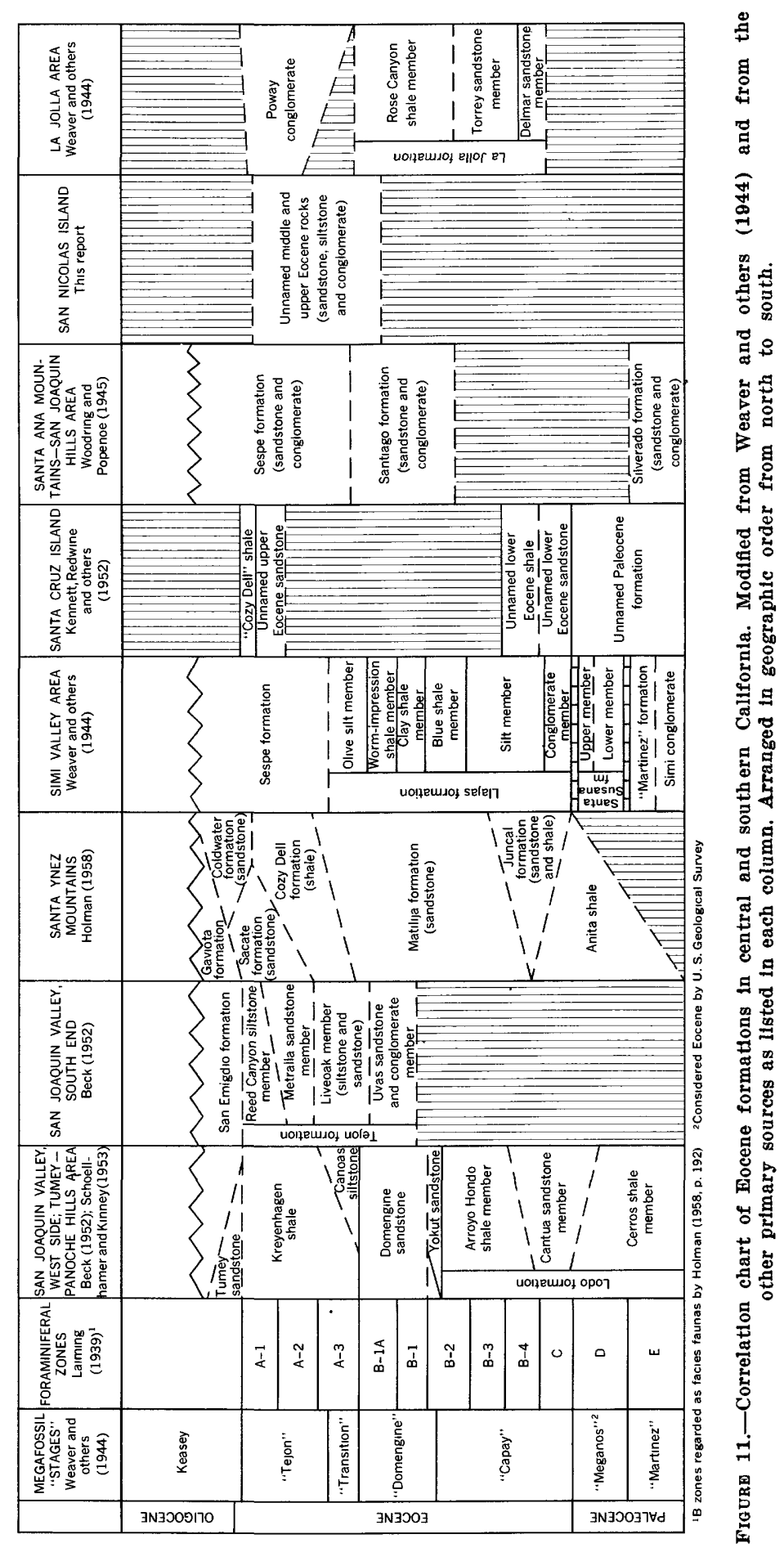


There the section is composed of the Matilija formation, which is predominantly sandstone $(1,400 \pm$ feet thick), and the overlying Cozy Dell formation, which is predominantly siltstone $(6,600 \pm$ feet thick) (Trefzger and others, in Redwine and others, 1952; Holman, 1958 , p. 192). About 15 miles west of the tunnel, the Matilija formation thins to 1,100 feet and is underlain by $600 \pm$ feet of the Anita shale; the Cozy Dell formation thins to $900 \pm$ feet and is overlain by about 1,300 feet of sandstone of the Sacate formation (Dibblee, in Redwine and others, 1952; Holman, 1958, p. 192). Megafossils are rare throughout the stratigraphic sequence, but Foraminifera are common in the siltstone and shale beds.

On the north side of Simi Valley, which lies nearly halfway between Ventura and Los Angeles, a highly fossiliferous section of lower and middle Eocene marine sedimentary rocks is exposed. About 2,800 feet of siltstone, sandstone, and shale assigned to the Santa Susana formation of early Eocene age is overlain by approximately 1,800 feet of interbedded siltstone, shale, and sandstone and a basal conglomerate. This sequence of beds is known as the Llajas formation and has been subdivided into six members, all of which are presumably middle Eocene in age (Stipp, 1943, p. $419,422)$.

Thirty-five miles southeast of Los Angeles on the southwest flank of the Santa Ana Mountains, marine strata of probable middle Eocene age are designated the Santiago formation (Woodring and Popenoe, 1945). Here a basal conglomerate overlain by marine fossiliferous sandstone that grades upward into nonmarine(?) conglomeratic sandstone attains a maximum thickness of nearly 2,700 feet.

In the vicinity of La Jolla, sedimentary strata of Eocene age are about 1,600 feet thick. Hanna (1926, p. 207-214) called the marine part of the section the La Jolla formation and subdivided it into the Delmar sand at the base (200 feet thick), the Torrey sand (25 to 200 feet thick), and the Rose Canyon shale (300 feet thick). The richly fossiliferous Rose Canyon shale member is assigned a middle Eocene age. Lenses of marine strata near the base of the overlying Poway conglomerate (875 feet thick?; Hanna, 1926, p. 213215) probably are late Eocene in age. The bulk of the Poway conglomerate is thought to be late Eocene on the basis of vertebrate remains (Stock, 1937, p. 53; Hertlein and Grant, 1944a, p. 42-43).

\section{IGNEOUS ROCKS}

Near the southeast end of San Nicolas Island several small igneous dikes of variable composition intrude

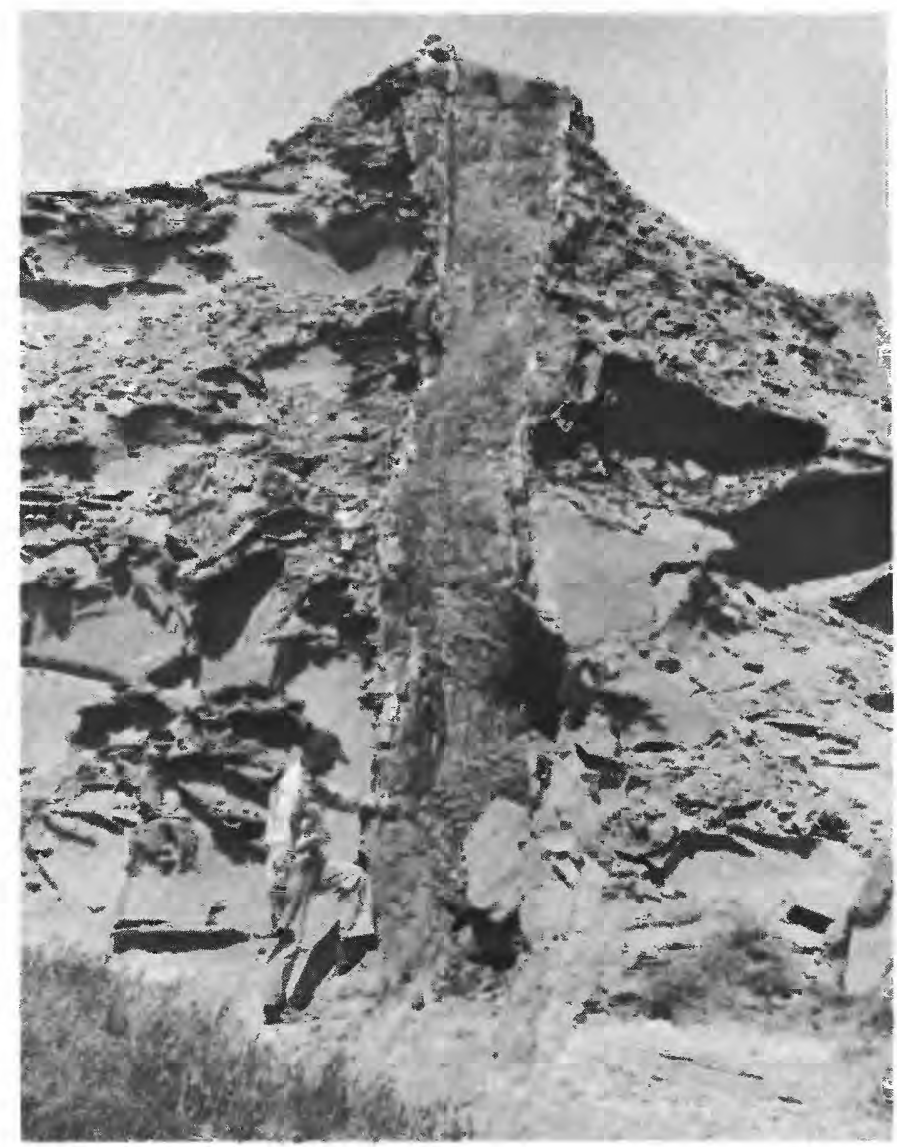

FIGURE 12- Narrow igneous dike cutting a sandstone bed in unit 14 about three-quarters of a mile east of Dutch Harbor. At this locality the dike is composed of porphyritic andesite showing trachytic texture.

the Eocene sedimentary rocks. The dikes attain a width of more than 6 feet in only a few places and generally are but 2 or 3 feet wide. Narrow resistant ridges usually border the outer margins of the dike rock, but there is little baking on the adjacent sedimentary rocks (fig. 12). The dike rock weathers to olive-gray outcrops that ordinarily are less resistant to erosion than the bordering sedimentary rocks.

Thin-section studies of three samples of dike rock (samples V1, V2, V3, see pl. 3) indicate that the rock is slightly vesicular dark-gray diabase with basaltic composition. The plagioclase in these sections was determined as $\mathrm{An}_{45}$ to $\mathrm{An}_{50}$; the pyroxene, as augite. Secondary calcite is also present, and possibly altered olivine. All three samples of diabase have holocrystalline ophitic texture with an average phenocryst size of about 1 millimeter. A fourth sample (V4) from the northernmost dike near the coast is porphyritic andesite with trachytic texture in which phenocrysts of plagioclase 3 millimeters in length are common. 


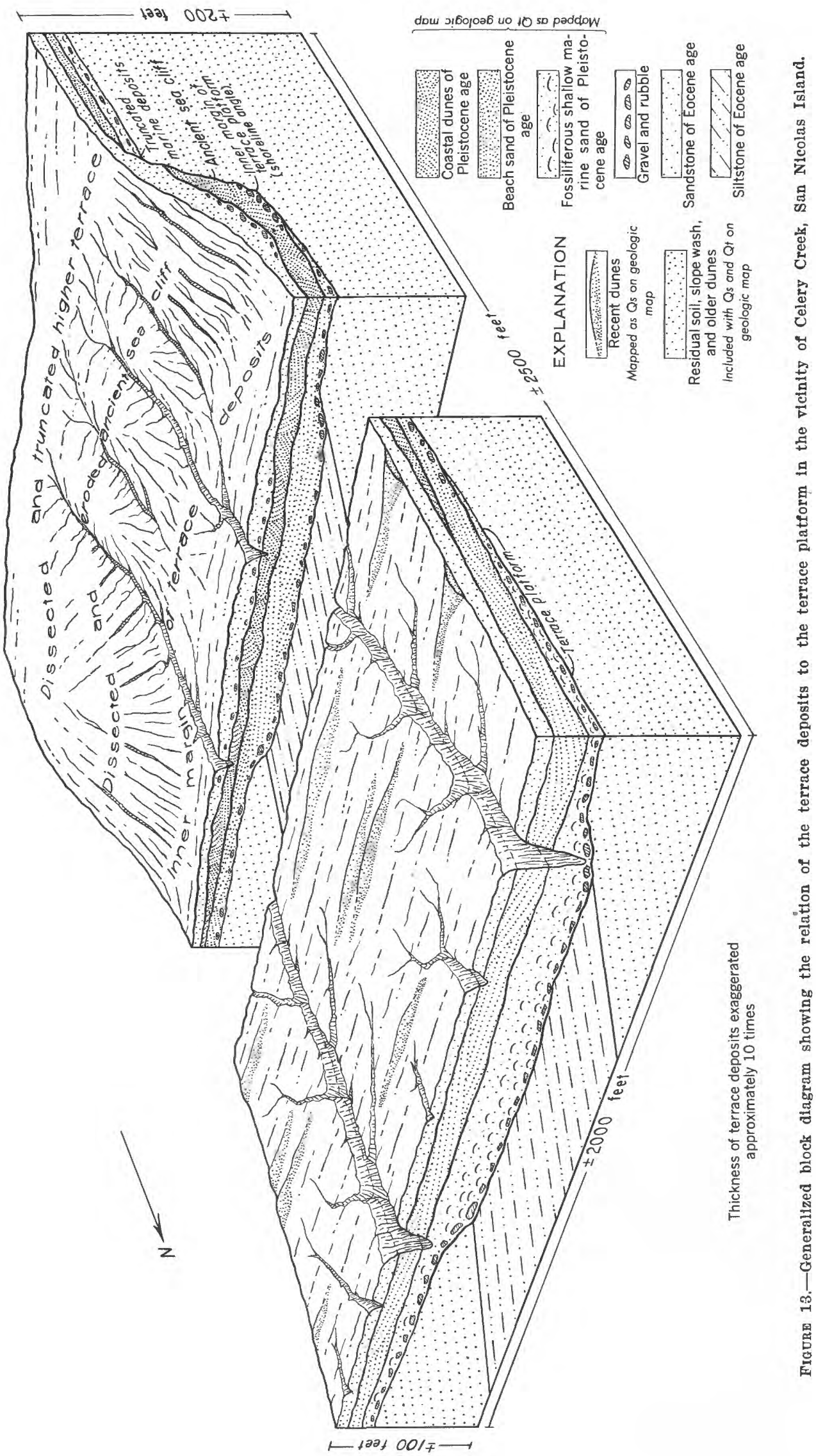


The composition of the plagioclase in sample $\mathrm{V} 4$ is $\mathrm{An}_{40} \pm$. Altered pyroxene(?) and secondary calcite are present in the same sample.

Apparently most of the intrusive rocks were emplaced along joints rather than faults or were independent of the joint systems, as observable displacement of the bedding in the adjacent sedimentary rocks was found only at one locality. Some of the dikes become narrow and terminate before reaching fault traces and appear again on the opposite side of the faults, suggesting that the fault planes served as barriers to the intrusive rocks. Other dikes bend, but do not cross fault traces and are confined to a single fault block. The southernmost of the two small discontinuous dikes, which is 2,400 feet south of hill 606 , can be traced westward to its termination in a narrow joint less than an inch wide.

The age of the intrusive rocks is unknown, other than that they presumably were intruded after the main faulting episode and that they are older than the terrace gravels. It seems reasonable to relate them to the intrusive and extrusive rocks of middle Miocene age that constitute most of the rock exposures on Santa Barbara Island, San Clemente Island, and parts of the northern group of islands.

The relation of the rhyolite obtained at Begg Rock by Kemnitzer (p. 6) ${ }^{18}$ to the intrusive rocks on San Nicolas Island is not clear, but the offshore exposure may be a remnant of a flow similar to the rhyolite flows of middle Miocene age on Santa Cruz Island (Bremner, 1932, p. 22-24) and on San Clemente Island (Olmsted, 1958, p. 62). The composition of the intrusive rock sampled from an elongate shoal $33 / 4$ miles northeast of Army Camp Beach (Norris, p. 22-24) ${ }^{19}$ suggests an association with the dike rock exposed on San Nicolas Island.

\section{QUATERNARY SYSTEM}

More than half of San Nicolas Island is covered by deposits of Quaternary age that include dune sand, marine terrace deposits, beach sand, small amounts of alluvium, thin residual soils, and slope wash.

Deposits of Quaternary age attain maximum development in the low western part of the island where thick dune sand blankets the older rocks. Some stream channels that transect the low western area are more than 50 feet deep, yet fail to expose either the marine terrace deposits or the bedrock. Extensive marine terrace deposits, masked by a nonmarine cover, obscure the bedrock over much of the central and northeastern parts of the island.

\footnotetext{
${ }^{18}$ See footnote 1, p. 4.

is See footnote 2, p. 4 .
}

\section{PLEISTOCENE SERIES}

\section{TERRACE DEPOSITS}

The San Nicolas Island terrace platforms are covered with a variety of sediments of marine and nonmarine origin that range in thickness from a few inches to many feet. Generally the thickest accumulation of terrace deposits occurs at the inner edge of the platform and is composed of a mixture of unconsolidated, poorly stratified windblown sand and probable beach sand with scattered cobbles at the base. A cover of residual soil, slope wash, and talus included with the terrace deposits on the geologic map ( $\mathrm{pl} .3$ ) forms a thick deposit at the inner margin of the platform and thins progressively toward the outer edge. Vertical-sided stream channels, many of them more than 30 feet deep, commonly cut across these combined deposits at the inner edge of the platform without exposing bedrock (fig. 13).

Fossiliferous marine deposits have been observed on all the well-defined terrace platforms on the north and northeast sides of the island. The seaward edges of these marine deposits consist of poorly sorted calcareous sand and gravel composed primarily of mollusk shell fragments, echinoid plates and spines, calcareous algae, and bryozoans. Few of the fossiliferous parts of the terrace deposits are more than 5 feet thick. Pebbles and cobbles of metamorphic rock, $1 / 2$ inch to 6 inches in diameter, and tabular fragments of sedimentary bedrock, a few inches to several feet in diameter, commonly mark the base of the marine deposits (fig. 14). Toward the ancient sea cliffs the basal beds contain less calcareous material and more quartz

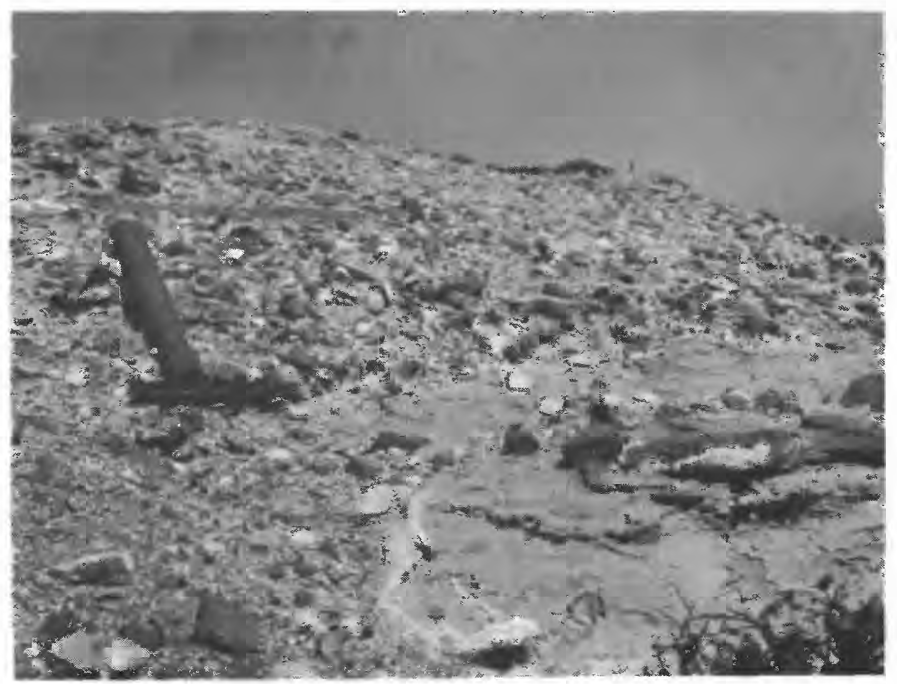

FigURE 14.-Well-preserved mollusks in a marine terrace deposit at an ultitude of 725 feet near fossil locality SN-2. The concretionary sandstone at the lower right is Eocene bedrock exposed near the surface of the terrace platform. 
and feldspar grains and sedimentary rock fragments, and the sand generally is finer grained. Close to the base of the ancient sea cliffs (shoreline angle) the beach sands grade laterally into, and are overlain by, old coastal dunes; some of the dunes display crossstratification and many attain a thickness of 20 feet or more. At places the calcareous material has been partly dissolved and redeposited by ground water to form cemented strata that locally are more resistant than the bedrock.

Small isolated patches and narrow bands of marine terrace material exposed along the eroded outer margins of terrace platforms are common over the western part of the island but are not shown on plate 3 because of their limited outcrop area.

Each marine terrace deposit is masked by nonmarine slope-wash debris derived from higher terrace levels and by dune sand of probable Recent age. In general, the slope-wash deposit is composed of gray to yellowbrown unconsolidated clayey and silty sand that locally is cemented by caliche. Scattered siltstone and sandstone fragments commonly occur near the inner margin of the deposit. The slope-wash cover is as much as 15 feet thick along the shoreward edges of some of the well-developed terrace platforms (fig. 15).

Scattered small subangular slabs of glaucophane schist occur in several of the higher terrace deposits and in the 100-foot terrace at Army Camp Beach. None of the conglomerate units in the bedrock sequence has yielded glaucophane schist, nor has glaucophane schist been observed in the adjacent offshore-shelf sediments collected either by the U.S. Geological Survey or by earlier workers. Glaucophane was not found in the heavy-mineral suites from the sandstone

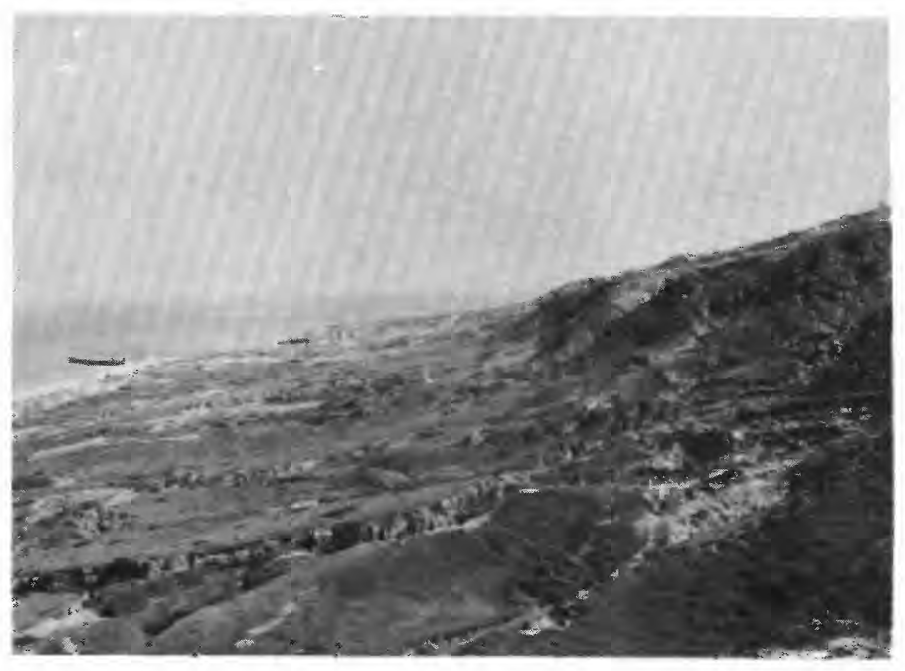

Figure 15, - A view southeast along the old sea cliff of the welldeveloped 100-foot terrace near Coast Guard Beach. Slope wash and Quaternary dunes conceal the terrace platform. samples studied from units throughout the Eocene sequence. It seems that during Pleistocene time a nearby source area supplied the glaucophane schist fragments found in the terrace deposits. The nearest known occurrence of basement rock containing glaucophane is on Santa Catalina Island, about 55 miles east of San Nicolas Island (Woodford, 1924, p. 49-68). Sedimentary rocks resembling the glaucophane schistbearing San Onofre breccia of middle Miocene age occur on Santa Cruz Island (Bremner, 1932, p. 21) and on Anacapa Islands (Scholl, 1959). No outcrops of rocks containing glaucophane have been reported from the sea floor in the intervening areas, although many local lenticular bodies of glaucophane schist breccia may occur in nearby submarine exposures of middle Miocene sedimentary rocks from which kelprafted schist fragments may have been transported to San Nicolas Island in Pleistocene time.

At several offshore stations, pebbles and cobbles too large to be moved by normal current action and pebbles encrusted with bryozoans and calcareous algae partly fill the troughs of channellike depressions that may have been formed by previous subaerial erosion. Presumably these pebble gravels, which show no evidence of recent abrasion and transport, are remains of, or are lag gravels derived from, submerged terrace deposits. Sponge-enveloped and bryozoan-coated pebbles dredged by Norris from the sea floor near Begg Rock also may indicate submerged terrace deposits far out on the shelf area, although kelp rafting may account for the presence of some isolated pebbles. Similar pebbles and cobbles are reported by Uchupi (p. 57, 60-61) ${ }^{20}$ from the surface of Santa Rosa-Cortes Ridge northwest of San Nicolas Island and Begg Rock.

\section{PLEISTOCFNE AND RECENT SFRIES,} UNDIFFERENTIATED

\section{WINDBLOWN SAND}

Many episodes of deposition of wind-transported materials can be recognized on San Nicolas Island, but all the eolian deposits are grouped into a single unit on plate 3 because of the difficulty in attempting to differentiate units within these deposits. These eolian deposits are classified into four categories for discussion: coastal dune deposits of Pleistocene age, older early Recent reddish-brown dune deposits, younger early Recent light-gray to yellowish-gray dune deposits, and active or recently active white to yellowish-gray dunes.

Coastal dune deposits of Pleistocene age are buried beneath terrace cover along the inner margins of many of the terrace platforms (fig. 13). Generally,

\footnotetext{
${ }^{20}$ See footnote 8 , p. 8 .
} 
these deposits are composed of light-gray to yellowishgray medium- to coarse-grained calcareous sandstone partly cemented by caliche. These sandstone beds are cross-stratified at a few places. Slope-wash debris, younger dune deposits, and residual soil ordinarily mask the older coastal dunes, and good exposures occur only along the walls of the deeper gullies that cut through to bedrock on the north and west sides of the island. About a mile west of BM 396, older coastal dune deposits were penetrated in drilling from 1 to 76 feet. However, these deposits are usually 10 to 20 feet thick.

The next youngest sequence of eolian deposits is most extensively distributed on the western part of the island where it is exposed in irregularly bounded areas covering as much as 50 acres. These deposits are composed of reddish-brown semiconsolidated medium-grained sand that fills depressions and channels in the bedrock topography and that overlies the coastal dune deposits of Pleistocene age. The fingershaped outcrops of these deposits are oriented parallel to the direction of the prevailing wind. As these longitudinal expanses of partly cemented reddishbrown sand are frequently littered with abraded shell fragments and scattered artifacts, and because winderoded shell mounds in all stages of destruction are common on these reddish-brown sand areas, it is evident that such areas have until recently been covered by active dunes that were used as refuse dumps by the aboriginal population. The thickness of the reddishbrown sand is extremely variable; a maximum of 35 feet is exposed in some steep-sided gullies, but deposits 2 to 10 feet thick are more common.

The windblown deposits overlying the reddish-brown sands consist of crossbedded light-gray to yellowishgray, poorly consolidated coarse-grained calcareous sands that extend along the edge of the prominent western escarpment, mostly between the 200- and 700foot contours. A few isolated patches of these windscoured deposits are present near hill 616, where they rest unconformably on the older reddish-brown dune sand. On some of the marine terrace deposits and over much of the western part of the island, these partly cemented eolian sands are in various stages of burial or erosion by windblown sand.

Youngest and most extensive of the eolian deposits are the active and recently active longitudinal dunes, composed of calcareous medium-grained sand, that blanket all the older sedimentary rocks over approximately one-third of San Nicolas Island. Northwesterly winds cause gradual movement of sand eastward along the lower terraces on the north coast and on the higher upland surface in the central part of the island.
In the western part of the island, shifting sand has obscured nearly all the terraces and has entirely filled some of the smaller canyons. The movement of sand along the steep southern escarpment is impeded by numerous deep canyons.

The thickness of the youngest windblown deposits is exceedingly variable, ranging from a few inches to more than 75 feet. On the western third of the island, below the 300-foot contour, auger borings and stream channels nearly 50 feet deep have not reached the base of the dune sand.

Most of the small isolated areas of active and recently active windblown sand that occur along the upper surfaces of the marine terrace benches in the central part of the island are not shown on plate 3 but are grouped with the terrace deposits (fig. 13). These small scattered dunes ordinarily are partly stabilized by vegetation where they occur on the welldeveloped marine terrace deposits.

The extensive tract of Pleistocene and Recent dune sand on the western part of the island presumably required a more extensive source of supply than is now available by wave action and longshore currents on the small existing beaches. Lower sea levels during part of Pleistocene time doubtless extended the shores of the island northwest, thereby materially increasing the length of the shoreline. It seems probable that these Pleistocene beaches, before submergence, provided much of the sand that was blown onto the present western upland surface of the island. Much of the sand was gradually anchored by vegetation, but periodic cycles of aridity presumably reactivated the dunes and overgrazing also may have resulted in the renewal of sand movement during the last century. Increased aridity also may have contributed to the loss plant cover and the reactiviation of the dunes.

The area covered by drifting sand spread appreciably between 1850 and 1940 according to the reports of visitors during that period (Cooper, in Whitney, 1865, p. 184; Schumacher, 1877, p. 46; Bowers, 1890, p. 60 ; Holder, 1910, p. 322). Field observations tend to confirm the recent disappearance of vegetation and the consequent increase in active dune areas. Many of the active dunes in the western part of the island, below an altitude of 300 feet, are strewn with myriads of shells of at least three species of land snails. Five forms of terrestrial snails are recorded by Hemphill (1901, p. 121-123, p. 137) ; presumably these were collected from dune deposits, as they are designated "subfossil." A few living representatives of one terrestrial species were found in the sparse vegetation on the eastern part of the island. The abundance of shells on the western dunes is regarded as indicating 


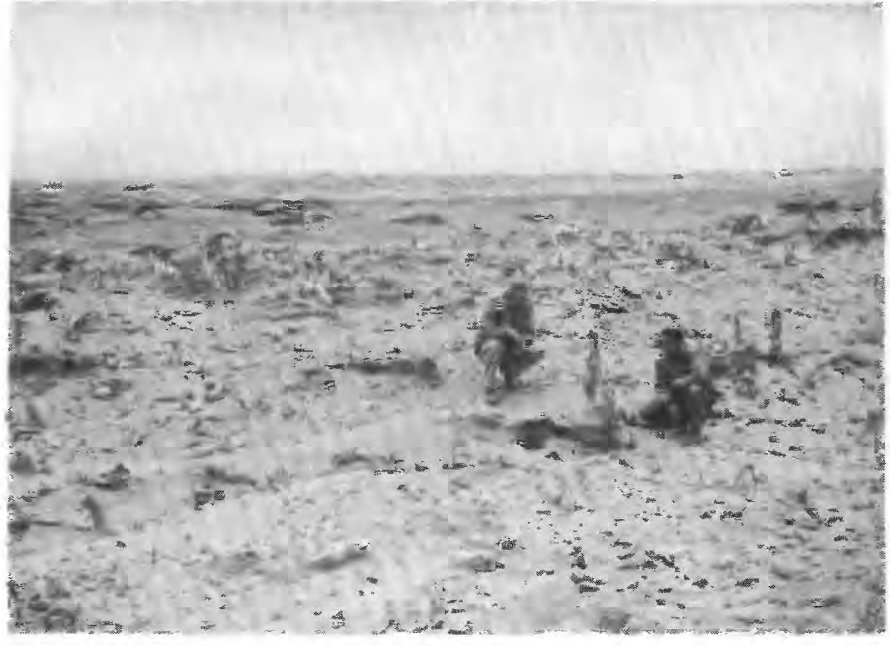

Figure 16. - Quaternary dune deposits and caliche at an altitude of about 825 feet on the western upland surface of the island. The dark areas are underlain by old dune sand over which thin drifts of active sand are moving. The projecting sumplike objects are calcareous root casts exhumed in wind-scoured trenches.

the former presence of a thick growth of vegetation. Parts of the western dune area are covered with numerous calcareous casts of the roots of shrubs and possibly small trees that range from a fraction of an inch to several inches in diameter (fig. 16). A similar occurrence of exhumed root casts on San Miguel Island is believed to be the result of overgrazing in historical time (Bremner, 1933 p. 9, 19). Comparison of aerial photographs of San Nicolas Island taken in 1943 with those taken in 1955 shows that the vegetation has made a gradual recovery since the sheep were removed.

\section{CALICHE DEPOSITS}

At many places on San Nicolas Island, particularly in the western part, removal of surficial deposits by deflation or stream erosion has exposed irregular areas of white sandy caliche, some several acres in extent Many of these deposits have a rough and jagged surface due to wind abrasion. They are nearly devoid of vegetation and present an appearance suggestive of a barren lunar landscape (fig. 16). Auger borings in both marine and nonmarine deposits of Quaternary age in all parts of the island indicate that caliche beds commonly occur from the surface to a depth of 40 feet.

Most of the caliche beds seem to be layers along which calcium carbonate was deposited by the downward percolation of rainwater containing calcium carbonate dissolved from overlying Quaternary deposits. A few caliche beds were derived directly from marine terrace deposits that have lost much of their original shell material owing to solution and redeposition of calcium carbonate. Other caliche beds seems to repre- sent concentrations of lime derived from the leaching of calcareous dune or beach sand that was deposited on impermeable clayey beds in the terrace deposits or on siltstone units in the Eocene bedrock.

The surfaces of many of the higher terrace and older dune deposits are strewn with yellowish-brown to reddish-brown ironstone concretions in varying abundance. These concretion-covered areas are best developed between Jackson Hill and hill 905. Most of the concretions are nearly spherical to ellipsoidal in shape and range from 6 to 20 millimeters in diameter. The less common larger concretions are irregular and have a maximum diameter of nearly 40 millimeters. All the concretions seem to have weathered out of old eolian deposits now partly destroyed by wind deflation. The degree of cementation of the concretions by iron oxide is variable, with poorly developed concentric banding commonly displayed on fresh surfaces. The sand in the concretions is composed predominantly of frosted subrounded to well-rounded medium-grained quartz and rock fragments and is embedded in a limonitic clay and silt matrix. Large flat irregular ironstone fragments composed of siltstone and mudstone are sporadically present with the ordinary spheroidal concretions.

Emery (1950, p. 220) believes that similar ironstone concretions which occur in the San Diego area were formed in place in weathered dune deposits by the concentration of iron-rich waters in highly permeable sands with equidirectional permeability. The larger tabular fragments of iron-cemented siltstone and mudstone may be remnants of argillaceous material deposited during local seasonal stands of muddy water which were later covered by active dunes and cemented by iron-bearing percolating water.

\section{RECENT SERIES}

\section{BEACH DEPOSITS AND ALLUVIUM}

Short sandy pocket beaches separated by headlands of thick-bedded sandstone are present along much of the coastline of San Nicolas Island. Shingle and boulder beaches occur locally along the west shore and in the extreme western part of the south coast. The southeast extremity of the island is an extensive sandspit that projects about a mile into the sea and is considered a beach deposit in this discussion.

Ninety samples collected from the sandy beaches around the island were studied by Norris (p. 20-23) ${ }^{21}$ and found to be predominantly well-sorted fine- to medium-grained sands with median diameters of 0.17 to $0.46 \mathrm{~mm}$. One sample collected near Vizcaino Point contains very coarse grained granule sand composed

\footnotetext{
${ }^{21}$ See footnote 2, p. 4 .
} 
of shell fragments with a median diameter of $2 \mathrm{~mm}$. Calcium carbonate constitutes 4 to 97 percent of 68 sands analyzed, with an average of 13 percent. The calcareous material in all the samples is made up chiefly of comminuted shell fragments.

The bulk of the calcareous material in the beach sands presumably was derived from pockets of shell debris deposited below the lower half of the intertidal zone, the zone that lies between extreme high and extreme low tide. Few shell-bearing mollusks or echinoids live above half-tide level at San Nicolas Island, and although some forms are exposed by low tides, by far the greater number of species live in slightly deeper water. The remainder of the beach sand was derived mainly from fluviatile detritus eroded from the island, wave erosion of sea cliffs and tidal benches, windtransported sand, and debris picked up along the shallow shelf by strong longshore drift and wave turbulence.

Deposits of alluvium occur in many of the large ravines on the south side of San Nicolas Island, but they are generally too small to be mapped. Only in Sand Dune Canyon and in the large canyon immediately to the west are the alluvial deposits of sufficient extent to be shown on plate 3. Commonly, the alluvium consists of silty sand, water-transported dune sand, and large talus blocks of sandstone moved down the ravines during heavy rains.

\section{OFFSHORE SHELF AND SLOPE DEPOSITS}

The shallow shelves around San Nicolas Island and other southern California islands are characterized by extensive areas covered with coarse-grained calcareous sediments. Frequently these sediments form a thin unconsolidated layer on the bedrock surface. The limy material around San Nicolas Island is composed of variable proportions of mollusk shell fragments, tests and spines of echinoids, barnacle plate fragments, bryozoans, and tests of foraminifera. Inorganic materials consist of a feldspathic quartz sand and numerous well-rounded metamorphic pebbles, probably derived mainly from the conglomerates of Eocene age.

Norris (p. 42-49) ${ }^{22}$ reports that the shell content of the bottom sands varies from less than 10 to more than 90 percent in short distances and that it is impractical to make any systematic differentiation of these materials on bottom-sediment distribution maps. Disregarding the percentage of calcareous material, bottom sampling showed that the most extensive sandy area occurs northeast of the island between depths of 120 and 200 feet. Other more restricted sand areas cover the sea floor near the sandspit, extend outward

\footnotetext{
${ }^{22}$ See footnote 2, p. 4.
}

from the sandy beaches to the 10-fathom depth contour, and fill isolated pockets and troughs on areas of rocky bottom. Rocky bottom is so prevalent around San Nicolas Island that it is extremely doubtful if any large unbroken area of the bottom is completely sand covered.

Very little Recent sediment was found by the divers on the shelf area west of San Nicolas Island. Current action and surge from the seasonal heavy south swell partly account for the small amount of Recent sediment in water less than 100 feet deep west of the island. Small pockets of deeply ripple-marked very coarse-grained sand or granule sand composed almost entirely of fragments of mollusks, echinoid plates and spines, and comminuted barnacle plates occur sporadically over the sea floor in this part of the shelf area.

Fifty samples of shelf sediments analyzed by Norris (p. 49) ${ }^{23}$ show that the carbonate content ranges from 11 to 100 percent. The sand samples average 49 percent carbonate, which is more than three times the average value obtained for the beach sands. The highest percentages occur in the shelly sands north and west of the island, many samples of which are more than 80 percent carbonate. The lowest percentages are present in the predominantly inorganic sands south of the island, where they average only 28 percent carbonate.

Median grain-size diameters of the bottom sand samples range from $0.09 \mathrm{~mm}$ in the finest sample to more than $4.0 \mathrm{~mm}$ in the coarsest sample. All the sand samples are well sorted. Sediments on the shelf areas do not exhibit any uniform size gradation from the shore to the edge of the shelf; sediments near the edge of the shelf are likely to be as coarse or coarser than sediments near the island coast. The slope sediments, however, are uniformly finer grained than the shelf sediments.

The steep slope beyond the 60 -fathom contour at the outer edge of the insular shelf is generally covered with a mixture of mud and sand. Dredging along this slope (Norris, p. 50-51) ${ }^{24}$ commonly yielded rocks in the muddy sand, but these generally show no signs of fresh abrasion by recent transport, and some display borings and the remains of attached organisms that may have been killed by submergence beyond their normal habitat in late Pleistocene time. The mud and sand are usually olive green and are rich in the tests of Foraminifera; they include 60 to 85 percent silt and sand, and the remainder is clay. Much of the sand is composed of broken shell fragments. Twelve samples of

${ }^{23}$ See footnote 2, p. 4

${ }^{24}$ See footnote 2, p. 4 . 
slope sediments analyzed contained an average of 29 percent carbonate.

\section{STRUCTURE}

The rocks of Eocene age exposed on San Nicolas Island are folded into a broad complexly faulted anticline that plunges southeast. Much of the structure is obscured by deposits of Quaternary age, but the fault pattern and the general trend of the main fold are evident along the well-exposed south side of the island. Intersecting high-angle normal faults produce pronounced offsets in the gently dipping beds along the axis of the anticline (pl. 3).

\section{FAULTS}

Two prominent sets of faults cut the Eocene sedimentary rocks; these faults intersect at nearly right angles, one set trending about N. $80^{\circ} \mathrm{E}$. and the other about N. $30^{\circ}$ W. A third minor set of faults trends about N. $20^{\circ} \mathrm{E}$. The two larger sets of faults intersect the fold axis at about $45^{\circ}$. Observations by geologic divers off the west end of the island indicate that the same complex fault pattern exists in the bedrock exposed on the sea floor.

Nearly all the faults exposed on the island are highangle normal faults that have displacements ranging from less than a foot to more than 750 feet (fig. 17). Although numerous faults with a throw of less than 15 feet were noted during the fieldwork, few of this magnitude are shown on plate 3. Apparently, the main

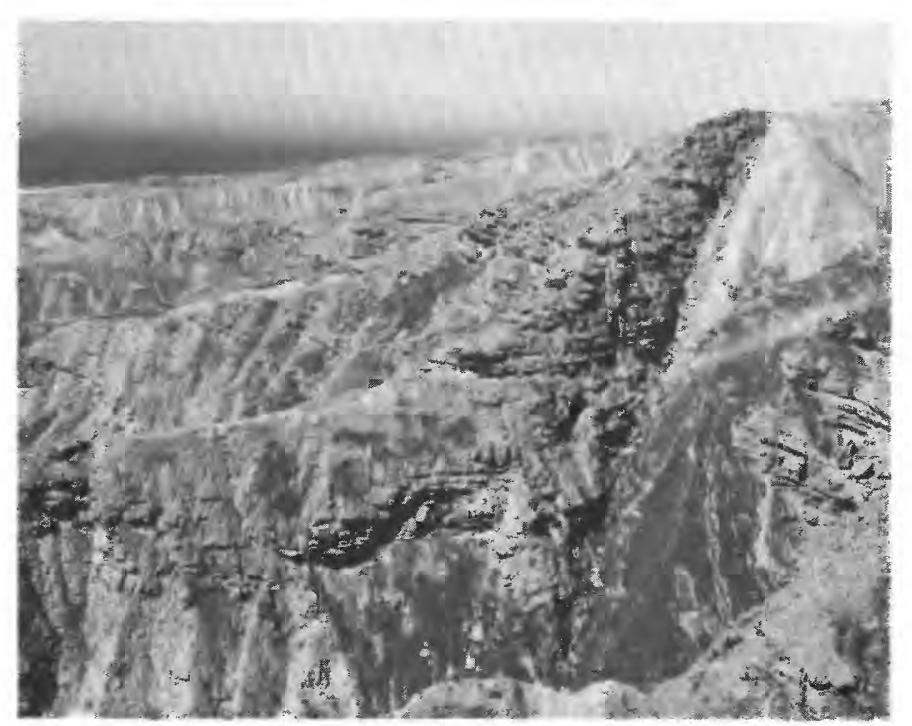

Figure 17.-A westward view of a normal fault exposed near the east end of the island. At this locality the throw on the fanlt is approximately 450 feet, down-dropping sandstone unit 19 on the left against siltstone unit 18 and sandstone unit 17 on the right The visible part of the canyon wall along the trace of the fault is about 275 feet high. fault systems developed almost simultaneously, for one set of faults alternately offsets the other. The maximum throw on the largest east-trending fault is approximately 650 feet (pl. 3, structure section $D-D^{\prime}$ ) but diminishes to the east. The largest north-trending fault has a throw of nearly 800 feet (pl. 3, structure section $F-F^{\prime}$ between the bend in section and the intersection of structure section $C-C^{\prime}$ ). Most of the dips measured on the fault surfaces range from $70^{\circ}$ to $80^{\circ}$. One large, relatively low-angle normal fault extends from Seal Beach east to a point about half a mile south of Jackson Hill. The inclination of the fault plane ranges from $41^{\circ}$ to $66^{\circ} \mathrm{N}$. Drag folds and brecciation are rarely associated with the faults on San Nicolas Island, and the zone of disturbed strata bordering the faults is usually confined to a few feet or less. No evidence was found for a strike-slip component of movement on the faults.

The exact age, or ages, of the faults on San Nicolas Island is unknown other than that they are postEocene; but as the sedimentary rocks at the southeast end of the island are cut by igneous dikes, most of which do not seem to have been displaced by faults, one faulting episode may have been preintrusion. However, not one of the larger fault planes shows evidence of intrusion, as might be expected if the main faults are older than the dikes. If the dikes are related to the middle Miocene volcanic rocks on the other Channel Islands, the age of the earliest faulting is presumably pre-middle Miocene and may have been contemporaneous with extensive faulting of early middle Miocene age on the mainland. Fifteen hundred feet east of the largest dune in Sand Dune Canyon, terrace deposits of presumed late Pleistocene age have been displaced a few feet along the projected trace of an older large fault, suggesting that continuing slight movements may have occurred since middle Miocene time. It is difficult to eliminate possible faulting episodes between the time of intrusion and the deposition of the terrace deposits on the evidence available from the island geology. The presence of successive untilted marine-terrace platforms of Pleistocene age to an altitude of 900 feet indicates partial regional uplift, in addition to eustatic changes in sea level; of the entire island platform during Quaternary time. It is questionable whether regional uplift contributed to the main fault system exposed on San Nicolas Island. Because the terrace deposits show no demonstrable evidence of tilting and are known to be faulted at only one locality, it is probable that the fault system was formed as a result of folding before the elevation of the island platform. 
Large offshore faults that may have effected the regional uplift of the San Nicolas Island platform are postulated by Shepard and Emery (1941, fig. 18, p. 47), Norris (p. 59-61), ${ }^{25}$ and Corey (1954, fig. 1, p. $74)$. The northernmost of the two inferred large offshore faults trends about $\mathrm{N} .44^{\circ} \mathrm{W}$. and parallels the southwest margin of the Santa Cruz Basin approximately 11 miles northeast of the east end of San Nicolas Island. A second large fault that trends about $\mathrm{N}$. $86^{\circ} \mathrm{E}$. is postulated about 4 miles south of the island along the northwest margin of the San Nicolas Basin. The steep angle $\left(11^{\circ}\right)$ of the slope of the sea floor on the southeast side of the island, recent earthquake epicenters located in this area, and the probable fault-line scarp indicated by the eroded south face of the island all provide evidence for the presence of this fault (Clements and Emery, 1947, p. 307-313; Norris, p. 61)..$^{25}$

Prominent sets of narrow, nearly vertical joints are present in the thick-bedded sandstone units. The joints, which usually measure less than an inch across, intersect nearly at right angles and are roughly parallel to the two main set of faults.

\section{FOLDS}

The axis of the broad anticlinal fold that forms the main structural feature of San Nicolas Island (pl. 3) is nearly parallel to the long dimension of the island. The fold axis, which is offset by faulting, trends approximately N. $62^{\circ} \mathrm{W}$.; the plunge, although interrupted by faulting, averages about $10^{\circ} \mathrm{SE}$. (pl. 3, structure section $\left.F-F^{\prime}\right)$. To the northwest, the fold axis leaves the shoreline 11/4 miles southeast of Vizcaino Point. Near the east end of the island the fold axis intersects the coast line about half a mile east of Dutch Harbor. Although most of the south limb of the anticline is not exposed, structure sections $A-A^{\prime}$ and $C-C^{\prime}$ (pl. 3) indicate that the fold is nearly symmetrical with slightly steeper dips on the south flank. Observations by geologic divers off the west end of the island suggest that the fold axis bends westward with a trend of approximately N. $75^{\circ} \mathrm{W}$. (pl. 4).

Local minor warping sometimes is present in the thick incompetent siltstone units, and small flexures occur in all the units on the north limb of the main fold (pl. 3), structure section $D-D^{\prime}$.

It is possible that the anticline is truncated to the southeast by the large fault presumed to be present along the northwest margin of the San Nicolas Basin. Reversal in plunge on the anticline, if present, and

\footnotetext{
${ }^{25}$ See footnote 2 , p. 4.
}

the extent of the fold northwest of the island cannot be precisely located from the evidence gathered during the offshore operations. The strike and dip pattern in the offshore area suggests a reversal in plunge of the fold, but the apparent domelike orientation of the strata may result from the displacement of small fault blocks.

The age of the folding is known only in broad terms. Because the faults offset the main fold axis, some of the folding took place before the faulting. As the time of extensive fault movement may have taken place in pre-middle Miocene time and because the age of rocks involved in the folding is Eocene, it may be postulated that folding may have begun in the Oligocene or early Miocene. However, Miocene rocks on San Clemente Island, on Santa Barbara Island, and on the northern Channel Islands are folded, indicating that strata in the San Nicolas Island area may have been further deformed after late Miocene time. Regional folding of post-Miocene age also seems to be reflected by the distribution of forminiferal samples of early, middle, and late Miocene age cored from the Santa Rosa-Cortes Ridge northwest of Begg Rock. ${ }^{26}$ Therefore, it seems likely that several episodes of folding or continuous folding since late Eocene time have affected the structure on San Nicolas Island.

\section{OFFSHORE STRUCTURE OBSERVED BY DIVERS}

The structural data obtained from the offshore stations indicate that the anticlinal structure observed on the island continues seaward west of the island. Both the distribution of a thick trough-forming siltstone unit exposed on the sea floor and the pattern of the strikes and dips confirm the westward extension of the anticlinal structure. Faults offshore seem to have the same pattern and magnitude as those mapped on the island. Because of the lack of continuous bedrock exposures and traceable marker beds and the environmental deterrents imposed upon underwater geologic operations in this area, none of the faults was traced more than a few tens of feet. Only where they have a pronounced effect on the strike and dip pattern and where distinctly different rock types are in juxtaposition are the faults evident to the diver. Some offshore faults can be inferred on the basis of submarine topography and anomalous strike and dip orientations.

Diving operations by Menard and others (1954) off the north and northwest coasts of San Nicolas Island revealed no structural complications on the north limb of the anticline.

\footnotetext{
${ }^{28}$ See footnote 8, p. 4.
} 
One of the critical problems relative to the geologic structure of San Nicolas Island is whether the anticline and its associated faults provide sufficient closure for the accumulation of oil and gas immediately northwest of the island. Although the rather sparse structural data that could be obtained where diving operations were feasible suggest that the anticline may reverse its plunge northwest, the offshore strikes and dips also can be interpreted as indicating anomalous attitudes of the bedding due to faulting. An example of the latter interpretation may be seen in the orientation of the strike and dip pattern on the island immediately north of Dutch Harbor where fault blocks that contain units 6,7 , and 8 produce an apparent domelike structure if the bedding attitudes alone are considered.

\section{PALEONTOLOGY}

\section{EOCENE FORAMINIFERA}

Foraminifera are abundant in many of the siltstone units of Eocene age exposed on San Nicolas Island and adjacent parts of the island shelf. A short statement by M. C. Israelsky regarding these foraminiferal faunas was included in an open-file report of the U.S. Geological Survey (Vedder and others, 1956), and the following descriptions of the microfaunas are revised excerpts from that report.

The measured stratigraphic sections of the Eocene rocks were systematically sampled for Foraminifera, and selected samples from the sea floor off the west end of the island were obtained for microfaunal studies. More than 400 samples were collected, approximately 230 of which have been examined for their fossil content. The Foraminifera were mounted in two sets of slides. The first set shows the relative proportions of the more abundant species in each sample, and the second set has mounted individuals of every species found in each sample.

After a preliminary examination of the slides prepared for relative-abundance studies, it was found that the most abundant groups of species in any individual sample also occur throughout the entire stratigraphic sequence. Therefore, a population study was begun in which the percentage abundance of each species in every sample was plotted on a graph to indicate possible variation in populations throughout the stratigraphic sequence. The results obtained from this method proved unsatisfactory for determining zonation because of the predominance of poorly preserved indeterminate smooth buliminids and chilostomellids.

A second method of zonation based on the percentage relationships of the 10 most abundant species, excluding the smooth buliminids and chilostomellids, produced only 1 significant biostratigraphic boundary in nearly 3,500 feet of section. Below this boundary, Bifarina nuttalli Cushman and Siegfus has the highest abundance of the selected group of Foraminifera. The stratigraphically highest sample in which Bifarina nuttalli occurs is approximately 100 feet below the top of unit 6 in stratigraphic section 3 (pl. 5). This means of zonation suggests a faunal division of the exposed Eocene section on San Nicolas Island into two main parts, consisting roughly of an upper twothirds and a lower one-third.

At the present stage in the investigation, the only common diagnostic species that seems to be restricted in the stratigraphic sequence is Plectina garzaensis Cushman and Siegfus, which occurs only in stratigraphic sections 11 and 12, the uppermost 446 feet of the exposed section (pl. 5).

Many of the Foraminifera from the Eocene rocks exposed on San Nicolas Island also occur in formations of Eocene age on the west side of the San Joaquin Valley and in the Ventura Basin. Comparable forms occur both in the middle part of the Lodo formation (Laiming's C zone: Laiming, 1940, p. 535-568) of early Eocene age and in the Canoas siltstone member of the Kreyenhagen shale (low in Laiming's A-2 zone) of late Eocene age; however, the presence of Amphimorphina californica Cushman and McMasters, which occurs in the upper part of the Llajas formation (Laiming's B-1 A zone) of middle Eocene age, Cibicides sp. (Wilson's Cibicides coalingensis), figured from the Gaviota formation (Laiming's $\mathrm{R}$ zone) and Robulus welchi (Laiming's R, A-1, A-2 zones) indicates that the entire section sampled for Foraminifera on San Nicolas Island is of late middle to late Eocene age. Furthermore, the species mentioned above strongly suggest the age of these strata to be equivalent to that of the Kreyenhagen shale of the San Joaquin Valley.

\section{EOCENE MEGAFOSSILS}

Most geologic reports on San Nicolas Island state that the older sedimentary rocks are barren of megafossils or that they contain only fragmentary oyster shells. Bowers (1890, p. 58) notes the presence of comminuted shell fragments in sandstone at Corral Harbor, and Reed $(1933$, p. 5) cites W. S. W. Kew as having reported Eocene mollusks from San Nicolas Island, but a list of species is not included in either paper. A coral and a few oyster shells were found by Kemnitzer ${ }^{27}$ in the sedimentary rocks designated as units 7 through 11 of this report.

A total of 28 identifiable mollusk species and subspecies were collected from five fossil-bearing locali-

\footnotetext{
${ }^{27}$ See footnote 1, p. 4.
} 
TABLE 3.-Checklist of Eocene mollusks from San Nicolas Island [Identified by J. G. Vedder. $\times$, present as named; cf., similar form, inadequate material for comparison; aff., close affinity but with known difference in detail; ?, identification of species doubtful; ?cf identification of genus doubtful; generic name in quotes, used in a broad or probably incorrect sense]

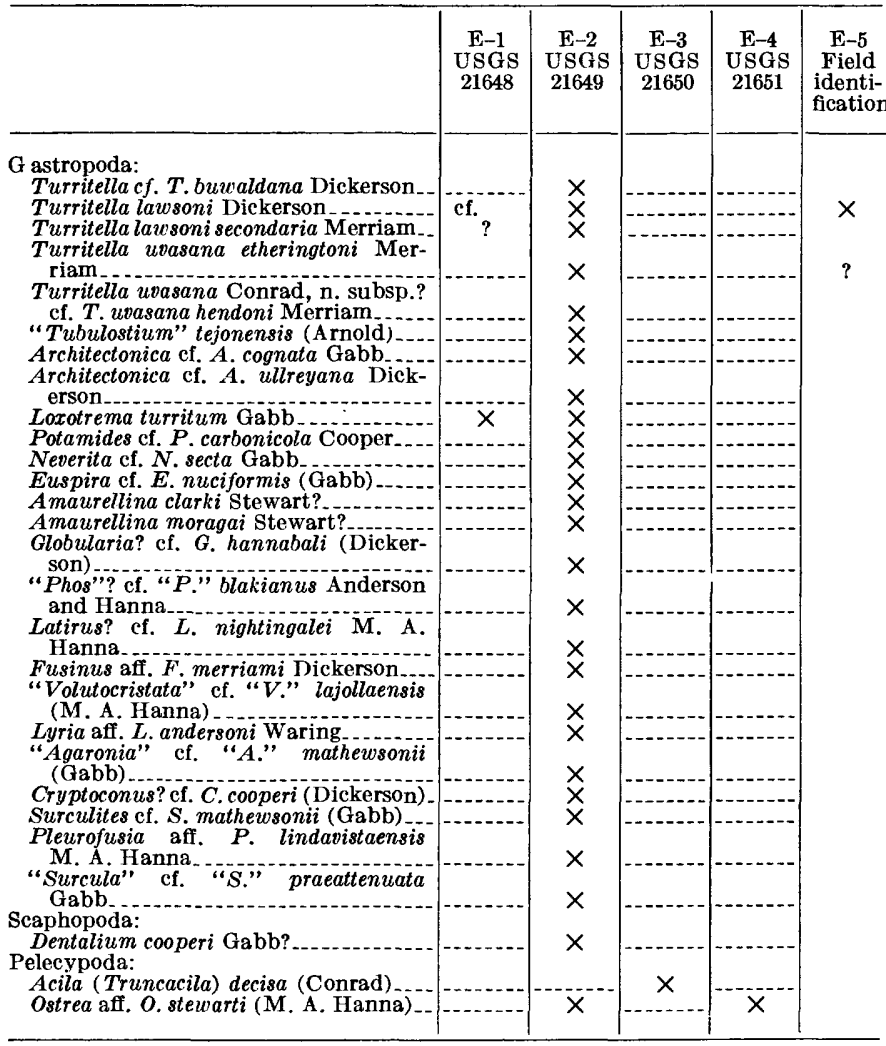

ties during the fieldwork for this report (table 3). The largest assemblage of Eocene megafossils was found in the matrix of pebbly mudstone in unit 10 at locality $\mathbf{E}-2$; it yielded 27 identifiable mollusk forms and 1 coral. Although most of the specimens are incomplete, the sculpture on the shells usually is well preserved. Elsewhere only 1 to 3 species were found at each of the other 4 localities. Descriptions of the Eocene fossil localities are given in table 8 .

The bulk of the specific determinations suggest an age assignment of middle to late Eocene on the basis of forms presumed to be conspecific with those commonly found in the Domengine formation, the upper part of the Llajas formation, the Rose Canyon shale member of the La Jolla formation, and the Tejon formation, all of which are considered by most paleontologists to represent the upper half of the Eocene in California.

\section{FOSSILS FROM MARINE TERRACE DEPOSITS}

More than 250 identified species and subspecies of marine mollusks and other invertebrates were collected from 16 localities distributed over 11 of the 14 terrace platforms evident on San Nicolas Island (table 4). The platforms range in altitude from 20 to 900 feet above sea level (pl. 2). These 16 collections represent the most complete sequence of fossil assemblages from successive terrace levels in southern California and contain the largest faunas reported from terrace levels higher than 500 feet. The overall vertical range, however, does not rival that found in the Palos Verdes Hills, where terrace fossils have been found at an altitude of 1,215 feet (Woodring and others, 1946, p. 93-95).

Descriptions of the Pleistocene fossil localities are given in table 9 .

Foraminifera, Bryozoa, and calcareous algae are abundant constituents of some of the fossil assemblages but have not been identified. Provisional determinations by the senior author have been made for brachiopods, echinoids, corals, and barnacles, but no attempt has been made to identify the less common decapod crustacean fragments. Vertebrate material including bird, sea lion and seal, walrus (?), and sea otter (?) was collected at four localities, one of which has been described by Howard (1955, p. 135-143) in a paper on a new species of diving goose. Specific determination of the poorly preserved and fragmentary fossil vertebrates has not been made for this report.

Several early records mention fossil marine invertebrate faunas from the terrace deposits of San Nicolas Island, but little has been published since Cooper's short list of 1894 (Cooper, 1894, p. 24-32). A brief chronological summary of the published and unpublished data on Pleistocene fossils from San Nicolas Island is as follows:

1865. Cooper, J. G., in Whitney, J. D., Islands off the coast of southern California: California Geol. Survey, Geology, v. 1 , chap. 6 , sec. 5 , p. $182-186$.

Describes raised beaches on which were found "*** shells of existing species. *** all of a rather northern type."

1888. Cooper, J. G., Catalogue of Californian fossils : California State Mining Bur. 7th Ann. Report of the State Mineralogist for the year 1887, p. 223-308.

Includes six forms from the "Quaternary (postPliocene)" on San Nicolas Island. Listed are 5 marine gastropods and 1 land snail, but the collector and locality are not given.

1890. Bowers, Stephen, San Nicolas Island: California State Mining Bur., 9th Ann. Report of the State Mineralogist for the year 1889 , p. 57-61.

The author lists 39 invertebrate forms at a locality presumed to be the same as $\mathrm{SN}-1$ of this report. The list includes 27 marine gastropods, 8 pelecypods, 1 chiton, 1 echinoid, and 2 land snails.

1894. Cooper, J. G., Catalogue of Californian fossils : California State Mining Bur. Bull. 4, 65 p.

A distributional list including seven additional invertebrate forms from the "Quaternary" of San Nicolas Island. Listed are 5 marine gastropods, 1 chiton, and 1 echinoid collected by Stephen Bowers at an undescribed locality. 
pre-1900(?). A previously unreported collection by Henry Hemphill containing 25 marine mollusks presumably was found in the vicinity of $\mathrm{SN}-12$ of this report. The collection was made available for study by Leo G. Hertlein of the California Academy of Sciences.

1938. Cockerell, T. D. A., Studies of island life: Colorado (Univ.) Studies, v. 26, no. 1, p. 3-20.

A list of 13 molluscan species from an altitude of between 400 and 500 feet is recorded, which includes 11 marine gastropods and 2 pelecypods. Identifications were made by Myra Keen.

1940. Cockerell, T. D. A., The marine invertebrate fauna of the Californian islands: Pacific. Sci. Cong. 6th, Berkeley, Palo Alto, and San Francisco, Calif., 1939, Proc., v. 3, p. 501 .

A supplemental list to the report of 1938 includes 11 species of gastropods and 3 pelecypods identified by Myra Keen.

1950. Thirty-one species of marine invertebrates are listed in an unpublished report by George Kanakoff of the Los Angeles County Museum. The fossils were referred to the museum for identification by R. M. Norris. This locality is the same as $\mathrm{SN}-14$ of this report.

1955. Howard, Hildegarde, New records and a new species of Chendytes, an extinct genus of diving geese: The Condor, v. 57, no. 3, p. 135-143.

Describes bird bones and records marine mammal and fish remains originally collected by $R$. M. Norris and $K$. S. Norris from a marine mollusk locality that is the same as $\mathrm{SN}-14$ of this report.

\section{ANNOTATED CHECKLIST}

A checklist of fossils from terrace deposits of Pleistocene age on San Nicolas Island (table 4) has been prepared for each locality at which fossils were collected on San Nicolas Island. Included with the identifications are the approximate altitude of the localities, new records of species not previously reported from sediments of Pleistocene age, notes on variation of certain species from the typical form, and forms not known to be living. The recorded geographic ranges of living forms that presumably are distributed only north or south of the latitude of the island, together with forms that now live close to their northern or southern limits in the latitude of the island, also are noted. ${ }^{28}$ The recorded bathymetric ranges of forms that now presumably inhabit only depths from 10 to 100 fathoms or more than 100 fathoms off southern California also are included on this list, but the depth ranges of mollusks that now are widely dispersed from littoral through sublittoral depths (Hedgpeth, 1957, p. 94, fig. 1) are not shown. Some of the species that are cited as living in 10 to 100 fathoms off southern California live in shallower water northward and are found in a littoral environment in the colder surface waters from northern California to Alaska (for example, Pupillaria pupilla, Ceratostoma foliatum).

${ }^{28}$ New fossil records, notes on forms not known to be living, and geographic and bathynetric range data are based on reports published before November 1959 .
A serious limitation in using published bathymetric data is that the reported findings are inadequate for conclusive evidence of depth range, as further dredging and collecting by divers may extend the depth ranges of many mollusks, particularly the small forms. An additional shortcoming of the geographic and bathymetric ranges given on the checklist is that the Recent fauna around San Nicolas Island is relatively unknown, and future collecting in the area may reveal some range extensions. Furthermore, the geographic position of the island is such that the composition of the living fauna probably does not exactly correlate with mainland coast faunas at the same latitude because of upwelling cold water in the vicinity of the island (Sverdrup, Johnson, and Fleming, 1942, p. 724 725; Orr and others, 1958, p. 929).

\section{PALEORCOLOGIC INFERENCES HABITAT}

The bulk of the molluscan species from each terrace platform can be assigned to the rock-cliff and tide-pool facies (Woodring, 1935, p. 297; Woodring and others, 1946 , p. 93) or, less specifically, to the intertidal opencoast and protected outer-coast habitats (Ricketts and Calvin, 1952, p. 6-7). Associated with the rock-cliff and tide-pool forms are many sublittoral species that now live below low tide on a rocky substrate, several species that exist in widely varied habitats, and a few offshore forms. The same depositional environments, which are indicated by the composition of the fossil assemblages, occur along the coast of San Nicolas Island at the present time. Because bedrock types similar to those now being cut were being eroded by the Pleistocene seas, it is reasonable to assume that the character of the coastline and the gradient of the wave-cut benches around the island were essentially the same as now. Shoreline features including short sandy beaches separated by broad, but not projecting, headlands and a sea floor with a rather steep slope can be inferred from the configuration of the ancient sea cliffs, the gradient of the terrace platforms, and the composition of the terrace faunas.

\section{ANOMALOUS OCCURRENCE OF RESTRICTED-DEPTH FORMS}

The presence at several fossil localities of one or more forms that are now most commonly found at a depth of 10 to 100 fathoms off coastal southern California (for example, Puncturella cooperi, Bursa californica. Barbarofusus kobelti) or that sometimes range into depths greater than 100 fathoms (for example. Boreotrophon stuarti, "Progabbia" cooperi. Cyclocardia longini) can be attributed to several causes or to a combination of causes. Collections at $\mathrm{SN}-1$, $\mathrm{SN}-2$, and $\mathrm{SN}-3$, were made on steeply sloping terrace platforms at some distance from the associated sea 
cliff, suggesting that these deposits may have accumulated at depths of as much as 10 fathoms. Arbitrary platform gradients adopted by Davis (1933, p. 1057) for the offshore area of the Santa Monica Mountains indicate that the platform depth below sea level ranges from 50 feet $1 / 4$ mile offshore to 85 feet at a distance of $1 / 2$ mile, except in the area east of Point Dume where the gradient increases 25 to 33 percent. Off the south coast of San Nicolas Island the gradient is even greater; $1 / 4$ mile south of Seal Beach the depth is 60 feet, and at $1 / 2$ mile, 150 feet. Forms common in the deeper parts of the inner sublittoral zone thus might be expected in terrace deposits at the outer edge of platforms with steep gradients. In addition, a combination of storm waves and unusually strong tidal current occasionally carries outer sublittoral forms into littoral zones. Uprooted kelp holdfasts often transport inner sublittoral forms to shore. Another remote possibility for transport of minute species is provided by bottom-feeding fish which may deposit fecal pellets containing deep-water shells in areas of shallow water. Furthermore, it is possible that some of the organisms now living only in the deeper sublittoral zone may have been able to tolerate more adverse conditions in Pleistocene time, such as greater wave impact, coarser substrate, or the greater temperature differential of shallow water. Perhaps, during different episodes of terrace cutting, regional wave action was diminished and surface-water temperatures were locally less variable, allowing some delicate forms to move into shallow water.

Bay and estuarine or mudflat habitats are not represented in the faunal composition of any terrace deposit on San Nicolas Island, although a few individuals commonly associated with these environments are present at some localities (for example, Panope generosa, Saxidomus nuttalli, Schizothaerus nuttalli). A few occurrences of forms usually considered indicative of a protected sandy-beach or offshore sandybottom habitat (for example, Spisula planulata, Trigoniocardia biangulata, Tellina salmonea) may be attributed to the existence of extensive sandspits such as the one now present at the east end of the island, or to the fact that a few forms generally regarded as indicators of a restricted habitat sometimes live in other seemingly adverse environments.

\section{RELATIVE SURFACE WATER PALEOTEMPERATURES}

Conclusions regarding the relative paleotemperatures of the surface sea water during the cutting of individual terraces must be drawn with reservations when based on faunal compositions. It is well established that both northern and southern shallow-water species occur in the same beds in Pleistocene strata at a number of localities in southern California and northwestern Baja California (Woodring and others, 1946 , p. 95-96; Bruff, 1946, p. 221-222; Valentine, 1955 , p. 465 ; Emerson, 1956a, p. 326-327; Emerson, $1956 \mathrm{~b}$, p. 396-397). To relate temperatures inferred from faunal compositions to definite glacial or interglacial stages, with their resulting isothermal shifts, is problematical even where local Pleistocene and Recent marine mollusks and their ecology are well known (Woodring and others, 1946, p. 100-103). However, Valentine and Meade (1958, p. 57) suggest that a good correlation exists between oxygen isotope estimates of paleotemperatures and those inferred from zoogeographic methods applied to well-known Pleistocene localities in California. Therefore, it is reasonable to assume that the composition of the large terrace faunas on San Nicolas Island is a fairly accurate indicator of relative surface water paleotemperatures.

The constituents of the faunal assemblages (collections of more than 65 molluscan species) from selected terrace platforms that suggest relatively cooler surface water at the time of high-terrace cutting and relatively warmer surface water at the time of low-terrace cutting based on present geographic ranges are listed in table 5. Three fossil localities ( $\mathrm{SN}-1, \mathrm{SN}-12, \mathrm{SN}-$ 13) from the 100-foot terrace yielded a total of 150 molluscan species (excluding terrestrial gastropods, chitons, scaphopods, and pyramidellids), of which 6 now live south of San Nicolas Island on the mainland coast (lat $33^{\circ} 14^{\prime} 30^{\prime \prime} \mathrm{N}$ ) and 11 now occur only near the northern limit of their recorded geographic ranges at this latitude. The same collections contain 6 forms that now range entirely north (on the mainland coast) of the latitude of the island and $\mathbf{1 5}$ forms that now live near the southern extreme (on the mainland coast) of their recorded geographic ranges in the latitude of the island. Two localities ( $\mathrm{SN}-2, \mathrm{SN}-3$ ) that yielded large assemblages (more than $140 \mathrm{~mol}-$ luscan forms excluding terrestrial gastropods, chitons, scaphopods, and pyramidellids) from the 775-foot terrace contain only 3 small forms that supposedly now live south of the latitude of the island and 5 forms that now are reported to live near their northern limits at lat $33^{\circ} \mathrm{N}$. From the same collections, 11 forms were obtained that are reported to live entirely north (on the mainland coast) of the latitude of San Nicolas Island and 15 forms that now are recorded as living near their southern limit (on the mainland coast) in this latitude. None of the intermediate terrace deposits contain large enough faunas for significant paleotemperature estimates, although two of the larger assemblages are listed in table 5 for comparison. 
Table 4. - Checklist of fossils from terrace

IIdentified by J. G. Vedder; land snails from locality SN-1 and chitons from localities SN-1 and SN-3 identified by A. G. Smith, but with known difference indetail;?,identification of species doubtful; ?cf. or ?sp., identification of genus doubtful; unidentified; *, collected by Henry Hemphill; $X($ ?), probable locality of Hemphill's collection; (?), end point of geographic

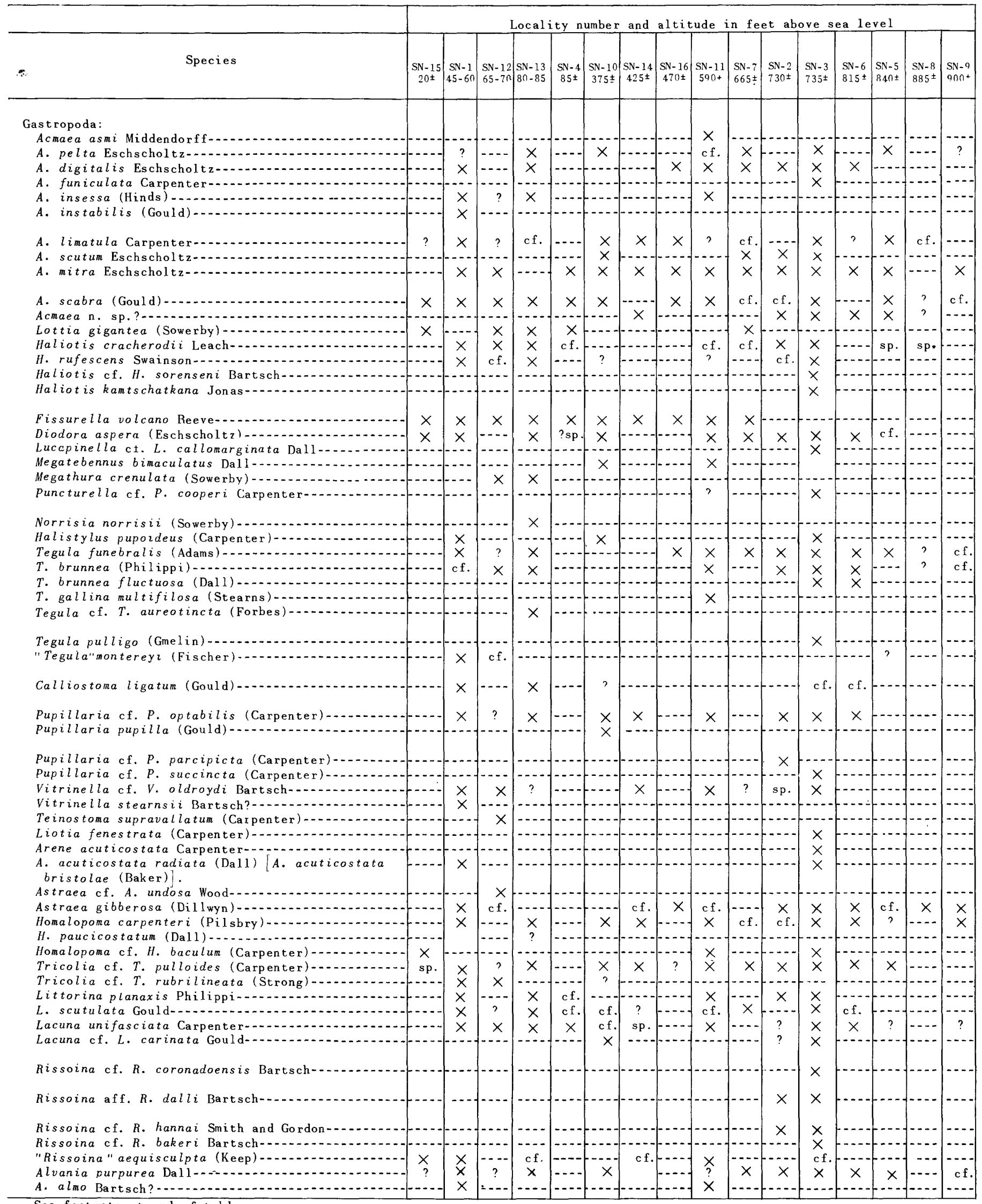

See footnote at end of table. 
deposits of Pleistocene age on San Nicolas Island

California Academy of Sciences. $X$, present as named; cf., similar form, inadequate material for comparison; aff., close affinity quotation marks around generic name indicate the designation is used in a broad or probably incorrect sense; sp., species range doubtful; $X(2)$ number of unidentified species present]

Remarks

Forms not known to be living, new fossil records ${ }^{1}$, and variant forms

\begin{tabular}{|l}
\hline \\
\hline
\end{tabular}

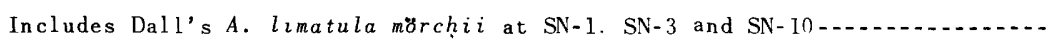

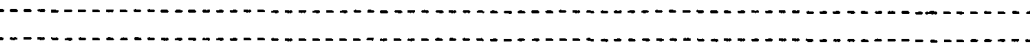

This form may be a variant of $A$ scabra (Gould This for.

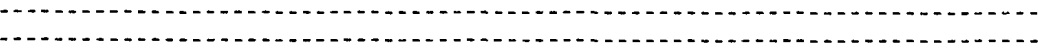
Thicker spired than typical form. Not previously reported as fossili.... Thicker shelled and more coarsely sculptured than typical form. Not previously reported as fossil ${ }^{1}$.

\begin{tabular}{|l}
-1 \\
\hline
\end{tabular}

19.2

-

(1)

Includes a high-spired variant with the typical form at SN-3-1.......... Crescent City, Calif., to Santa Barbara Islands.

. Crescent City, Calif., to San Nicolas Island.

Island, Baja Islands, Calif., to Santa Margarita

Includes a form with a narrow shoulder and faint oblique axial ribs at

$\mathrm{SN}-1$.

(19.

(2.

1.

Smaller than typical form

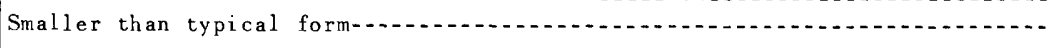

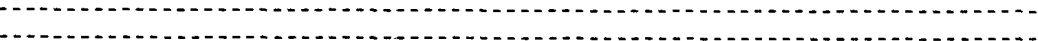

10.

Fragments show a well-developed double peripheral keel-a

Coarsely sculptured form with heavy axial ribs, operculum typical............

Coren

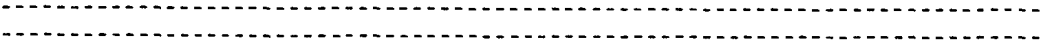

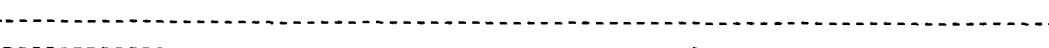

(1)

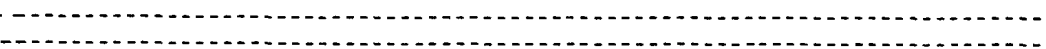

Shows an inflated whorl profile similar to that of R. keenae Smith and

Gordon and $R$. bakeri Bartsch but is larger and thicker shelled.

Larger and more inflate than typical form. Sculpture similar to that of $R$. hannai Smith and Gordon.

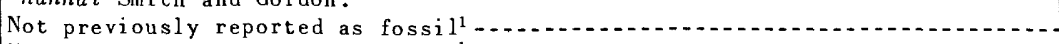

Not previously reported as fossil $1^{1} \ldots \ldots \ldots \ldots \ldots$

(1)

0
0
Recorded geographic ranges only for forms now living north or south of latitude of San Nicolas Island or close to their northern or southern limits. Depth ranges only for forms restricted to deep sublittoral zones off southern California ${ }^{2}$

Diego(?).

Rare south of Santa Barbara.

y in areas of intense upwelling south of San Pedro.

Sitka, Alaska, to Redondo Beach, Calif.; rare south of Monterey.

ff Redondo Beach, Calif., in 25-75 fathoms. Alaska to San Diego.

Island, Baja Calif.

Bolinas Bay, Calif., to Santa Barbara Islands.

Kodiak Island to San Diego; rare south of Port San Luis Obispo.

univak Island to San Pedro. Off Redondo Beach in 50 fathoms.

Monterey to Coronado Islands, Baja Calif.

San Pedro, Calif., to the Gulf of California.

ugu Lagoon, Calif., to Cedros Island, Baja Calif. Vancouver to San Diego.

Bering Sea(?) to San Diego(?); rare south of Cayucos. Calif.

Catalina Island to San Martin Island, Baja Calif.

Known only from Carmel Bay, Calif., in 25 fathoms, Catalina Island to Todos Santos Bay, Baja Calif. 
Table 4.-.Checklist of fossils from terrace

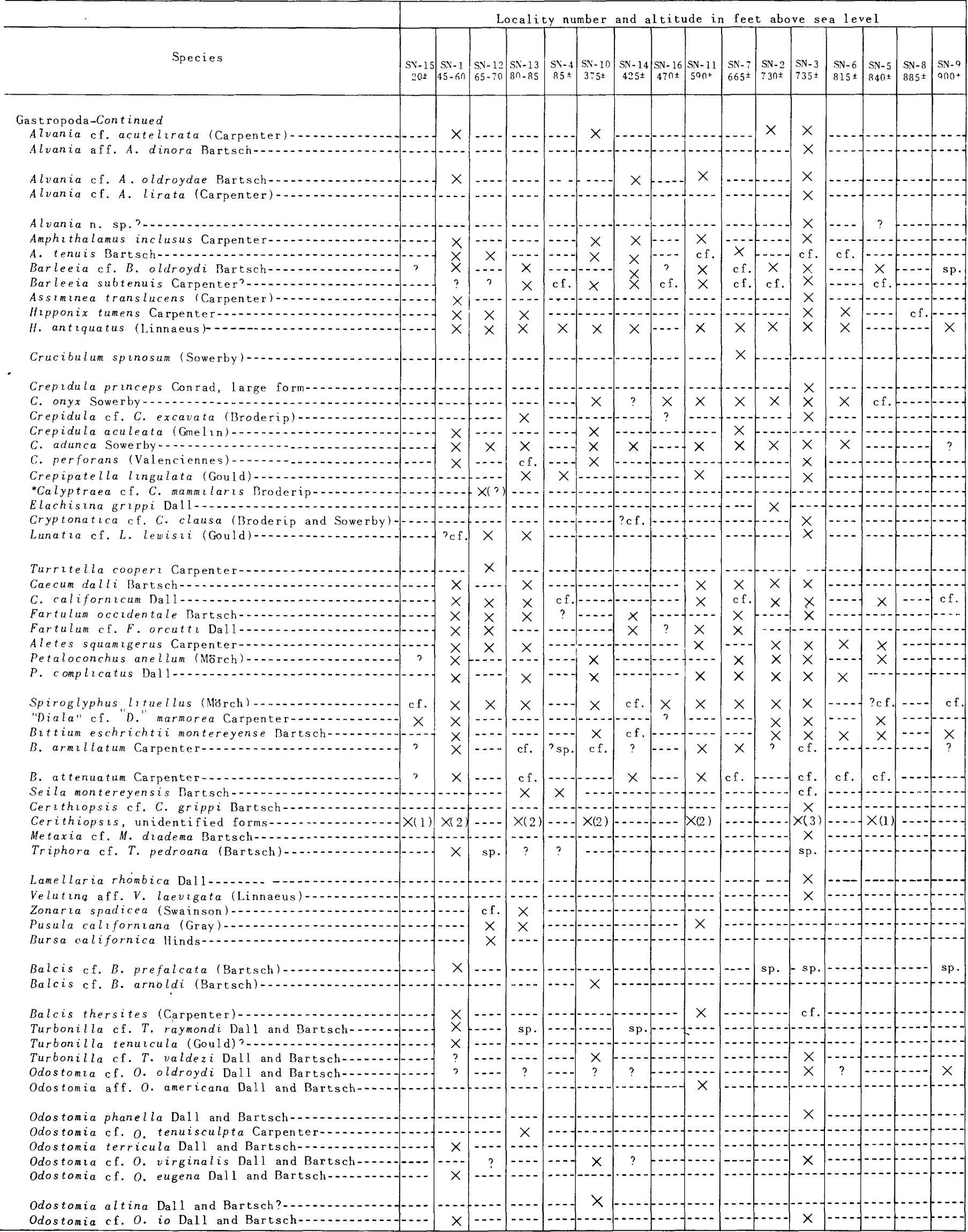

See footnote at end of table. 
deposits of Pleistocene age on San Nicolas Island-Continued

Remarks

Forms not known to be living, new fossil records ${ }^{1}$, and variant forms

Recorded geographic ranges only for forms now living north or south of latitude of San Nicolas Island or close to their northern or southern limits. Depth ranges only for forms restricted to deep sublittoral zones off southern California ${ }^{2}$

Larger and thicker shelled than typical form. Sculpture similar to that of A. dalli Bartsch. Not previously reported as fossil.

Smaller and more elongate than typical form-..............

Lacks the prominent nodes below the suture shown on the typical form--

Resembles $A$. dalli Bartsch but has fewer spiral cords... Renember. May inchu May include $B$. hal zotiphila Carpenter and other forms at SN-3, SN-10, SN-11Include Includes the variant $H$. antiquatus craniodes Carpenter with typical form at $\mathrm{SN}-1, \mathrm{SN}-2, \mathrm{SN}-3$.

Not known to be living ${ }^{1}$. Rare in strata of late Pleistocene age

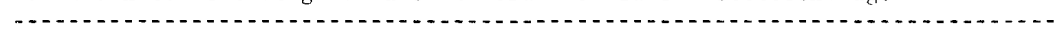

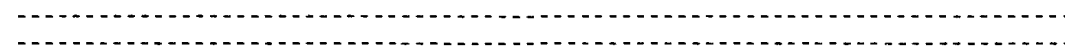

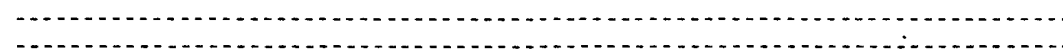

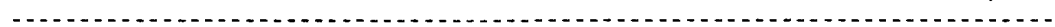
Larger and thicker shelled than C. fastiguata Gould or C. contorta Carpenter: Not previously reported as fossil 1 Not previously reported as fos 1
-12 1.2. 1. (..2. (1)

The typical form seems to intergrade with "D." acuta Carpenter at $\mathrm{SN}-3-\mathrm{C}_{0}$ 10.0

Elogate strongly noded forms with a strong cord above the suture from SN-1 may be $B$. catalinense Bartsch.

0
-120 This sher This shell may be a northern variant of $M$. convexa (Carpenter) This shel1 may be a nor

Outer lip more flaring than typical; sculpture subdued. Outer lip nore flaring than typical (1)

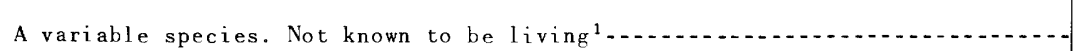
Resembles $B$. berryi (Bartsch) but has heavier callus and lacks doubly reflexed spire. Not known to be living ${ }^{1 .}$

Smaller than typical form. Not previously reported as fossil

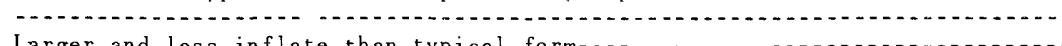
Larger and less inflate than typical form
Coarser sculpture than typical. Not previously reported as fossil More elongate and with more prominent spiral lines than typical. Not previously reported as fossili.

Smaller than typical form--

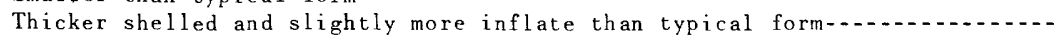
Thick-shelled variants with coarse sculpture at $\mathrm{SN}-3$ Smaller than typical form

Smaller than typical form. Not previously reported as fossil 1
Forrester Island, Alaska.

Guadalupe Island, Baja Calif. (?), to the Gulf of California.

San Pedro to the Gulf of California.

Rare north of southern California; ranges south to Tome, Chile.

San Pedro(?) to Panama.

Magdalena Bay, Baja Calif., to Peru.

Known only from San Diego in $16-20$ fathoms.

Duncan Bay, British Columbia, to Todos Santos May, Baja Calif.

Off southern California in $10-50$ fathoms.

Off Coronado Islands, Baja Calif., in 14 fathoms.

San Pedro to Maz^tlan.

Found off California only in moderate depths

(20-25 fathoms).

Forrester Island, Alaska, to San Diego.

Redondo Beach, Calif., to San Geronimo Island, Baja Calif.

Icy Cape, Arctic Ocean, to Cayucos, Calif.

Off Catalina Island and Redondo Beach in

$15-55$ fathoms.

Monterey to Coronado Islands, Baja Calif.

Redondo Beach, Calif., to Point Abreojos, Baja Calif.

Monterey and Pacific Grove.

Monterey to Coronado Islands.

Redondo Beach, Calif., to Point Abreojos; Baja Calif. Redondo Beach, Calif., to San llipolito Point, Baja Calif.

Known only off San Diego in deep water. 
Table 4.-Checklist of fossils from terrace

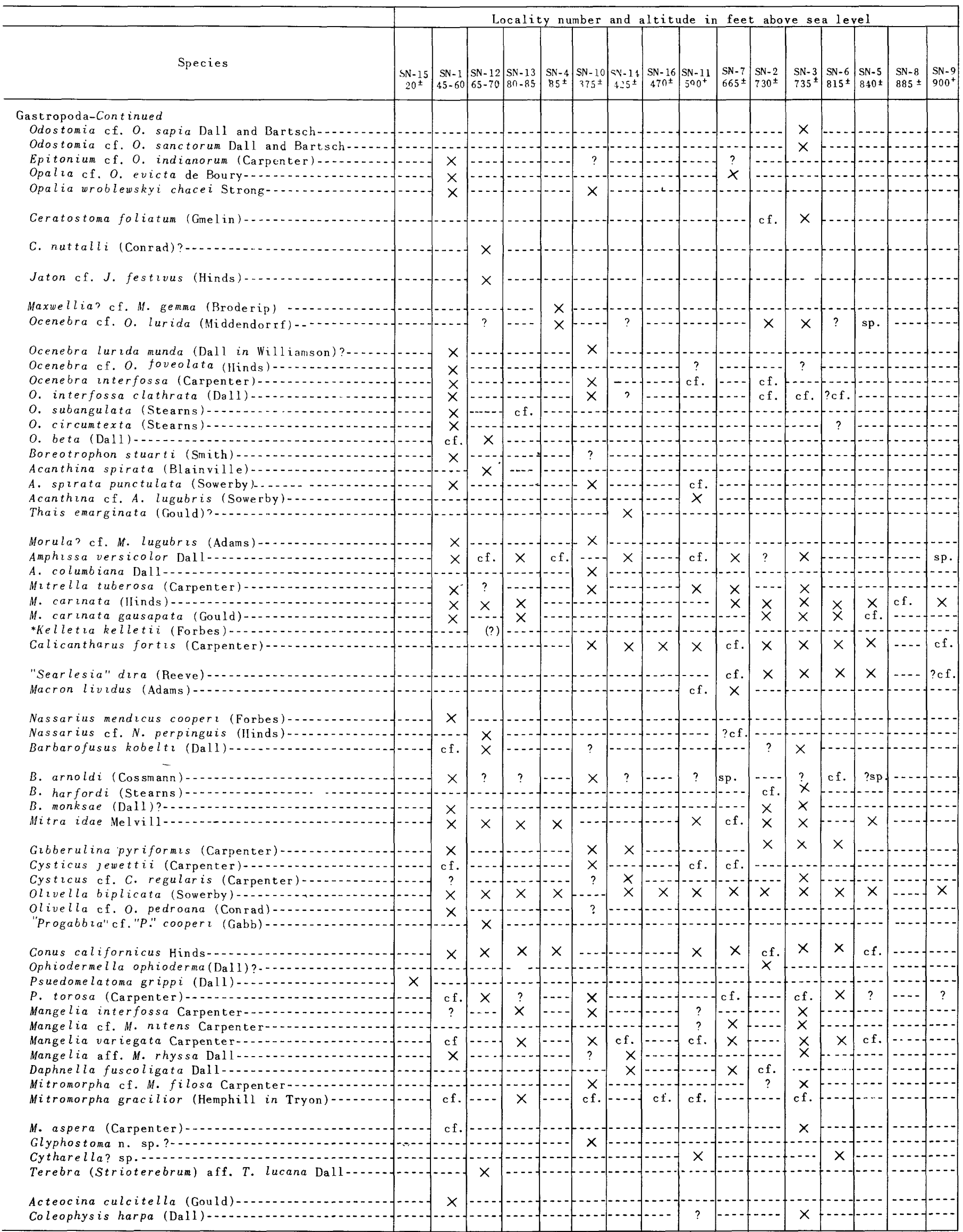

See footnote at end of table. 
deposits of Pleistocene age on San Nicolas Island-Continued

Remarks

Forms not known to be living, new fossil records ${ }^{1}$, and variant forms

Not previously reported as fossil1

Not previously reported as fossil (2.

10.

1
1

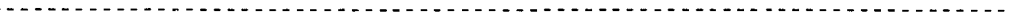

-

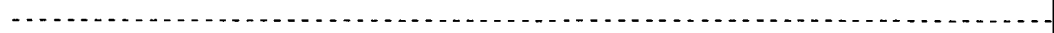

-

Not previously reporteg as fossi

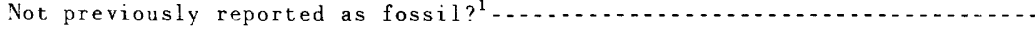

Thicker shelled and with more varices than typical form

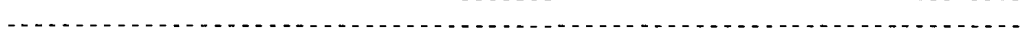

Round-shouldered short-spired small form that may be $T$. emarginata ostrina Gould

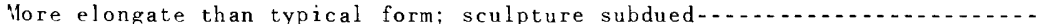

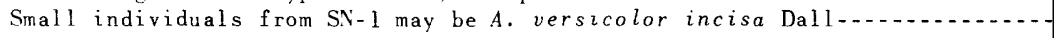

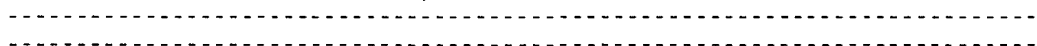

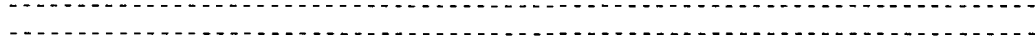

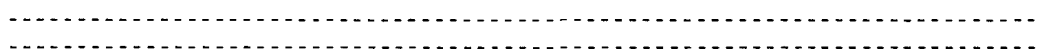

Not known to be living ${ }^{1}$. A strongly sculptured form occurs at $\mathrm{SN}-2, \mathrm{SN}-3$,

SN-5, SN-10, SN-11. Rare in late Pleistocene.

Large individuals at SN-3 are very close to "Fusus" portolanesis Arnold....

(19-1

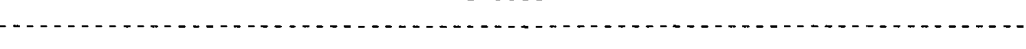

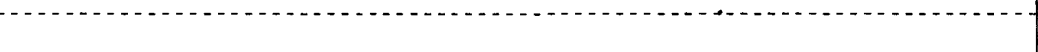

Not previously reported as fossil ${ }^{1}$

A short-spired round whorled form ( $M$. idae montereyi Berry) occurs with

the typical at $\mathrm{SN}-1$

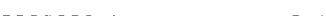

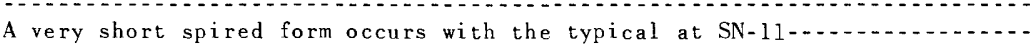

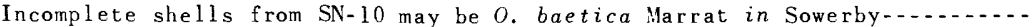

Incomplete shells from SN-10 may be O. baetica Marrat in Sowerby-

Not previously reported as fossil

Variable shape and sculpture on forms from SN-1-1.

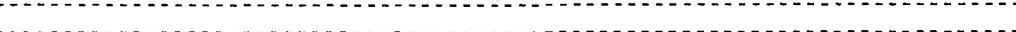

Extremely variable in shape and ornamentation

Longer aperture and body whorl than typical form

More robust and slightly coarser sculptured than typical form-

Shells from SN-11 and SN-14 may be intergrades between $M$. filosa and

M. gracilior

May be a variant of G. conradiana (Gabb)

Thicker shelled, shorter spired, and slightly larger than typical form;

fewer spiral cords.

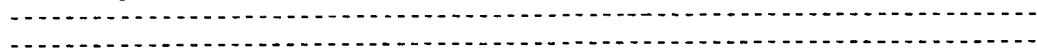

Recorded geographic ranges only for forms now living

north or south of latitude of San Nicolas Island or

close to their northern or southern limits. Depth

ranges only for forms restricted to deep sublittoral zones off southern Californi $a^{2}$

Known only from San Diego.

La Jolla, Calif., to Magdalena Bay, Baja Calif.

Depoe Bay, Oregon, to Catalina Island in 50 fathoms.

San Diego (?).

Sitka, Alaska, to San Pedro in 20-35 fathoms. San

Di ego( ?).

Point Conception, Calif., to Magdalena Bay, Baja

Calif. Monterey(?).

Santa Barbara, Calif., to San Ignacio Lagoon, Baja Calif.

Forrester Island, Alaska, to Catalina Island in 30 fathoms.

Middleton Island, Alaska, to San Diego, Calif.

Monterey to Catalina Island.

Half Moon Bay, Calif.,to Coronado Islands, Baja, Calif. Shumagin Is lands, Alaska, to San Diego in deep water.

San Diego(?), Todos Santos Bay, Baja Calif, to Panama.

Redondo Beach, Calif., to Panama.

Chiachi Islands, Alaska, to San Pedro.

Chirikof Island, Alaska, to Monterey.

Rare north of San Pedro, south to Point Abreojos,

Baja Calif.

Puget Sound to Todos Santos Bay, Baja Calif.

Monterey(?) to San Diego; off Catalina Island in $30-60$ fathoms.

Coast of Mendocino County.

Farallon Islands to San Diego.

Monterey to Coronado Islands. Off Redondo Beach in 35 fathoms and San Pedro in 123 fathoms.

Forrester Island, Alaska, to Catalina Island.

La Jolla, Calif., to Gulf of California.

Santa Margarita Island to Cape San Lucus, Baja Calif. 
Table 4.-Checklist of fossils from terrace

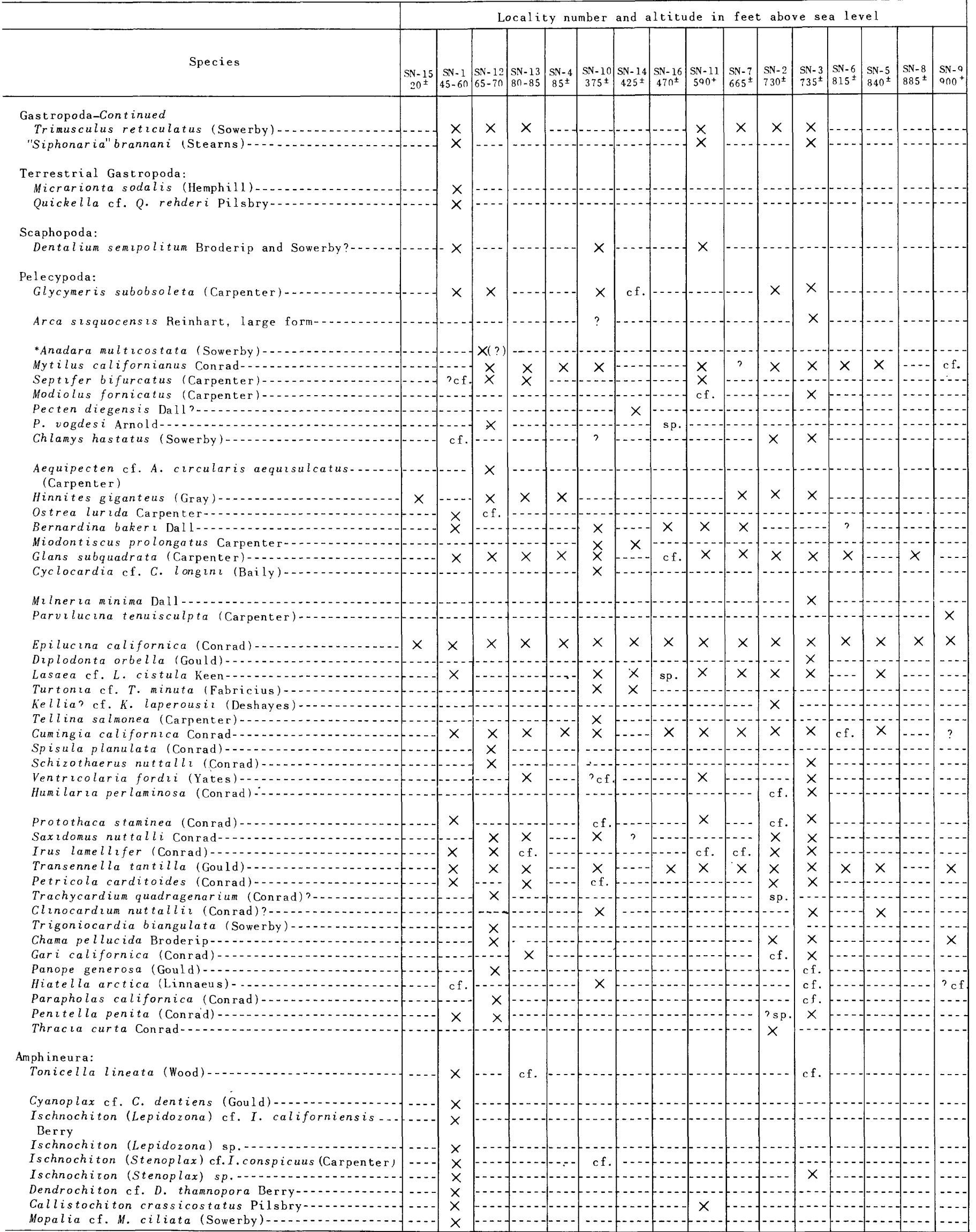

See footnote at end of table. 
deposits of Pleistocene age on San Nicolas Island-Continued

Forms not known to be living, new fossil records 1, and variant forms

Small shells assignable to $G$. corteziana Dall $[?=G$. migueliana Dall] are present at $\mathrm{SN}-1, \mathrm{SN}-3, \mathrm{SN}-10, \mathrm{SN}-11$.

Not known to be living. Length from 3.0 to $65.5 \mathrm{~mm}$; type measures $15.4 \mathrm{~mm}$ and may be an immature individual.

-

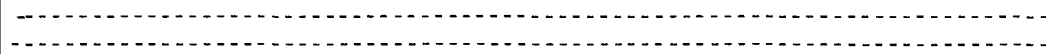
-

The northern form $C$. hastatus hericius (Gould) occurs with the typical form at $\mathrm{SN}-3$.

Not previous ly Not previously reported as fossil More ribs than typical form. Fewer ribs and hi More ribs than typical form. Fewer ribs and higher shell than $C$. barbarensis (Stearns). Not previously reported as fossill'.

Not previously reported as fossi $1^{1}$

Not previously reported as fossil

年 -1
-12 -

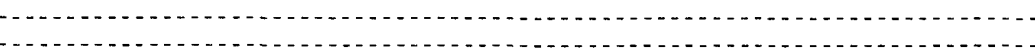
Not known Not known to be living ${ }^{1}$. Not previously reported from strata of late Pleistocene age.

Extremely heavy-shelled forms occur at SN-3-1.

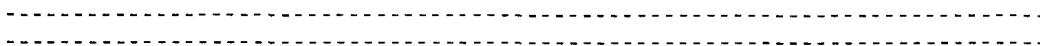

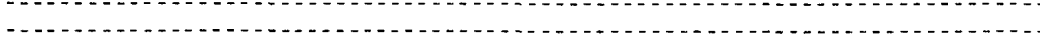
10.

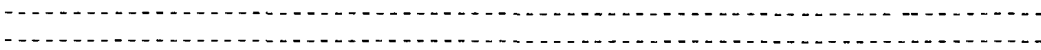
-

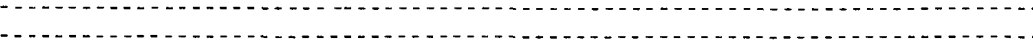
-

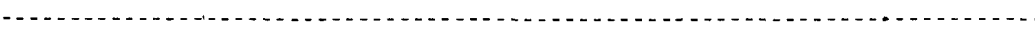
Not previously reported from strata of Pleistocene age in California$$
\text { Not }
$$

Not previously reported as fossil?

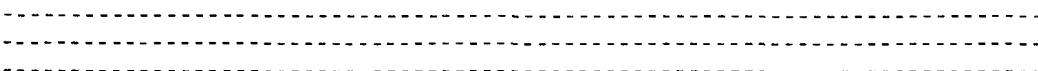

Not previously reported as fossil ${ }^{1}$ Not previously reported as fossi
Recorded geographic ranges only for forms now living north or south of latitude of San Nicolas Island or close to their northern or southern limits. Depth ranges only for forms restricted to deep sublittoral zones off southern California ${ }^{2}$

Newport Beach, Calif.(?), to Panama.

Trinidad, Calif., to San Pedro and Cortes Bank.

Punta Eugenia, Baja Calif., to Päita, Peru. Monterey to San Diego; off Redondo Beach in 25-50 fathoms and 123 fathoms off San Pedro.

Point Loma, Calif, to Magdalena Bay, Baja Calif. Middleton Island, Alaska, to San Diego.

Off Catalina Island in 50-300 fathoms.

Nunivak Island, Alaska, to Coronado Islands,

Baja Calif.

Aleutıan Islands to Coronado Islands, Paja Calıf.

Off southern California in $20-69$ fathoms.

Monterey to San Diego.

Bering Sea to San Diego.

Redondo Beach, Calif., to Guayaqual, Ecuador.

Aleutian Islands to San Diego.

Coos Bay, Oregon, to San Diego.

Chirikof Islands, Alaska, to San Diego.

Aleutian Islands to San Luis Obispo County and San Diego(?).

Forrester Island, Alaska, to San Diego. 
Table 4.--Checklist of fossils from terrace

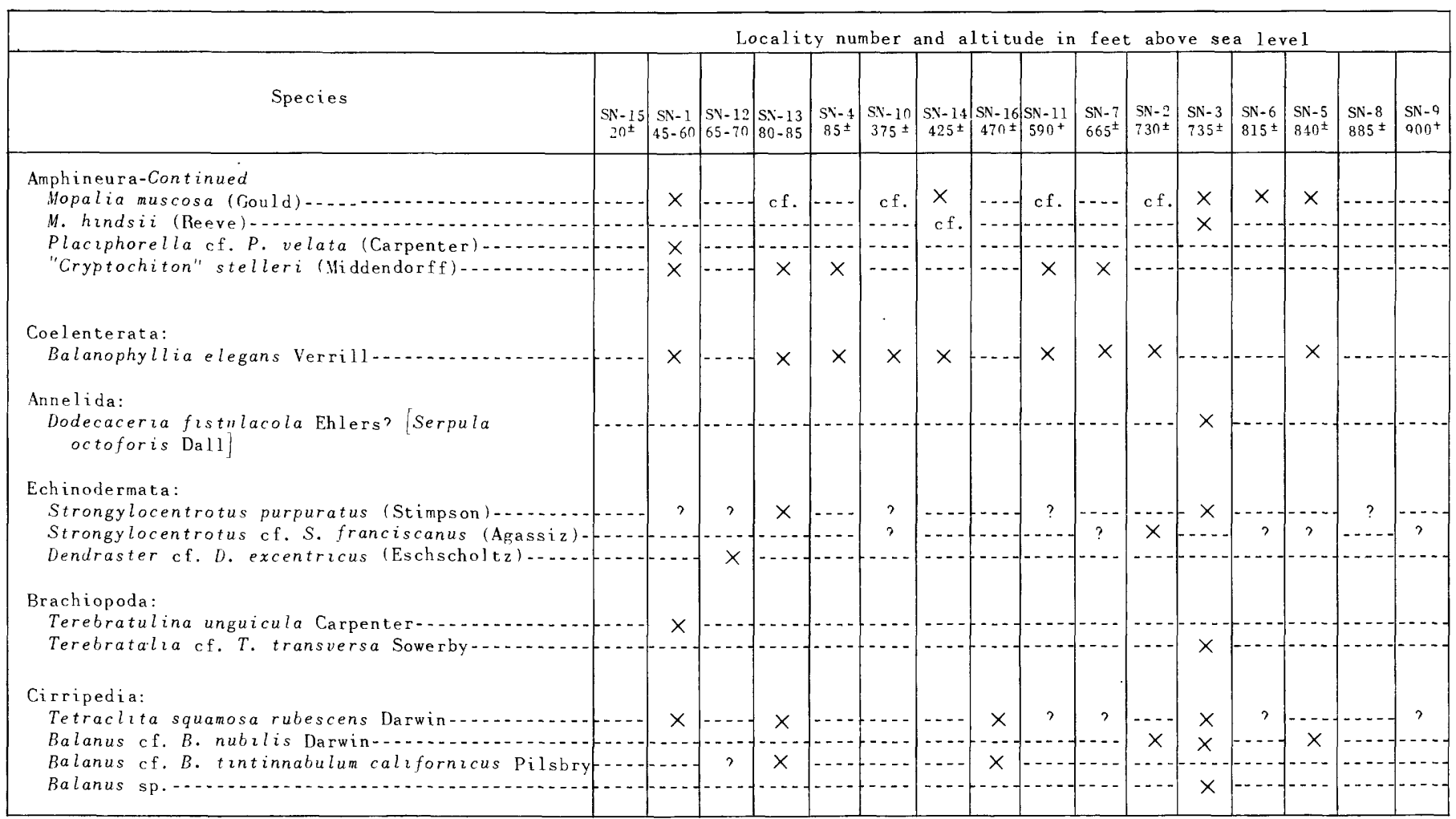

${ }^{1}$ These records compiled from reports issued before November 1959.

${ }^{2}$ Sources of geographic and bathymetric range data: Bormann (1946), geographic range of some species of Ocenebra; Burch ( 1957), bathymetric ranges supplementary to Burch (1944-46); Dall (1921), geographic ranges of Amphineura; Dall and Bartsch Keen (1937), range data not included in Burch (1944-46); Smith and Gordon (1948), range data supplementary to Burch (1944-46); 
deposits of Pleistocene age on San Nicolas Island-Continued

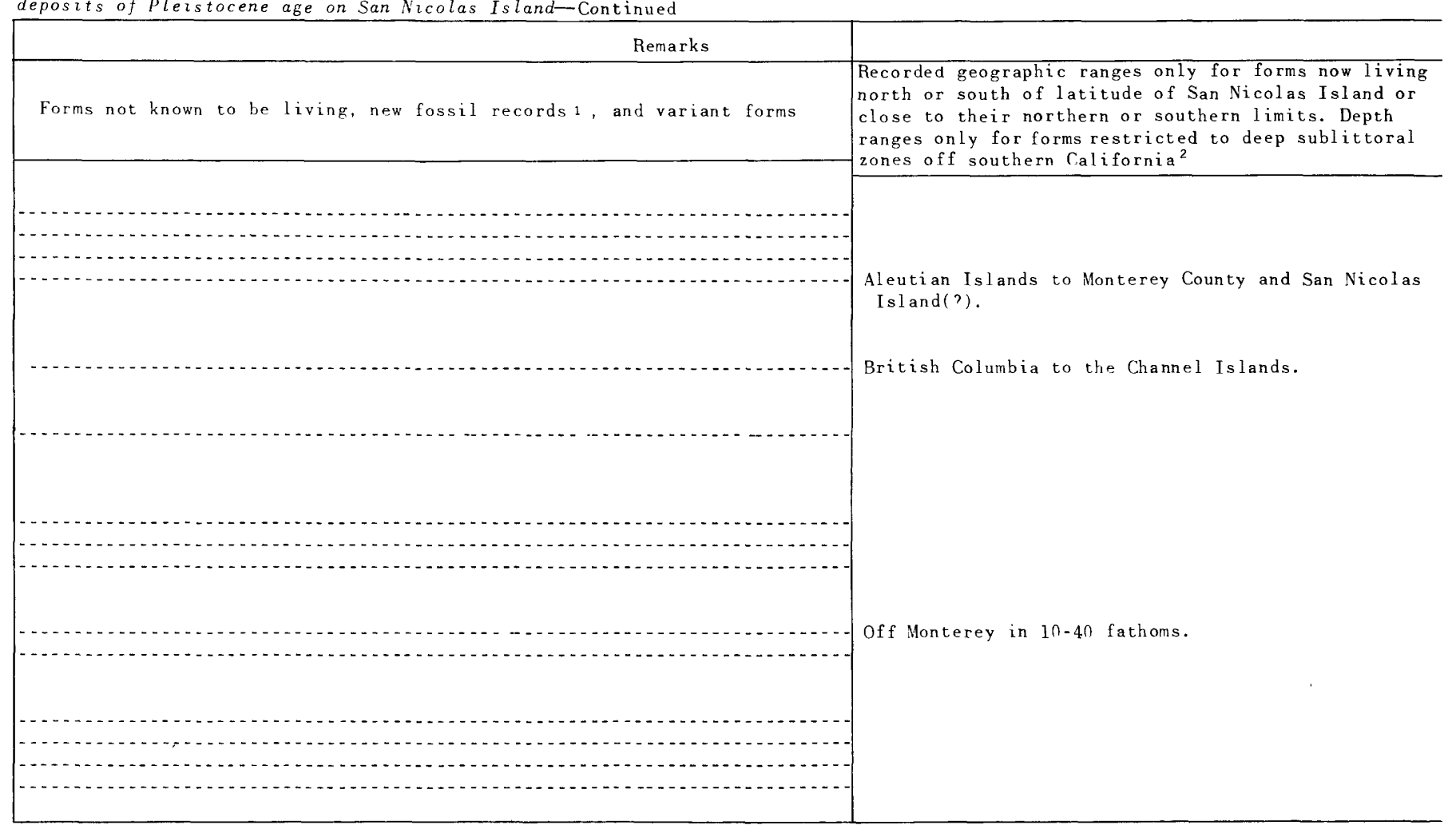

$(1944-46)$, primary reference for geographic and bathymetric distribution of Gastropoda and Pelecypoda; Clark in Natland (1909), geographic and bathymetric ranges of selected Pyramidellidae; Hertlein and Grant (1944b), range data on Brachiopoda; and Woodring and others (1946), range data supplementary to Burch (1944-46). 
TABLE 5.-Mollusks from selected low, intermediate, and high terrace deposits on San Nicolas Island that are known in the living faunas only as extralimital and near limital, or that are not known to be living

[Amphineura, Scaphopoda, and Pyramidellidae not included]

\begin{tabular}{|c|c|c|c|c|c|}
\hline $\begin{array}{l}\text { Locality No., } \\
\text { altitude (feet), } \\
\text { number of forms }\end{array}$ & $\begin{array}{l}\text { Forms now living only } \\
\text { south of the latitude of } \\
\text { San Nicolas Island }\end{array}$ & $\begin{array}{l}\text { Forms now living at or near } \\
\text { their northern limit in the lati- } \\
\text { tude of San Nicolas Island }\end{array}$ & $\begin{array}{l}\text { Forms now living only } \\
\text { north of the latitude of } \\
\text { San Nicolas Island }\end{array}$ & $\begin{array}{l}\text { Forms now li ving at or near } \\
\text { their southern limit in the lati- } \\
\text { tude of San Nicolas Island }\end{array}$ & $\begin{array}{l}\text { Forms not known } \\
\text { to be living }\end{array}$ \\
\hline \multicolumn{6}{|c|}{ Low terraces } \\
\hline $\begin{array}{c}\text { SN-1, SN-12, } \\
\text { SN-13 } \\
45-85 \\
150\end{array}$ & $\begin{array}{l}\text { Gastropoda: } \\
\text { Calyptraea cf. C. mam- } \\
\text { milaris Boderip } \\
\text { Mangelia aff. } M . \\
\text { rhyssa Dall } \\
\text { Terebra (strioterebrum) } \\
\text { aff. T. (S.) lucana } \\
\text { Dall } \\
\text { Pelecypods: } \\
\text { Anadara multicostata } \\
\text { (Sowerby) } \\
\text { Pecten vogdesi Arnold } \\
\text { Bernardina bakeri Dall }\end{array}$ & $\begin{array}{l}\text { Gastropoda: } \\
\text { Tegula cf. T.aureotincta(Forbes) } \\
\text { Arene acuticostata radiata } \\
\text { (Dall) } \\
\text { “Rissoina" cf. “R.” aequis- } \\
\text { culpta (Keep) “ } \\
\text { Amphithalamus inclusus Car- } \\
\text { penter } \\
\text { Crepidula cf. C. exacavata } \\
\text { (Broderip) } \\
\text { Fartulum occidentale Bartsch } \\
\text { Fartulum ef. F. orcutti Dall } \\
\text { Ceratostoma nuttalli (Conrad)? } \\
\text { Jaton cf. J. festious (Hinds) } \\
\text { Morula? cf. M. lugubris (C. B. } \\
\text { Adams) } \\
\text { Pelecypod: } \\
\text { Trigoniocardiabiangulata (Sow- } \\
\text { erby) }\end{array}$ & $\begin{array}{l}\text { Gastropoda: } \\
\text { Acmaea instabilis (Gould) } \\
\text { Tegula brunnea (Philippi) } \\
\text { “Tegula" montereyi (Fischer) } \\
\text { Ocenebra lurida (Midden- } \\
\text { dorff)? } \\
\text { Ocenebra interfossa clathrata } \\
\text { (Dall) }\end{array}$ & $\begin{array}{l}\text { Gastropoda: } \\
\text { Calliostoma ligatum (Gould) } \\
\text { Astraea gibberosa (Dillwyn) } \\
\text { Spirogly phus lituellus (Mörch) } \\
\text { Opalia wroblewskyi chacei } \\
\text { Strong } \\
\text { Ocenebra lurida munda (Dall } \\
\text { in Williamson)? } \\
\text { Boreotrophon stuarti (Smith) } \\
\text { var. } \\
\text { Barbarofusus kobelti (Dall) } \\
\text { Mitra idae Melvill } \\
\text { "Progabbia" cf. "P." cooperi } \\
\text { (Gabb) } \\
\text { Mangelia interfossa Carpenter } \\
\text { Pelecypoda: } \\
\text { Chlamys cf. C. hastatus (Sower- } \\
\text { by) } \\
\text { Irus lamellifer (Conrad) } \\
\text { Gari californica (Conrad) } \\
\text { Parapholas californica (Con- } \\
\text { rad) } \\
\text { Penitella penita (Conrad) }\end{array}$ & $\begin{array}{l}\text { Gastropoda: } \\
\text { Balcis cf. } B . \text { prefalcata } \\
\text { (Bartsch) }\end{array}$ \\
\hline
\end{tabular}

Intermediate terraces

\begin{tabular}{|c|c|c|c|c|c|}
\hline $\begin{array}{c}\mathrm{SN}-10 \\
375 \\
74\end{array}$ & $\begin{array}{l}\text { Pelecypoda: } \\
\text { Bernardina bakeri Dall }\end{array}$ & $\begin{array}{l}\text { Gastropoda: } \\
\text { Amphitahiamus inclusus Car- } \\
\text { penter } \\
\text { Morulag cf. M. lugubris (C. B. } \\
\text { Adams) }\end{array}$ & $\begin{array}{l}\text { Gastropoda: } \\
\text { Pupillaria pupilla (Gould) } \\
\text { Ocenebra interfossa clathrata } \\
\text { (Dall) } \\
\text { Amphissa columbiana Dall }\end{array}$ & $\begin{array}{l}\text { Gastropoda: } \\
\text { Acmaea mitra Eschscholtz } \\
\text { Calliostoma ligatum (Gould)? } \\
\text { Lacuna ef. L. carinata Gould } \\
\text { Spiroglyphus lituellus (Mörch) } \\
\text { Opalia wroblewskyi chacei } \\
\text { Strong } \\
\text { Ocenebra lurida munda (Dall } \\
\text { in Williamson)? } \\
\text { Boreotrophon stuarti (Smith)? } \\
\text { Barbarofusus kobelti (Dall)? } \\
\text { Mangelia interfossa Carpenter } \\
\text { Pelecypoda: } \\
\text { Chlamys hastatus (Sowerby)? } \\
\text { Miodontiscus prolongatus Car- } \\
\text { penter } \\
\text { Tellina salmonea (Carpenter) } \\
\text { Clinocardium nuttallii (Con- } \\
\text { rad)? }\end{array}$ & $\begin{array}{l}\text { Gastropoda: } \\
\text { Calicantharus fortis } \\
\text { (Carpenter) } \\
\text { Balcis cf. B. arnoldi } \\
\text { (Bartsch) } \\
\text { Pelecypod: } \\
\text { Arca sisquocensis Rein- } \\
\text { hart? }\end{array}$ \\
\hline $\begin{array}{c}\text { SN-11 } \\
590-595 \\
70\end{array}$ & $\begin{array}{l}\text { Gastropoda: } \\
\text { Acanthina cf. A. lugu- } \\
\quad \text { bris (Sowerby) }\end{array}$ & $\begin{array}{l}\text { Gastropoda: } \\
\text { Tegula gallina multifilosa } \\
\text { (Stearns) } \\
\text { "Rissoina" aequisculpta } \\
\text { (Keep) } \\
\text { Amphithalamus inclusus Car- } \\
\text { penter } \\
\text { Fartulum cf. F. orcutti Dall } \\
\text { Macron cf. M. lividus A.Adams }\end{array}$ & $\begin{array}{l}\text { Gastropoda: } \\
\text { Tegula brunnea (Philippi) }\end{array}$ & $\begin{array}{l}\text { Gastropoda: } \\
\text { Acmaea mitra Eschscholtz } \\
\text { Puncturella cooperi Carpenter? } \\
\text { Astraea cf. A. gibberosa (Dill- } \\
\text { wynn) } \\
\text { Spiroglyphus lituellus (Mörch) } \\
\text { Mitra idae Melvill } \\
\text { Pelecypoda: } \\
\text { Modiolus of. M. fornicatus } \\
\text { (Carpenter) } \\
\text { Irus cf. I. lamellifer (Conrad) }\end{array}$ & $\begin{array}{l}\text { Gastropoda: } \\
\text { Calicantharus fortis } \\
\text { (Carpenter) }\end{array}$ \\
\hline \multicolumn{6}{|c|}{ High terraces } \\
\hline $\begin{array}{c}\text { SN-2, SN-3 } \\
730-735 \\
140\end{array}$ & $\begin{array}{l}\text { Gastropoda: } \\
\text { Alvania cf. } A . \text { lirata } \\
\text { (Carpenter) } \\
\text { Elachisina grippi Dall } \\
\text { Mangelia aff. } M \text {. rhyssa } \\
\text { Dall }\end{array}$ & $\begin{array}{l}\text { Gastropoda: } \\
\text { Arene acuticostata radiata } \\
\text { (Dall) } \\
\text { Rissoina ef. } R \text {. coronadoensis } \\
\text { Bartsch } \\
\text { Amphithalamus inclusus Car- } \\
\text { penter } \\
\text { Crepidula cf. C. excavata (Brod- } \\
\text { erip) } \\
\text { Fartulum occidentale Bartsch }\end{array}$ & $\begin{array}{l}\text { Gastropoda: } \\
\text { Haliotis kamtschatkana Jonas } \\
\text { Tegula brunnea (Philippi) } \\
\text { Rissoina cf. R. hannai Smith } \\
\text { and Gordon } \\
\text { Alvania aff. A. dinora Bartsch } \\
\text { Velutina aff. V. laevigata } \\
\text { (Linnaeus) } \\
\text { Ceratostoma foliatum (Gmelin) } \\
\text { Ocenebra cf. O. lurida (Mid- } \\
\text { dendorff) } \\
\text { Ocenebra cf. O. interfossa clath- } \\
\text { rata (Dall) } \\
\text { "Searlesia" dira (Reeve) } \\
\text { Barbarofusus harfordi (Stearns) } \\
\text { Pelecypoda: } \\
\text { Chlamys hastatus hericius } \\
\text { (Gould) }\end{array}$ & $\begin{array}{l}\text { Gastropoda: } \\
\text { Acmaea mitra Eschscholtz } \\
\text { Puncturella cf. P. cooperi Car- } \\
\text { penter } \\
\text { Tegula brunnea fluctuosa } \\
\text { (Dall) } \\
\text { Calliostoma cf. C. ligatum } \\
\text { (Gould) } \\
\text { Astraea gibberosa (Dillwyn) } \\
\text { Lacuna ef. L. carinata Gould } \\
\text { Spiroglyphus lituellus (Mörch) } \\
\text { Barbarofusus kobelti (Dall) } \\
\text { Mitra idae Melvill } \\
\text { Pelecypoda: } \\
\text { Modiolus fornicatus (Carpen- } \\
\text { ter) } \\
\text { Chlamys hastatus (Sowerby) } \\
\text { Irus lamellifer (Conrad) } \\
\text { Clinocardium nuttallii (Con- } \\
\text { rad)? } \\
\text { Parapholas californica (Con- } \\
\text { rad) } \\
\text { Penitella penita (Conrad) }\end{array}$ & $\begin{array}{l}\text { Gastropoda: } \\
\text { Crepidula princeps } \\
\text { Conrad, large form } \\
\text { Calicantharus fortis } \\
\text { Carpenter } \\
\text { Pelecypoda: } \\
\text { Arca sisquocensis Rein- } \\
\text { hart } \\
\text { Humilaria perlaminosa } \\
\text { (Conrad) }\end{array}$ \\
\hline
\end{tabular}


CAUSES AND EFFECTS OF SURFACE WATER TEMPERATURE VARIATION OFF SOUTHERN CALIFORNIA AND NORTHWESTERN BAJA CALIFORNIA

Causes other than the advance and retreat of polar icecaps and changes in worldwide oceanic circulation may have brought about temperature changes of the California coastal surface waters during various terrace-cutting episodes. The prevailing westerly winds have a pronounced seasonal effect on the surface water temperatures along the southern California and Baja California coasts at the present time (Sverdrup, Johnson, and Fleming, 1942, p. 724-725; Kuenen, 1950, p. $31)$. Changes in the direction or force of the prevailing winds, even for a short period, may result in a temperature differential of several degrees in the surface water. Extraordinarily warm surface water temperatures recorded off southern California in the period 1850-1870, in 1926, 1931, 1941, 1947 (Hubbs, 1948 , p. $469-474$ ), and again in 1957 and 1958 , presumably were due to abnormalities in atmospheric circulation with a resulting decrease in intensity of the prevailing westerly winds (Namais, 1959). During the summer of 1957 surface water temperatures averaged 2 to 3 degrees Fahrenheit higher than usual at coastal gaging stations and averaged slightly more than $5^{\circ}$ above normal in some areas 150 miles off the coast. In Santa Monica Bay, the water temperature was $5.3^{\circ}$ F. above the mean during February 1958. Cooler-thannormal surface water temperatures would be expected to result from increased intensity of the prevailing winds. Another possible cause of cold upwelling is that the southeast-flowing California Current may produce a drag effect on the surface water above Santa Rosa-Cortes Ridge to force this water seaward, and the replacement of the surface water, in part, by subsurface water from the deep basins may result in cooler surface water temperatures (Orr, Emery, and Grady, 1958, p. 929).

Deep indentations in the coastline in the form of shallow embayments warmed by solar radiation adjacent to open coast waters cooled by upwelling create habitats and depositional environments that might easily result in an anomalous association of dead shells after a short distance of transport. There is a striking change in surface water temperature from the northeast to the southwest side of Punta Banda, which forms the southern extremity of Bahia Todos Santos in Baja California. Here the seasonal temperature differential from the protected shallow bay to the windy outer coast may be as high as $21^{\circ} \mathrm{F}$. (Walton, 1955 , p. 966 ).

High coastal mountain ranges produce a dampening effect on the prevailing winds along parts of the coast of southern California with the result that near-shore surface waters in some areas remain relatively warm. The Santa Ynez Mountains along the Santa Barbara coast and the Santa Monica Mountains to the southeast tend to deflect prevailing winds. During part of late Pleistocene time the Santa Monica Mountains presumably extended west approximately 85 miles and included the area that is now occupied by the northwestern group of Channel Islands. This topographic barrier undoubtedly diverted coastal currents and resulted in a local pronounced temperature differential (Grant and Gale, 1931, p. 39, 64; Woodring and others, 1946, p. 102). However, this peninsula may have existed only during low eustatic stands of sea level. Although large-scale topographic barriers to wind and oceanic currents and expansive coastal indentations almost certainly affected water temperature locally along the mainland coast, these features probably did not significantly alter surface conditions around ancestral San Nicolas Island except at the time of the cutting of the lower submerged terraces.

The composition and distribution of the Pleistocene and Recent floral and faunal assemblages along the coast of southern California and northwestern Baja California apparently is governed to a large degree by surface water temperature (Dawson, 1951, p. 3958; Valentine, 1955, p. 466-468; Emerson, 1956a, p. $334-335)$. From the preceding discussion it can be ascertained that both cool and warm surface water probably existed in adjacent areas and that local cold upwellings or protected areas of warm surface water may have caused faunal and floral gaps or displacements and the resultant seemingly anomalous mixing of molluscan faunas in places along the coast of California and Baja California in Pleistocene time. Rapid distribution of hardy forms of mollusk larvae from the north by a cold ancestral California Current and from the south by warm countercurrents or warm surface water resulting from diminished prevailing winds could account for an influx of both cool and warm water forms into close proximity in California coastal areas. Protected shallow bays and areas of local intense upwelling would then provide suitable temperatures for the existence of migrant cool-water and warm-water adult forms, for at least one, or at most a few, generations.

\section{INADEQUACIES OF PALEOECOLOGIC COMPARISONS OF TERRACE FAUNAS}

The chief difficulty in making paleoecologic inferences from the composition of the terrace faunas at San Nicolas Island is the lack of complete faunal and ecologic data concerning the Recent forms that now live around the island. The insufficient collected living material, even from the intertidal zone, results 
in a poor correlation with the mainland coast, a deficiency which, in turn, hampers comparisons with the Pleistocene faunas both on the island and along the mainland coast.

The dominant rock-cliff and tide-pool facies of the ancient outer coast indicated by constituents in the fossil collections is not particularly significant when employed to infer isothermal shifts in Pleistocene time because most of the abundant forms found in this facies are geographically widely dispersed in both the fossil and living faunas. Fossil assemblages from restricted environment or mixed habitats are more likely to yield mollusks that reflect changes in surface-water temperature.

The recorded geographic and bathymetric ranges of living species are far from complete, especially along the coast of northwestern Baja California. Some early reports of geographic ranges in southern California are undoubtedly based on detrital fossil shells reworked into Recent sediments. As a result erroneous conclusions are likely to be derived from strict adherence to these data. A further complication of the distributional pattern results from apparent gaps within the geographic ranges that presumably are caused by local areas of intense upwelling of cold water such as that found off Punta Santo Tomas, Baja California (Emerson, 1956b, p. 394-395), or by embayments of abnormally warm water such as those that occur in Scammon Lagoon and Magdalena Bay in Baja California. There is little doubt that faunal breaks of the same nature or dislocations in molluscan distribution occurred in Pleistocene time along the California coast. Faunal discontinuities and extra-limital occurrences are reflected in deposits of Pleistocene age at Palos Verdes Hills (Woodring and others, 1946, p. 87-89), Newport Lagoon (Bruff, 1946, p. 222), San Diego (Hertlein and Grant, 1944, p. 71-72), and at (several localities in northwestern Baja California (Addicott and Emerson, 1959, p. 21; Emerson, 1956a, p. 325; Valentine, 1955 , p. 465,1957 , p. 302). Large shallow embayments of warm water probably did not exist along the coast of San Nicolas Island during late Pleistocene time, but extended periods of inactive upwelling may have produced the warm surface water temperatures necessary to support the growth of southern molluscan forms.

Another factor to be considered when drawing paleoecologic conclusions, although it may not be significant when applied to late Pleistocene faunas, is the possibility that the physiology or status of evolution of certain organisms may have enabled them to tolerate more diverse environmental conditions in the past.
The chemical composition and the nutrient content of the sea water also may have affected the components within localized molluscan faunas in Pleistocene time just as these factors control assemblage constituents at the present time.

Furthermore, anomalous or mixed assemblages usually are present in large accumulations of dead shells resulting from the transport of different environment indicators into the same deposit or from the reworking of individuals from older deposits into younger sediments. Also, the common practice of selective collecting rather than collecting bulk assemblages may lead to errors in paleoecologic interpretation.

\section{AGE AND FAUNAL CORRELATION}

The age of the entire sequence of terrace-deposit faunas on San Nicolas Island is presumed to be Pleistocene and possibly is restricted to the last third of the epoch. No species considered to be restricted to strata of Pliocene age were found on the older high terraces, and a large percentage of the molluscan forms found in each of the terrace deposits is now living off the California coast.

Species considered extinct were not collected on the low terraces, and only 3 percent of the species found on the high platforms are not known to be living. This low percentage of presumably extinct mollusks is generally considered to be sufficient evidence for dating the terrace assemblages as Pleistocene, but it is unlikely that early Pleistocene terrace deposits can be differentiated from late Pleistocene terrace deposits on a faunal basis (Woodring and others, 1946, p. 99). Locality $\mathrm{SN}-3$ has yielded forms usually considered to be early Pleistocene guides, or forms that rarely are found in late Pleistocene terrace deposits (large form of Crepidula princeps, Calicantharus fortis, Humilaria perlaminosa, and Arca sisquocensis). The presence of these species is attributed to the survival at San Nicolas Island of a relict fauna not known to occur in the higher terrace deposits along the mainland coast rather than to the deposition of strata equivalent to the early Pleistocene Santa Barbara formation, Lomita marl, Timms Point silt, or San Pedro sand.

The apparent lack of tilting even on the highest terrace platforms on San Nicolas Island suggests a late Pleistocene age, although the areal extent of the higher platforms is not sufficient to demonstrate slight regional tilting. Elsewhere in coastal southern California fossiliferous sedimentary rocks designated as early Ploistocene in age are folded and faulted. Marine sediments assignable to the middle Pleistocene are 
not certainly known in southern California but may be present in the central parts of the Los Angeles and Ventura Basins, where deposition was continuous (Woodring, 1952, p. 402). Late Pleistocene terrace deposits are locally deformed along the margins of the Los Angeles and Ventura Basins. Because no truncated sedimentary rocks of definite early Pleistocene or Pliocene age exist on the island, stratigraphic evidence for the age of the terrace deposits is lacking. The absence of Pliocene guide fossils and the low percentage of extinct forms in the terrace deposits on the island are the only available paleontologic evidence that the faunas are Pleistocene in age.

The upper age limit for cutting of the lowest emergent terraces along the coast of California has been fairly well established at greater than 30,000 years. Selected samples taken at several low terrace localities from Santa Cruz to San Diego, including the marine strata and the associated nonmarine cover, have provided radiocarbon dates that range from greater than 30,000 years to greater than 39,000 years (Kulp and others, 1952; Rubin and Suess, 1955; Rubin and Suess, 1956 ; Bradley, 1956; Broecker and Kulp, 1957 ; Carter, 1957 , p. $6-7$; Hoskins) ${ }^{29}$ Radiocarbon dates on calcareous red algae cored from the shelf edge below the supposed deepest submerged terrace off the Palos Verdes Hills at water depths of 334 to 387 feet showed a range in age from 17,000 to 24,500 years (Emery, 1958 , p. 56), suggesting that the lowest emergent terraces are older than the submerged terraces off the California coast. Presumably the lowest well-developed 100-foot terrace on San Nicolas Island is older than 30,000 years, if a physiographic correlation is made from the mainland coast to the island, and if the warm-water constituents of the late Pleistocene Palos Verdes sand and its equivalents correlate with the few warm-water forms from SN-1, SN-12, and SN-13 (see table 5).

Definite faunal correlations, terrace by terrace, with other nearby islands and the mainland coast cannot be made with confidence because of the lack of molluscan guide species restricted to any single terrace level, the great variety in environments represented by the well-known terrace assemblages, and the scarcity of large fossil assemblages on the higher terraces of the mainland. The supposed warm-water elements found in the low terraces on San Nicolas Island strongly suggest a faunal correlation with the fossil assemblages of warm-water aspect that are present on the four lower emergent terraces of the Palos Verdes Hills (Woodring and others, 1946, p. 95) and on the

\footnotetext{
${ }^{29}$ See footnote 13, p. 10.
}

lowest emergent terrace elsewhere in southern California.

Large molluscan assemblages collected by Valentine (1958) from the lowest emergent terrace at Cayucos, which are referred to a central California late Pleistocene faunal province, are strikingly similar to the San Nicolas Island terrace assemblages. Other large faunas composed primarily of the rock-cliff and tide-pool facies that resemble those from San Nicolas Island are known from several localities on the lowest emergent terrace in southern California and Baja California; collections numbering more than 90 species of mollusks are known from the following places: Laguna Beach-Dana Point area (more than 275 forms, Vedder and others, 1957, [localities only]), Point Loma (97 forms, Webb, 1947), Punta Descanso area (230 forms, Valentine, 1957), Punta China (96 forms, Emerson, 1956), and Punta Cabras area (99 forms, Addicott and Emerson, 1959) (fig. 18).$^{30}$ Most of the other large well-known assemblages (more than 100 forms) from the well-developed low terrace in southern California represent mixed ecologic facies of bay and estuarine facies such as those reported from Potrero Canyon near Santa Monica (Woodring in Hoots, 1931, p. 121-122; Valentine, 1956), Playa del Rey (Willett, 1937a), Palos Verdes Hills (Woodring and others, 1946, p. 95-96), Newport Beach area (Bruff, 1946), and San Diego area (Arnold, 1903, p. 58-64; Hertlein and Grant, 1944a, p. 66-72). Exceptionally large mixed faunas also occur on the next highest well-developed terrace at several localities along the coast; the best known are at Palos Verdes Hills (Woodring and others, 1946, p. 93-95) and perhaps at Capistrano Beach (Willett, 1937b).

There is no justification for direct faunal correlations between the high terraces on San Nicolas Island and those found elsewhere in southern California and northwestern Baja California even though many of the individual platforms may have been cut contemporaneously in different areas. Only meager fossil assemblages have been obtained from terrace deposits above 400 feet along the California coast with the notable exceptions of the Palos Verdes Hills, where several collections have yielded faunas of the rockcliff and tide-pool facies up to an altitude of 1,215 feet (Woodring and others, 1946, p. 93-95), and in the Ventura area, where a mixed ecologic facies is represented at altitudes of 500 and 700 feet (Putnam, 1942, p. 699-700). Many of the species from these localities are the same as those found in the terrace deposits above 400 feet on San Nicolas Island.

\footnotetext{
${ }^{30}$ These records are compiled from reports published before November 1959.
} 


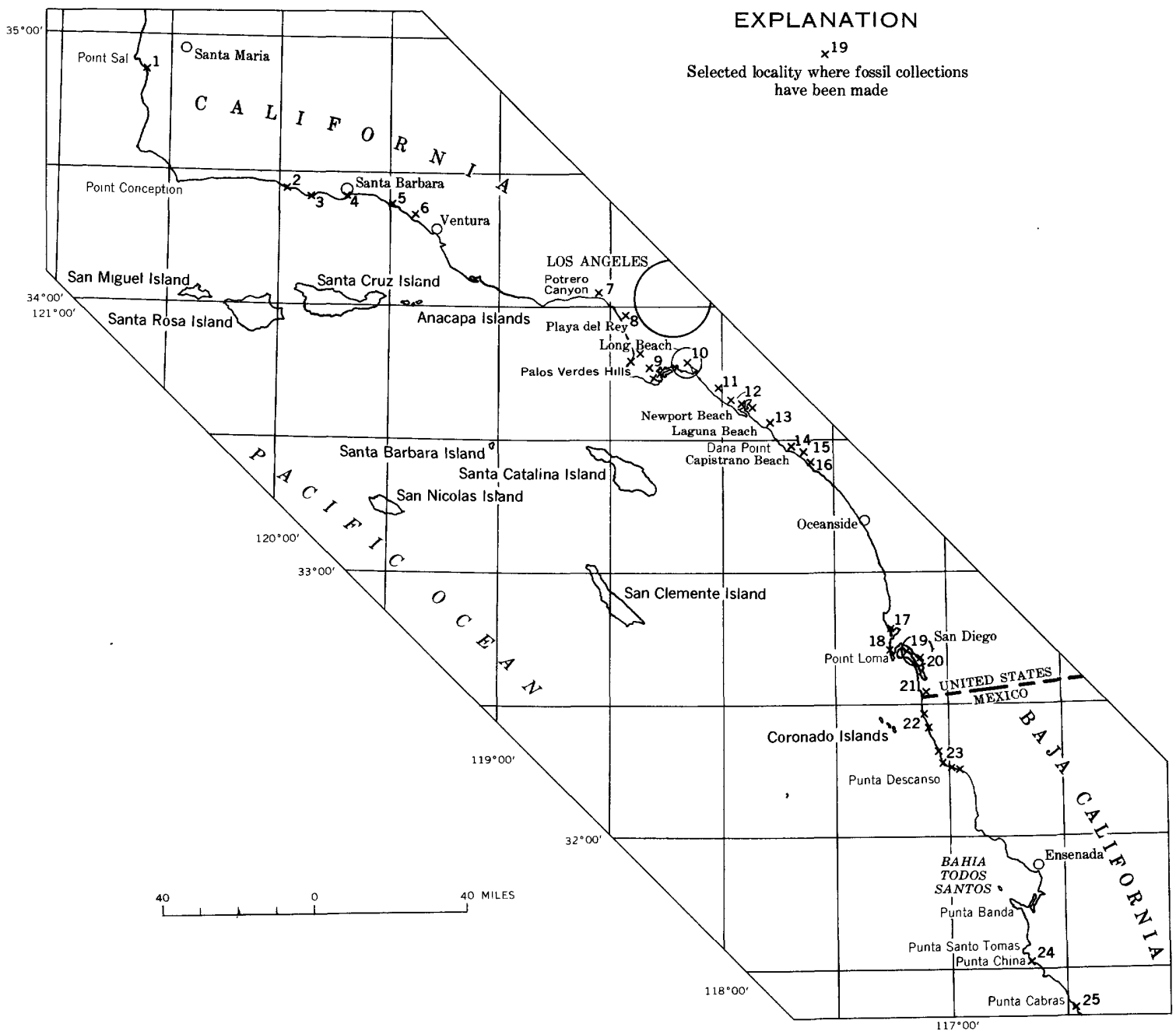

Figure 18.-Map showing distribution of selected fossil localities in terrace deposits of southern California and northwestern Baja California (Santa Maria to Punta Cabras) that have yielded 40 or more molluscan forms. Only a few localities in the Ventura area and in the Palos Verdes Hills contain fossils on wave-cut platforms that are higher than the lowest emergent terrace.

1. Santa Maria area, loc. 263 (Woodring and Bramlette, 1950, p. 53-54)

2. Loc. H56-64 (Hoskins, 1 p. 59)

3. Goleta (Oldroyd and Grant, 1931; Hoskins, ${ }^{1}$ p. 58-59)

4. Santa Barbara, loc. H56-21 (Hoskins, 1 p. 57)

5. Carpinteria (Grant and Strong, 1934)

6. Ventura area, loc. 1 (Putnam, 1942, p. 699-700)

7. Potrero Canyon (Woodring in Hoots, 1931, p. 121-122; Valentine, 1956)

8. Playa del Rey (Willett, 1937a)

9. Palos Verdes Hills area (Arnold, 1903, p. 22-47; Woodring and others, 1946 p. 54-106; Hoskins, ${ }^{1}$ p. 53-54)

10. Signal Hill area (DeLong, 1941)

11. Huntington Beach (Hoskins, 1 p. 49-50)

12. Newport Beach area (Bruff, 1946; Hoskins, 1 p. 46-48)

13. Laguna Beach area (Vedder and others, 1957 [localities only]; Hoskins, ${ }^{1}$ p. 45)

14. Dana Point (Vedder and others, 1957 [locality only])

\section{KITCHEN MIDDENS}

The term "kitchen midden," an anglicized Danish word, is applied to any occupational debris that demarks areas of prehistoric settlement. Extensive refuse dumps and habitation sites of the former Indian population on San Nicolas Island are concentrated in the dune areas on the western part of the island near the coast but also occur sporadically on the upper terrace
15. Capistrano Beach (Willett, 1937b)

16. San Clemente (Vedder and others, 1957 [localities only]; Hoskins, ${ }^{1}$ p. 43)

17. Pacific Beach (Arnold, 1903, p. 58, 60-64)

18. Point Loma (Webb, 1937)

19. Spanish Bight (Arnold, 1903 , p. 59, 60-64; Hertlein and Grant, 1944, p. 67-70)

20. Indian Point (Arnold, 1903, p. 59, 60-64 [foot of 26th street])

21. Border locality (Emerson and Addicott, 1953)

22. UCLA loc. 3161 and 3160 (Valentine, 1957)

.23. Punta Descanso area (Valentine, 1957)

24. Punta China area (Emerson, 1956a)

25. Punta Cabras area (Addicott and Emerson, 1959)

1 Hoskins, C. W., 1957, Paleoecology and correlation of the lowest emergent California marine terrace, from San Clemente to Halfmoon Bay: Stanford Univ., unpublished $\mathrm{Ph}$. D. thesis.

platforms near the center of the island. The only places that appear to be entirely free of discarded shell material are the higher marine terrace levels at the east end of the island and the steeper parts of the south side some distance from the shore.

Description of the middens and their content is included in this report not only as evidence for the length of prehistoric habitation of San Nicolas Island 
but also as a means of inferring climatic conditions and surface sea-water temperature during early Recent time.

Near the west coast of the island several of the larger middens cover dunes that measure from 1,200 to 1,600 feet in length and from 300 to 500 feet in width. The highest of the midden-covered dunes is 50 to 70 feet above the surrounding areas. Few of the concentrations of shells marking the occupational levels are more than 1 or 2 feet thick on the tops of the dunes, but some shell accumulations on the margins attain a thickness of 5 feet. Ordinarily the eroded sides of the dunes are strewn with midden debris derived by wind deflation from the relatively thin occupational levels, giving the false impression of a thick sequence of levels. However, the deepest observed shell layers are but 5 feet below the present dune surface.

Most of the shell heaps in the high central portion of the island and along the central south coast are much smaller than the large mounds on the west end of the island.

A map showing the location of 68 archeological sites was compiled by Meighan and Eberhart (1953, p. 110 , fig. 33), but these authors do not include several fairly extensive middens on the south side of the island in the areas northwest and southwest of Seal Beach. A few additional sites are present on the upper surface of the island and near the coast between Dutch Harbor and Jehemy Beach. The same authors postulate an aboriginal population of between 600 and 1,200 individuals at the time of maximum development just prior to European contact (Meighan and Eberhart, 1953, p. 119, p. 123).

The most abundant constituent in the kitchen middens is mollusk shells, followed in diminishing order by rock fragments, mammal, fish, and bird bones, and a variety of artifacts. The lists of mollusk (see table 6) and associated marine invertebrate species observed in the shell mounds indicates the wide variety of forms used by the early islanders for food, ornaments, and artifacts. Several species that probably do not now live on San Nicolas Island suggest that some were imported by the natives from nearby coastal areas (for example, Trachycardium elatum, Pachydesma crassatelloides) or are locally extinct (for example, "Cryptochiton" stelleri). In addition to the mollusks, the bones of fish, birds, sea lions, seals, sea otters, whales, porpoises, dogs, and foxes are present in varying abundance. A diversified assemblage of artifacts is briefly described by Meighan and Eberhart (195), p. 111-112, p. 119-123). The list of artifacts includes tools made of ground stone, chipped stone, shell, and bone; ornaments and burial offerings of shell, bone, and stone; textiles and cordage; and "foreign" artifacts such as pottery and worked stone of exotic origin.

TaBle 6.-List of invertebrates observed in kitchen middens [A, abundant; C, common: $\mathrm{U}$, uncommon; $\mathrm{R}$, rare]

Gastropoda:

Acmaea limatula Carpenter.

Acmaea mitra Eschscholtz

Lottia gigantea (Sowerby)

Acmaea pelta nacelloides Dall ${ }^{1}$

Haliotis corrugato Gray ${ }^{1}$

Haliotis cracherodii Leach.

(

Megathura renulata (Sowerby)

Diodora aspera (Eschscholtz) ${ }^{1}$

Norrisia norrisi (Sowerby) _._.

Tegula brunnea (Philippi) _._.

Tegula funebralis (Adams) _.

"Tegula" montereyi (Fischer) _................. R

Astraea gibberosa (Dillwyn) ${ }^{1}$

Astraea undosa (Wood)

Lunatia lewisii (Gould)

Zonaria spadicea (Swainson) _.

Pusula californiana (Gray

Pusula solandri (Sowerby) ${ }^{1}$

Bursa californica Hinds_...

Ocenebra circumtexta (Stearns) ${ }^{1}$

Acanthina spirata punctulata (Sowerby) ${ }^{1}$

Barbarofusus arnoldi (Cossmann) _. . . . . . . . . .

Mitra idae Melvill.

Erato vitellina Hinds 1

Olivella baetica Marrat in Sowerby ${ }^{1}$

Olivella biplicata (Sowerby)

"Progabbia" cooperi (Gabb)

Trimusculus reticulatus (Sowerby) ${ }^{1}$

Land snails, unidentified

Pelecypoda:

Mytilus californianus Conrad.

Septifer bifurcatus (Carpenter)

Aequipecten ef. A. circularis (Sowerby)

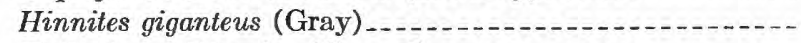

Epilucina californica (Conrad)

Irus lamellifer (Conrad)1

Pachydesma crassatelloides (Conrad) [Tivela stultorum

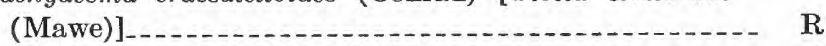

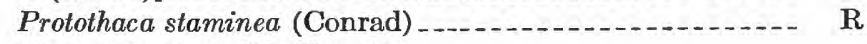

Ventricolaria fordii (Yates) ${ }^{1}$

Trachycarium quadragenarium (Conrad) _.......... $\quad \mathbf{R}$

Trigoniocardia biangulata (Sowerby) ${ }^{1}$

Laevicardium elatum (Sowerby)

Amphineura:

Ischnochiton conspicuus Pilsbry ${ }^{1}$

"Cryptochiton" stelleri (Middendorff) _...............

Small chitons, unidentified

Echinoidea:

Strongylocentrotus franciscanus (Stimpson) -..........-

Strongylocentrotus purpuratus (A. Agassiz)

Cirripedia:

Coronula? ef. C. diadema (Linnaeus)

${ }^{1}$ Reported by H. N. Lowe (1903), but not found by the authors. 
Observations of a number of the kitchen middens suggest the presence of several successive occupational levels that could be differentiated by a thorough archeologic investigation. A hasty survey revealed two cultural levels connected by transitional sites. The earliest stratigraphic levels seem to be limited to the northwest and west parts of the island from the coast to the upland surface in the vicinity of hill 616 . These early levels lie a few feet below the extensive surface midden deposits and are characterized by an abundance of large red abalone shells (Haliotis rufescens), localized heaps of large sea urchins (Strongylocentrotus franciscanus), and small piles of large turban shells (Astraea undosa). Plates from the giant chiton ("Cryptochiton" stelleri) commonly are concentrated in small mounds throughout the older sites. Black abalone shells (Haliotis cracherodii) seldom are present. Many of the lower occupational sites are in dune sand partly cemented by caliche and others contain well-cemented calcareous root casts but none occur in the reddish-brown deposits. Artifacts are rare and often seem to be entirely lacking in red abalone horizons, suggesting that occupation of the sites was seasonal.

A number of transitional cultural levels may exist on San Nicolas Island, but the lack of a complete stratigraphic sequence of levels within one dune or even within a restricted area and the usual occurrence of but one occupation site within a single dune makes it difficult to demonstrate the presence of more than one transitional culture on the basis of a hasty examin-

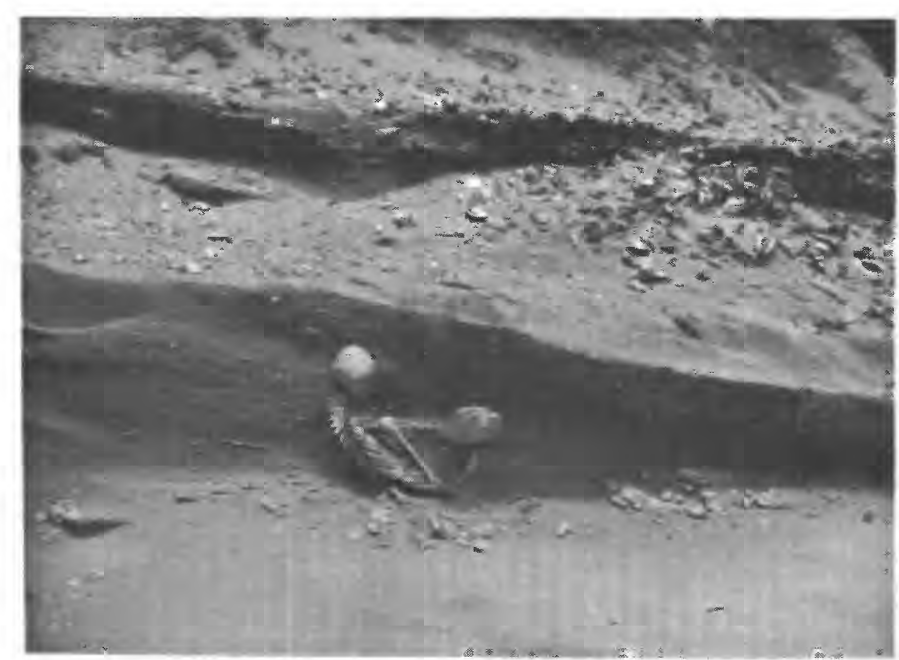

Figdre 19.-Kitchen-midden deposits overlying a flexed human burial exposed in a wind-scoured trough near Seal Beach. The partly cemented old dune in which the midden and burial occur is overlain by an active dune in the upper background. This midden represents a time of aboriginal occupation when large mussels were the predominant food. ation. Several of the large middens midway between Vizcaino Point and Thousand Springs exhibit at least three definite shell beds that may be interpreted as transitional culture levels. These transitional sites ordinarily contain mixed small red abalone and large black abalone shells, a great abundance of large mussel shells (Mytilus californianus), and some land snail shells, but they yield relatively few artifacts when compared to the later occupational sites (fig. 19). Partly decomposed fish bones are abundant but mammal bones are rare. No evidence of cementation or the presence of calcareous root casts was observed.

The uppermost midden levels that occur on the surface of many dunes generally contain an abundance of small black abalone shells, scattered small mussel shells, assorted small turbans and limpets, and numerous land-snail shells. Artifacts are relatively common on the surface and usually in good condition. The most striking feature of the upper levels is the black sootlike composition of the sand matrix and the slightly greasy texture of the midden material. The refuse heaps of the later sites are uncemented and contain many well-preserved mammal, bird, and fish bones.

Relatively long aboriginal occupation of San Nicolas Island is indicated by the definite change in the predominating invertebrate types used for food from the time of early habitation to 1836 , when the last remaining group of Indians was removed to the mainland. The dwindling of the molluscan food supply and the gradual disappearance of the large forms probably was caused by excessive exploitation of the marine life by the Indians, but not from the warming of the surface waters and the resulting local extinction of the red abalone as implied by Carter $(1957$, p. 132). The common presence of the south-ranging, predominantly subtidal large turban (Astraea undosa) in the same deposits as the large sea urchins (Strongylocentrotus franciscanus), the red abalone (Haliotis mufuscens), and giant chiton plates (Cryptochiton" stelleri) seems to disprove the implication that surface waters colder than at present persisted around the island well after the world-wide post-Wisconsin temperature rise. Furthermore, the red abalone and the large sea urchin now live in a few areas of shallow subtidal water (less than 3 fathoms) as well as in deeper water around San Nicolas Island. Thus, it seems likely that the early aborigines obtained part of their food supply by diving in shallow water for the above-noted forms, which are most commonly found below the intertidal zone.

The transitional occupational levels, which seem to have existed for a long period of time, show a decrease in preferable seafood types. The red abalone shells are usually small and the medium-size black abalone shells 
are more abundant. One of the chief constituents of the transitional levels is the mussel, but the large turbans and giant sea urchins are uncommon.

Apparently the available molluscan food supply diminished rapidly during the later stages of the transitional occupation. The youngest archeological sites contain numerous land-snail shells, but the red abalone shells are almost entirely replaced by small black abalone shells. Mussel shells are smaller and less abundant, and small heaps containing hundreds of tegulas (Tegula funebralis, Tegula brunnea) with broken apices together with numerous limpets (Lottia gigantea) occur in the uppermost occupational debris. This assemblage presumably indicates that the available supply of large mollusks had been almost completely exhausted by the time the fow remaining inhabitants were removed from the island, or that the art of diving for the large subtidal forms had been lost. The depletion of the easily acquired food supply may partly account for the fact that only a few Indians remained on the island at the time the mission authorities sent a schooner to take the natives to the mainland.

Further careful analysis of the molluscan and perhaps the mammalian content of the kitchen middens may result in a better and more complete zonation of the deposits than has been done by earlier workers.

The antiquity of the cultural levels on San Nicolas Island is highly conjectural. ${ }^{31}$ Meighan and Eberhart (1953, p. 115-118) suggest that the occupation of the island was relatively recent as compared to that of the mainland; that is, less than 2,000 years and most of it after A.D. 1000. Orr (1951, p. 224) implies that the habitation of San Nicolas Island extended much further into the past. A red abalone shell contained in a mass human burial found by Orr at Santa Cruz Island was dated at 7.050 \pm 300 years by Broecker and Kulp $(1957$, p. 1328$)$. A comparable age may apply to the oldest red abalone mounds on San Nicolas Island (Carter, 1957, p. 132).

\section{ECONOMIC GEOLOGY}

\section{PETROLEUM POSSIBILITIES}

The surface geology on San Nicolas Island indicates the presence of subsurface structures suitable for small accumulations of oil and gas. However, the complete lack of information concerning the thickness and lithology of the concealed rocks prevents adequate

\footnotetext{
s1 A radiocarbon date of $5,070+250$ B.P was obtained in 1961 from red abalone shells collected from a midden 1,675 feet $N$. $60^{\circ} \mathrm{E}$. from BM-616 (Meyer Rubin, written communication, 1961, sample W-981). These shells were taken from the middle of a layer 8 to 18 inches thick and 4 to $4 \frac{1 / 2}{2}$ feet below the surface of the youngest midden layer. Although this site represents the oldest cultural type on San Nicolas Island. similar middens may be as old as the mass burial on Santa Cruz Island.
}

evaluation of their petroleum potential. Until additional geophysical and stratigraphic core-hole data are available, the presence or absence of source rocks and reservoir rocks in the subsurface section of the island will remain conjectural.

Oil and tar seeps were not observed on the island, but small irregular masses of tar are concentrated on the rocks and beaches along the west and northwest shores. Possibly the tar emanates from unknown submarine seeps adjacent to the west end of the island, but it is more probable that the tar drifts ashore from known submarine seeps off the west end of San Miguel Island.

Even if a thick section of sedimentary rocks of Late Cretaceous and Eocene age is present beneath San Nicolas Island, is is not likely that such a sequence would produce commercial quantities of oil, for rocks of the same age yield only a small percentage of the petroleum produced in California. Two wells drilled by Richfield Oil Corporation on Santa Cruz Island in 1955 penetrated Upper Cretaceous sedimentary rocks that might be assumed to be similar to the unknown section beneath San Nicolas Island. Neither well reported showings of oil or gas. The nearest known accumulations of petroleum in rocks of Eocene age are in the Ventura basin, where only a very small amount of oil is produced from Eocene rocks in a few fields. The closest commercial production of oil from Upper Cretaceous rocks is in the San Joaquin Valley approximately 200 miles north of San Nicolas Island.

\section{WATER RESOURCES}

Three shallow wells (60 to 72 feet deep) in the upper drainage basin of Tule Creek together with catchment basins beneath a line of springs in the deep canyon cut by Tule Creek provided the fresh-water supply for San Nicolas Island during the time fieldwork was in progress. These sources were capable of supplying approximately 60,000 gallons of water per day in 1956. Before the wells were drilled in 1952, fresh water was collected from small springs along the contact between Eocene rocks and dune deposits exposed in the sea cliff at Thousand Springs.

Small springs of brackish water occur sporadically along several large faults on the south side of the island in the area between Seal Beach and Dutch Harbor. A spring of potable water flows from the contact between Eocene siltstone beds and Pleistocene dune deposits in the small gully about 2,000 feet northwest of hill 723 on the high western dune area. Fresh water also flows from several springs along the large sandy beach 1,500 feet east of hill 170 on Vizcaino Point. 
A supplementary water supply could be obtained by the construction of catchment basins in the large drainage systems where considerable runoff follows heavy rains. Diversion of additional gullies into the upper Tule Creek basin presumably would recharge the wells now in operation. Another source of water might be found in dune deposits that fill depressions in the Eocene bedrock surface in the dune-covered area southeast of Vizcaino Point. A deep water well was drilled at an altitude of about 560 feet on the flat terrace platform between Celery Creek and the main road intersection sometime during the period 1950-54. This well was drilled to a depth of about 600 feet but did not yield enough water to sufficiently increase the total water supply of the island.

\section{SUPPLEMENTARY DATA}

TABLE 7.-Observations by diving teams on operational dives [See pl. 4]

\begin{tabular}{|c|c|c|c|c|}
\hline Stati & $\begin{array}{l}\text { Jenth } \\
\text { (feet) }\end{array}$ & Strike & Dip & Gross lithology (diver's observation) \\
\hline & $30-40$ & N. $55^{\circ} \mathrm{W}$. & $20^{\circ} \mathrm{NF}$ & Interbedded sandstone and siltstone. \\
\hline & & & $17+ \pm^{\circ} \mathrm{NE}$ & Do. \\
\hline & -40 & N. $27^{\circ} \mathrm{W}$. & $21^{\circ} \mathrm{7}$ & Do. \\
\hline & $\begin{array}{l}20-45 \\
20-45\end{array}$ & N. $52^{\circ} \mathrm{W}$. & $\begin{array}{l}8^{\circ} \mathrm{NF} \text {. } \\
18^{\circ} \mathrm{NE} \text {. }\end{array}$ & $\begin{array}{c}\text { Not recor } \\
\text { Do. }\end{array}$ \\
\hline & $20-45$ & $\mathrm{~N} .65^{\circ} \mathrm{W}$ & $9^{\circ} \mathrm{N}$ & Interbedded sandstone and siltstone. \\
\hline & 70 & N. $33^{\circ} \mathrm{W}$. & $8^{\circ} 1$ & Do. \\
\hline & $\begin{array}{l}40 \pm \\
35\end{array}$ & $\begin{array}{l}\text { N. } 38^{\circ} \mathrm{W} \text {. } \\
\text { N. } 10^{\circ} \mathrm{W} \text {. }\end{array}$ & $\begin{array}{l}14^{\circ} \mathrm{N} \\
3+^{\circ}\end{array}$ & $\begin{array}{l}\text { Not recor } \\
\text { Sandston }\end{array}$ \\
\hline & 65 & N. $52^{\circ} \mathrm{F}$. & $5^{\circ} \mathrm{NW}$ & $\begin{array}{l}\text { Sands } \\
\text { Siltsto }\end{array}$ \\
\hline & $30-70$ & N. $15^{\circ} \mathrm{W}$. & $12^{\circ} \mathrm{NE}$ & under high sandst \\
\hline & 75 & E.-W. & $17^{\circ} \mathrm{s}$. & $\begin{array}{l}\text { Thin-bedded sandstone and siltstone } \\
\text { in sandstone cliff. }\end{array}$ \\
\hline & $\begin{array}{c}90 \\
105-120\end{array}$ & $\mathrm{~N} .30^{\circ} \mathrm{W}$. & $20^{\circ} \mathrm{SW}$. & Siltsto \\
\hline & $\begin{array}{c}105-1 \\
35-7\end{array}$ & 焉: & $\begin{aligned} 5^{\circ} \\
18^{\circ}\end{aligned}$ & \\
\hline & & N. $60^{\circ} \mathrm{F}$. & $13^{\circ} \mathrm{s}$. & Fine-grained thin- \\
\hline & $35-$ & N. 6 & $12^{\circ} \mathrm{S}$. & $\begin{array}{l}\text { Thin-bedded sandstone and silt- } \\
\text { stone. }\end{array}$ \\
\hline & $\begin{array}{l}35-70 \\
35-70\end{array}$ & $\begin{array}{l}\text { N. } 30^{\circ} \mathrm{F} \\
\text { N. } 72^{\circ} \mathrm{F}\end{array}$ & $\begin{array}{l}15^{\circ} \mathrm{SE} . \\
12^{\circ} \mathrm{S}\end{array}$ & $\begin{array}{l}\text { Sandstone. } \\
\text { Siltstone. }\end{array}$ \\
\hline & $45-65$ & N. $25^{\circ} \mathrm{F}$. & $10^{\circ} \mathrm{SH}$. & $\begin{array}{l}\text { Silstone. } \\
\text { Sandstone and siltstone. }\end{array}$ \\
\hline & $\begin{array}{l}45-65 \\
45-65\end{array}$ & N. $27^{\circ} \mathrm{F}$. & $11^{\circ} \mathrm{SF}$. & Siltstone \\
\hline & & NT 100 XT & $9^{\circ} \mathrm{S}$ & $\begin{array}{l}\text { Thin-bedded sandstone and silt- } \\
\text { stone. }\end{array}$ \\
\hline $\begin{array}{l}23 . \\
24 .\end{array}$ & $\begin{array}{l}60 \\
75\end{array}$ & $\begin{array}{l}\text { N. } 10^{\circ} \mathrm{W} \text {. } \\
\text { N. } 50^{\circ} \mathrm{E} \text {. }\end{array}$ & $\begin{array}{l}\mathbf{1 5 ^ { \circ }} \mathbf{E} \\
10 \pm^{\circ} \mathrm{NE}\end{array}$ & $\begin{array}{l}\text { Sandstone. } \\
\text { Thin-bedded sandstone and silt- }\end{array}$ \\
\hline & 50 & N. $70^{\circ} \mathrm{W}$. & $10 \pm^{\circ} \mathrm{N}$ & $\begin{array}{l}\text { stone. } \\
\text { Conglome }\end{array}$ \\
\hline & & & $10 \pm 01$ & Thin-bedd \\
\hline & $56-70$ & N. 7 & $6^{\circ} \mathrm{V}$ & Siltstone. \\
\hline & 45 & N. 2 & $\begin{array}{l}\text { Horizont } \\
9^{\circ} \mathrm{sE} \text {. }\end{array}$ & le and thin- \\
\hline & $60-65$ & N. & $16^{\circ} \mathrm{S}$ & $\begin{array}{l}\text { Thin-bedded siltstone with some } \\
\text { fine-grained sandstone. }\end{array}$ \\
\hline & $\begin{array}{l}60-65 \\
60-65\end{array}$ & $\begin{array}{l}\text { N. } 66^{\circ} \mathrm{E} \text {. } \\
\text { N. } 38^{\circ} \mathrm{E} \text {. }\end{array}$ & $\begin{array}{l}12^{\circ} \mathrm{S} . \\
15^{\circ} \mathrm{SE},\end{array}$ & $\begin{array}{l}\text { Do. } \\
\text { Do. }\end{array}$ \\
\hline & $60-65$ & N. $79^{\circ} \mathbf{E}$. & $10^{\circ} \mathrm{S}$ & Siltstone. \\
\hline & $\begin{array}{l}60-65 \\
60-65\end{array}$ & N. $53^{\circ} \mathrm{W}$. & $8^{\circ} \mathrm{SW}$. & Siltstone and shale. \\
\hline & & N. $64^{\circ} \mathrm{W}$ & $4^{\circ} \mathrm{N}$ & one and fine- \\
\hline & $\begin{array}{l}55 \\
60\end{array}$ & N. $38^{\circ} \mathbf{E}$. & $8^{\circ} \mathrm{SE}$. & $\begin{array}{l}\text { grained sandstone. } \\
\text { Interbedded siltstone and sandstone. } \\
\text { Siltstone and shale. }\end{array}$ \\
\hline & $\begin{array}{r}70 \\
55(?)\end{array}$ & $\begin{array}{l}\text { E. }- \text { W. } \\
\text { N. } 45^{\circ} \text { E. }\end{array}$ & $13^{\circ} \mathrm{S}$. & $\begin{array}{l}\text { Siltstone and thin-bedded sandstone. } \\
\text { Siltstone and thin-bedded }\end{array}$ \\
\hline & 69( & N. 27 & $17^{\circ} \mathrm{SW}$ & $\begin{array}{l}\text { srained sandstone. } \\
\text { Siltstone and thin-bedded }\end{array}$ \\
\hline 42. & & & & grained sandstone. \\
\hline & & & & $\begin{array}{l}\text { Interbedded siltstone and sandstone, } \\
\text { faulted. }\end{array}$ \\
\hline 44 & $\begin{array}{l}-80 \\
75 \\
65\end{array}$ & $\begin{array}{l}\text { N. } 60^{\circ} \mathrm{W} . \\
\text { N. } 58^{\circ} \mathrm{E} . \\
\text { N. } 78^{\circ} \mathrm{E} .\end{array}$ & $\begin{array}{l}9^{\circ} \mathrm{S} . \\
14^{\circ} \mathrm{SE} . \\
15^{\circ} \mathrm{S} .\end{array}$ & $\begin{array}{l}\text { Interbedded sandstone and siltstone. } \\
\text { Siltstone and shale. } \\
\text { Siltstone, shale, and some thin- }\end{array}$ \\
\hline $46 \ldots$ & 70 & N. $40^{\circ} \mathrm{E}$. & $9^{\circ} \mathrm{SE}$ & $\begin{array}{l}\text { bedded sandstone. } \\
\text { Siltstone with some thin-bedded }\end{array}$ \\
\hline & $\begin{array}{l}52 \\
68\end{array}$ & & & \\
\hline & 36 & N. $50^{\circ} \mathrm{W}$. & $\begin{array}{l}14^{\circ} \mathrm{NE} \text {. } \\
14^{\circ} \mathrm{NE} \text {. }\end{array}$ & $\begin{array}{l}\text { Siltstone and shale. } \\
\text { Interbedded sandstone and siltstone }\end{array}$ \\
\hline & $\begin{array}{l}62 \\
67\end{array}$ & $\begin{array}{l}\mathrm{N} .75^{\circ} \mathrm{E} \\
\mathrm{N} .35^{\circ} \mathrm{W}\end{array}$ & $5^{\circ} \mathrm{N}$ & Do. \\
\hline & 68 & & $4^{\circ} \mathrm{NW}^{\circ}$ & $\begin{array}{l}\text { Massive conglomerate. } \\
\text { Siltstone and shale, loose pebbles. }\end{array}$ \\
\hline & $\begin{array}{l}58 \\
52\end{array}$ & $\begin{array}{l}\text { N. } 70^{\circ} \mathrm{E} \text {. } \\
\text { N. } 17^{\circ} \mathrm{W} \text {. }\end{array}$ & $\begin{aligned} 6^{\circ} & \mathrm{S} \\
19^{\circ} & \mathrm{NE} .\end{aligned}$ & $\begin{array}{l}\text { Siltstone and shale. } \\
\text { Do. }\end{array}$ \\
\hline & & & & $\begin{array}{l}\text { Sandstone with thin-bedded silt- } \\
\text { stone. }\end{array}$ \\
\hline
\end{tabular}

TABLE 7.-Observations by diving teams on operational divesContinued

[See pl. 4]

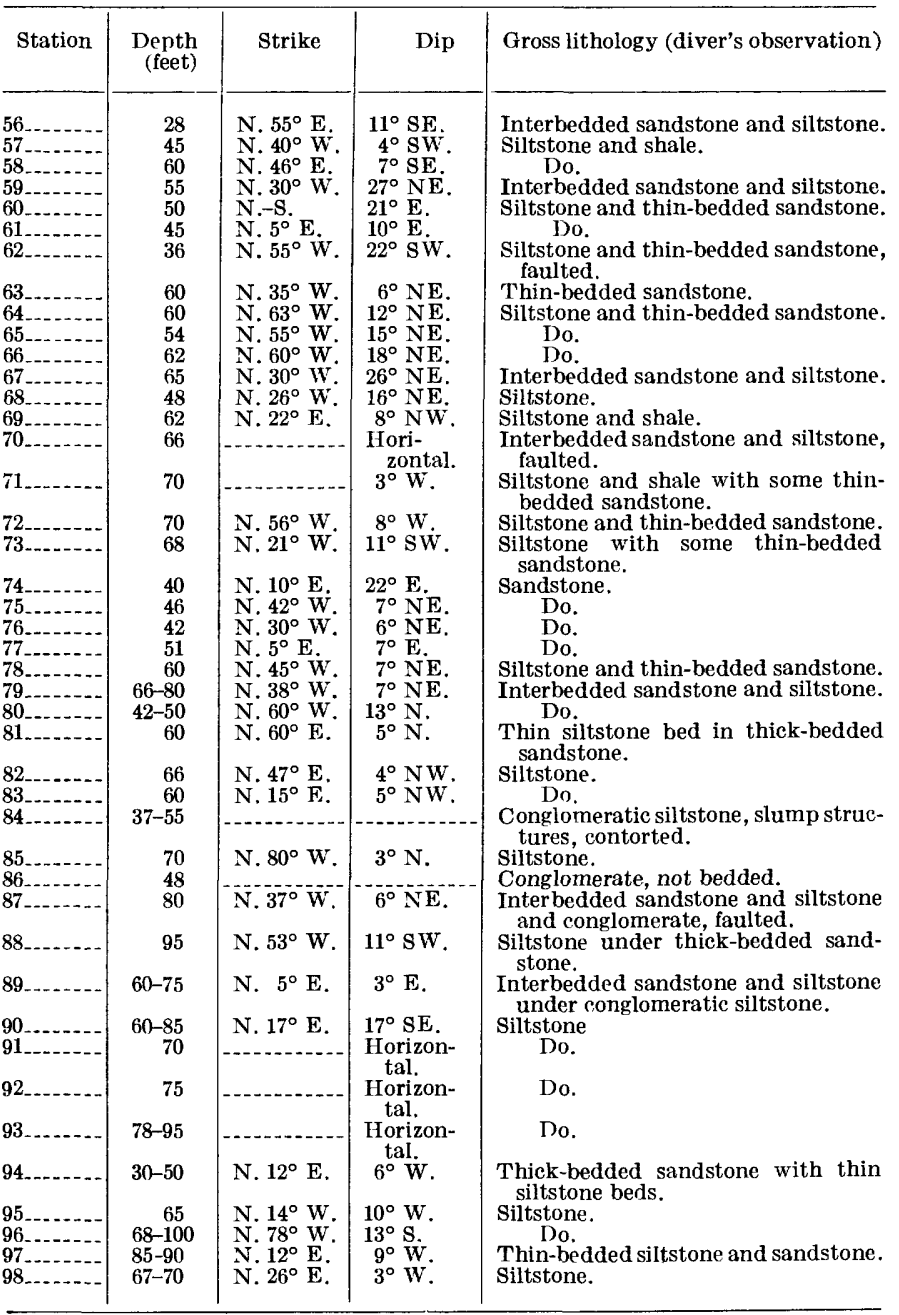

TABLE 8.-Eocene mollusk fossil locality descriptions [See pl. 3]

\begin{tabular}{|c|c|c|c|c|}
\hline $\begin{array}{l}\text { No. used } \\
\text { in this } \\
\text { report }\end{array}$ & $\begin{array}{c}\text { Per- } \\
\text { manent } \\
\text { U.S. } \\
\text { Geol. } \\
\text { Survey } \\
\text { no. }\end{array}$ & $\underset{\text { (feet) }}{\text { Altitude }}$ & Description of locality & $\begin{array}{c}\text { Collections made } \\
\text { by- }\end{array}$ \\
\hline E-1_.... & 21648 & $310 \pm$ & $\begin{array}{l}\text { Halfway up south side of } \\
\text { island north of Dutch Har- } \\
\text { bor, } 5,725 \text { feet south and } 4,525 \\
\text { feet west of lat } 33^{\circ} 14^{\prime} 30^{\prime \prime} \mathrm{N} \text {., } \\
\text { long } 119^{\circ} 28^{\prime} 00^{\prime \prime} \mathrm{W}^{\prime}\end{array}$ & $\begin{array}{l}\text { J. G. Vedder and } \\
\text { others in } 1955 .\end{array}$ \\
\hline E-2 $\ldots$ & 21649 & $230-240$ & $\begin{array}{l}\text { On first main ridge northeast } \\
\text { of Duteh Harbor, } 7,425 \text { feet } \\
\text { south and } 2,775 \text { feet west of } \\
\text { lat } 33^{\circ} 14^{\prime} 30^{\prime \prime} \text { N., long } \\
119^{\circ} 28^{\prime} 00^{\prime \prime} \mathrm{W} \text {. }\end{array}$ & $\begin{array}{l}\text { J. G. Vedder and } \\
\text { others in } 1955 \text { and } \\
1956 .\end{array}$ \\
\hline E-3..... & 21650 & $420 \pm$ & $\begin{array}{l}\text { On steep slope southeast of } \\
\text { Jackson Hill, } 3,825 \text { feet } \\
\text { south and } 1,950 \text { feet east of } \\
\text { lat } 33^{\circ} 14^{\prime} 30^{\prime \prime} \text { N., long } \\
119^{\circ} 30^{\prime} 30^{\prime \prime} \mathrm{W} \text {. }\end{array}$ & J. G. Vedder in 1955. \\
\hline $\mathrm{E}-4 \ldots \ldots$ & 21651 & $15-20$ & $\begin{array}{l}\text { Southwest of Vizcaino Point, } \\
9,675 \text { feet north and } 6,875 \\
\text { feet west of lat } 33^{\circ} 14^{\prime} 30^{\prime \prime} \mathrm{N} . \text {, } \\
\text { long } 119^{\circ} 33^{\prime} 00^{\prime \prime} \mathrm{W} \text {. }\end{array}$ & $\begin{array}{l}\text { R. M. Norris, J.G. } \\
\text { Vedder, and others } \\
\text { in } 1955 \text { and } 1956 .\end{array}$ \\
\hline $\mathrm{E}-5$ & 21652 & $10-15$ & $\begin{array}{l}\text { Vizcaino Point, } 12,500 \text { feet } \\
\text { north and } 7,975 \text { feet west of } \\
\text { lat } 33^{\circ} 14^{\prime} 30^{\prime \prime} \quad \mathrm{N} \text {., long } \\
119^{\circ} 33^{\prime} 00^{\prime \prime} \mathrm{W} \text {. }\end{array}$ & No collection. \\
\hline
\end{tabular}


TABLE 9.-Pleistocene fossil locality descriptions

\begin{tabular}{|c|c|c|c|c|}
\hline $\begin{array}{l}\text { No. used } \\
\text { in this } \\
\text { report }\end{array}$ & $\begin{array}{c}\text { Per- } \\
\text { manent } \\
\text { U.S. } \\
\text { Geol. } \\
\text { Survey } \\
\text { No. }\end{array}$ & $\underset{\text { (feet) }}{\text { Altitude }}$ & Description of locality & $\underset{\text { by }}{\text { Collections }}$ made \\
\hline SN-1.... & 21653 & $45-60$ & $\begin{array}{l}\text { Near Army Camp Beach, } \\
8,400 \text { feet north and } 3,650 \\
\text { feet east of lat } 33^{\circ} 14^{\prime} 30^{\prime \prime} \mathrm{N} \text {., } \\
\text { long } 119^{\circ} 30^{\prime} 30^{\prime \prime} \mathrm{E} \text {. }\end{array}$ & $\begin{array}{l}\text { J. G. Vedder, S. R. } \\
\text { Dabney, and D. J. } \\
\text { Milton in } 1955 .\end{array}$ \\
\hline SN-2 .... & 21654 & $730 \pm$ & $\begin{array}{l}\text { On main ridge east of hill } 818 \text {, } \\
4,075 \text { feet south and } 600 \text { feet } \\
\text { west of lat } 33^{\circ} 14^{\prime} 30^{\prime \prime} \text { N., long } \\
119^{\circ} 28^{\prime} 00^{\prime \prime} \mathbf{E} \text {. }\end{array}$ & J. G. Vedder in 1955. \\
\hline SN-3.... & 21655 & $735 \pm$ & $\begin{array}{l}\text { On main ridge east of hill } 818 \text {, } \\
3,300 \text { feet south and } 1,875 \text { feet } \\
\text { west of lat } 33^{\circ} 14^{\prime} 30^{\prime \prime} \text { N., long } \\
119^{\circ} 28^{\prime} 00^{\prime \prime} \mathbf{E} \text {. }\end{array}$ & $\begin{array}{l}\text { J. G. Vedder in } \\
1955 \text { and } 1956 .\end{array}$ \\
\hline SN-4_... & 21656 & $85 \pm$ & $\begin{array}{l}\text { Near Seal Beach, 2,950 feet } \\
\text { south and } 5,225 \text { feet east of } \\
\text { lat } 33^{\circ} 14^{\prime} 30^{\prime \prime} \quad \text { N., long } \\
119^{\circ} 33^{\prime} 00^{\prime \prime} \mathbf{E}\end{array}$ & J. G. Vedder in 1955. \\
\hline SN-5.... & 21657 & $840 \pm$ & $\begin{array}{l}\text { At the head of the first main } \\
\text { canyon west of Sand Dune } \\
\text { Canyon, } 1,850 \text { feet north and } \\
5,775 \text { feet east of lat } 33^{\circ} 14^{\prime} 30^{\prime \prime} \\
\text { N., Iong } 119^{\circ} 33^{\prime} 00^{\prime \prime} \mathrm{E} \text {. }\end{array}$ & Do. \\
\hline SN-6.... & 21658 & $815 \pm$ & $\begin{array}{l}\text { Near the head of the first main } \\
\text { canyon west of Jackson Hill, } \\
175 \text { feet south and } 600 \text { feet } \\
\text { west of lat } 33^{\circ} 14^{\prime} 30^{\prime \prime} \mathrm{N} \text {., } \\
\text { long } 119^{\circ} 30^{\prime} 30^{\prime \prime} \mathrm{E} \text {. }\end{array}$ & Do. \\
\hline SN-7.... & 21659 & $665 \pm$ & $\begin{array}{l}\text { East of hill } 818,2,850 \text { feet south } \\
\text { and } 875 \text { feet west of } \\
\text { lat } 33^{\circ} 14^{\prime} 30^{\prime \prime} \text { N., long } \\
119^{\circ} 28^{\prime} 00^{\prime \prime} \mathbf{E} \text {. }\end{array}$ & Do. \\
\hline SN-8.... & 21660 & $885 \pm$ & $\begin{array}{l}\text { Northwest of Jackson Hill, } \\
450 \text { feet north and } 1,200 \text { feet } \\
\text { west of lat } 33^{\circ} 14^{\prime} 30^{\prime \prime} \mathrm{N} \text {., } \\
\text { long } 119^{\circ} 30^{\prime} 30^{\prime \prime} \mathrm{E} \text {. }\end{array}$ & Do. \\
\hline SN-9.... & 21661 & $900+$ & $\begin{array}{l}\text { West of hill } 905,2,075 \text { feet } \\
\text { north and } 5,050 \text { feet west of } \\
\text { lat } 33^{\circ} 14^{\prime} 30^{\prime \prime} \text { N., long } \\
119^{\circ} 30^{\prime} 30^{\prime \prime} \mathrm{E} \text {. }\end{array}$ & $\begin{array}{l}\text { R. M. Norris and } \\
\text { J. G. Vedder in } \\
1956 \text {. }\end{array}$ \\
\hline SN-10.... & 21662 & $375 \pm$ & $\begin{array}{l}\text { On the edge of the first deep } \\
\text { canyon east of Celery Creek } \\
5,925 \text { feet north and } 6,350 \text { feet } \\
\text { east of lat } 33^{\circ} 14^{\prime} 30^{\prime \prime} \text { N., long } \\
19^{\circ} 30^{\prime} 30^{\prime \prime} \mathbf{E} \text {. }\end{array}$ & $\begin{array}{l}\text { J. G. Vedder, N. C. } \\
\text { Privrasky, and } \\
\text { G. P. Frymire } \\
\text { in 1956. }\end{array}$ \\
\hline $\mathrm{SN}-11 \ldots$ & 21663 & $590+$ & $\begin{array}{l}\text { East of upper Celery Creek, } \\
1,450 \text { feet north and } 5,775 \\
\text { feet east of lat } 33^{\circ} 14^{\prime} 30^{\prime \prime} \mathrm{N} . \text {, } \\
\text { long } 119^{\circ} 30^{\prime} 30^{\prime \prime} \mathrm{E} \text {. }\end{array}$ & $\begin{array}{l}\text { J. G. Vedder and } \\
\text { N. C. Privrasky } \\
\text { in } 1956 \text {. }\end{array}$ \\
\hline SN-12... & 21664 & $65-70$ & $\begin{array}{l}\text { At east end of the island, } 5,000 \\
\text { feet south and } 9,375 \text { feet east } \\
\text { of lat } 33^{\circ} 14^{\prime} 30^{\prime \prime} \text { N., long } \\
119^{\circ} 28^{\prime} 00^{\prime \prime} \mathrm{E} \text {. }\end{array}$ & Do. \\
\hline SN-13.-- & 21665 & $80-85$ & $\begin{array}{l}\text { East of Dutch Harbor, } 8,675 \\
\text { feet south and } 2,525 \text { west of } \\
\text { lat } 33^{\circ} 14^{\prime} 30^{\prime \prime} \text { N., long } \\
119^{\circ} 28^{\prime} 00^{\prime \prime} \mathbf{E} \text {. }\end{array}$ & J. G. Vedder in 1956. \\
\hline $\mathrm{SN}-14 \ldots$ & 21666 & $425 \pm$ & $\begin{array}{l}\text { West side of tributary to Min- } \\
\text { eral Creek, } 5,775 \text { feet north } \\
\text { and } 3,500 \text { feet east of lat } \\
33^{\circ} 14^{\prime} 30^{\prime} \mathrm{N} \text {., long } 119^{\circ} 30^{\prime} 30^{\prime \prime} \\
\mathbf{E} \text {. }\end{array}$ & $\begin{array}{l}\text { R. M. Norris in } \\
1955 .\end{array}$ \\
\hline SN-15_... & 21667 & $20 \pm$ & $\begin{array}{l}\text { On northwest coast, } 13,950 \\
\text { feet north and } 50 \text { feet east } \\
\text { of lat } 33^{\circ} 14^{\prime} 30^{\prime \prime} \text { N., long } \\
119^{\circ} 33^{\prime} 00^{\prime \prime} \mathrm{E} \text {. }\end{array}$ & Do. \\
\hline SN-16.... & 21668 & $470 \pm$ & $\begin{array}{l}\text { On bluff southwest of Army } \\
\text { Camp Beach, 8,075 feet } \\
\text { north and } 725 \text { feet east of lat } \\
33^{\circ} 14^{\prime} 30^{\prime \prime} \text { N., long } 119^{\circ} 30^{\prime} 30^{\prime \prime} \\
\text { E. }\end{array}$ & Do. \\
\hline
\end{tabular}

\section{REFERENCES CITED}

Addicott, W. O., and Emerson, W. K., 1959, Pleistocene invertebrates from Punta Cabras, Baja California, Mexico: Am. Mus. Novitates, no. 1925, 33 p.

Arnold, Ralph, 1903, The paleontology and stratigraphy of the marine Pliocene and Pleistocene of San Pedro, California : California Acad. Sci. Mem., v. 3, 420 p.

Bailey, E. H., 1954, Road log for Catalina Island: Geol. Soc. America field trip, 1954, 15 p.

Bailey, T. L., 1954, Geology of the western Ventura Basin, Santa Barbara, Ventura, and Los Angeles Counties: California Div. Mines Bull. 170, map sheet 4.
Beck, R. S., 1952, Correlation chart of Paleocene and Eocene on the Pacific coast, in Am. Assoc. Petroleum Geologists, Soc. Economic Paleontologists and Mineralogists, and Soc. Economic Geologists, Guidebook; field trip routes, oil fields, geology-Joint annual meeting, Los Angeles, Calif., 1952: p. 105.

Bormann, Mary, 1946, A survey of some west American Ocenebras, with description of a new species: The Nautilus, v. 60 , no. 2 , p. $37-43$.

Bowers, Stephen, 1890, San Nicolas Island: California State Mining Bur., 9th Ann. Rept. of State Mineralogist, 1889, p. 57-61.

Bradley, W. C., 1956, Carbon-14 date for a marine terrace at Santa Cruz, California: Geol. Soc. American Bull., v. 67, p. $675-678$.

Bremner, C. St. J., 1932, Geology of Santa Cruz Island, Santa Barbara County, California: Santa Barbara Mus. Nat. History, Occasional Papers, 33 p. 1933, Geology of San Miguel Island, Santa Barbara County, California: Santa Barbara Mus. Nat. History, Occasional Papers, 23 p.

Broecker, W. S., and Kulp, J. L., 1957, Lamont natural radiocarbon measurements, IV : Science, v. 126, p. 1324-1334.

Bruff, S. C., 1946, The paleontology of the Pleistocene molluscan fauna of the Newport Bay area, California: California Univ. Dept. Geol. Sci. Bull., v. 27, no. 6, p. 213-240.

Burch, J. Q., ed., 1944-46, Distributional list of the west American marine mollusks from San Diego, California, to the Polar Sea: Conch. Club Southern California Minutes, nos. 33-63.

Carter, G. F., 1957, Pleistocene man at San Diego: Baltimore, Md., Johns Hopkins Press, 400 p.

Cessac, M. L. de, 1882, Observations sur des fétiches de pierre sculptes en forme d'animaux découvert à l'île de San Nicolas (Californie) : Revue d'Ethnographie, v. 1, p. 30-40.

Clements, Thomas, and Emery, K. O., 1947, Seismic activity and topography of the sea floor off southern California : Seismol. Soc. America Bull., v. 37, p. 307-313.

Cockerell, T. D. A., 1938, Studies of island life: Colorado Univ. Studies, v. 26, no. 1, p. 3-20.

1940, The marine invertebrate fauna of the Californian islands: Pacific Sci. Cong., Berkeley, Palo Alto, and San Francisco, Calif., 1939, 6th, Proc., v. 3, p. 501-504.

Comstock, J. A., 1946, Contributions from the Los Angeles Museum-Channel Islands biological survey; Brief notes on the expeditions conducted between March 16, 1940, and December 14, 1941: Southern California Acad. Sci. Bull.. v. 45, pt. 2, p. 94-107.

Cooper, J. G., 1888, Catalogue of Californian fossils: California State Mining Bur., 7th Ann. Rept. of the State Mineralogist, 1887, p. 223-308.

Cooper, J. G., 1894, Catalogue of Californian fossils : California State Mining Bur. Bull. 4, 65 p.

Corey, W. H., 1954, Tertiary basins of southern California [pt. 8] in' chap. 3 of Johns, R. H., ed., Geology of Southern California : California Div. Mines Bull. 170, p. 73-83.

Crowell, J. C., 1957, Origin of pebbly mudstones: Geol. Soc. America Bull., v. 68, p. 993-1009.

Dall, W. H., 1921, Summary of the marine shellbearing mollusks of the northwest coast of America, from San Diego, California, to the Polar Sea, mostly contained in the collection of the United States National Museum. with illustrations of hitherto unfigured species: U.S. Natl. Mus. Bull. 122, 217 p. 
Dall, W. H., and Bartsch, Paul, 1909, A monograph of the West American pyramidellid mollusks: U.S. Natl. Mus. Bull. 68, 258 p.

Davidson, George, 1889, Pacific Coast--Coast Pilot of California, Oregon, and Washington: U.S. Coast Survey, 4th ed., 721 p., Washington, U.S. Government Printing Office.

Davis, W. M., 1933, Glacial epochs of the Santa Monica Mountains, California: Geol. Soc. American Bull., v. 44, p. 1041-1133.

Dawson, E. Y., 1951, A further study of upwelling and associated vegetation along Pacific Baja California, Mexico: Jour. Marine Research, v. 10, p. 39-58.

DeLong, J. H., Jr., 1941, The paleontology and stratigraphy of the Pleistocene at Signal Hill, Long Beach, California: San Diego, Nat. History Trans., v. 9, no. 25, p. 229-252.

Dill, R. F., and Shumway, George, 1954, Geologic use of selfcontained diving apparatus: Am. Assoc. Petroleum Geologists Bull.. v. 38, p. 148-157.

Emerson, W. K., 1956a, Pleistocene invertebrates from Punta China, Baja California, Mexico, with remarks on the composition of the Pacific Coast Quaternary faunas: Am. Mus. Nat. History Bull., v. 3, art. 4, p. 317-342.

- 1956b, Upwelling and associated marine life along Pacific Baja California, Mexico: Jour. Paleontology, v. 30, p. 393-397.

Emerson, W. K., and Addicott, W. O., 1953, A Pleistocene invertebrate fauna from the southwest corner of San Diego County, California: San Diego Soc. Nat. History Trans., v. 11 , no. 17 , p. $429-444$.

Emery, K. O., 1950, Ironstone concretions and beach ridges of San Diego County, California: California Jour. Mines and Geology, v. 46, p. 213-222.

- 1954, General geology of the offshore area, southern California [pt.] 7 in chap. 2 of Johns, R. E., ed., Geology of southern California: California Div. Mines Bull. 170, p. 107-111.

__ 1958, Shallow submerged marine terraces of southern California: Geol. Soc. American Bull., v. 69, p. 39-60.

Emery, K. O., and Shepard, F. P., 1945, Lithology of the sea floor off southern California: Geol. Soc. American Bull., v. 56, p. 431-478.

Gabriel, Alton. and Cox, E. P., 1929, A staining method for the quantitative determination of certain rock minerals: Am. Mineralogist, v. 14, p. 290-292.

Grant, U. S., 4th, and Gale, H. R., 1931, Catalogue of the marine Pliocene and Pleistocene Mollusca of California: San Diego Soc. Nat. History Mem., v. 1, 1036 p.

Grant, U. S., 4th, and Strong, A. M., 1934, Fossil mollusks from the vertebrate-bearing asphalt deposits at Carpinteria. California: Southern California Acad. Sci. Bull.. v. 33. pt. 1, p. 7-11.

Gudde, E. G., 1949, California place names: Berkeley, Calif., California Univ. Press, 431 p.

Hanna, M. A., 1926, Geology of the La Jolla quadrangle, California: California Univ. Dept. Geol. Sci. Bull., v. 16, p. 187-246.

Hardacre, E. C., 1880, Eighteen years alone: Scribner's Monthly, v. 20, p. 657-664; reprinted 1950 by Santa Barbara, Calif., Schauer Printing Studio Press, 22 p.

Hedgpeth, J. W., 1957, Classification of marine environments, chap. 6 of Ladd, H. S., ed., Paleoecology: Geol. Soc. America Mem. 67, p. 93-100.

Hemphill, Henry, 1901, A contribution to west coast conchology: The Nautilus, v. 14, no. 11, p. 121-125; no. 12. p. 136-140.
Henshaw, H. W., 1879, Translation from the Spanish of the account by the pilot Ferrel of the voyage of Cabrillo along the west coast of North America in 1542: U.S. Geog. Surveys west of the 100th Meridian (Wheeler), app., pt. 1 , v. 7 , p. 293-314.

Hertlein, L. G., and Grant, U. S., 4th, 1944a, The geology and paleontology of the marine Pliocene of San Diego, California : San Diego Soc. Nat. History Mem., v. 2, pt. 1, 72 p. 1944b, The Cenozoic Brachiopoda of western North America : California Univ., Los Angeles, Calif., Pub. Math. and Phys. Sci., v. 3, 236 p.

Holder, C. F., 1910, The Channel Islands of California : Chicago, Ill., A. C. McClurg, 353 p.

Holman, W. H., 1958, Correlation of producing zones of Ventura Basin oil fields, in Am. Assoc. Petroleum Geologists and Soc. Economic Paleontologists and Mineralogists, A guide to the geology and oil fields of the Los Angeles and Ventura regions-Annual meeting, Los Angeles, Calif.. 1958: Am. Assoc. Petroleum Geologists, Pacific Section, p. 191-199.

Holzman, J. E., 1952, Subinarine geology of Cortes and Tanner Banks: Jour. Sed. Petrology, v. 22, p. 97-118.

Hoots, H. W., 1931, Geology of the eastern part of the Santa Monica Mountains, Los Angeles County, California: U.S. Geol. Survey Prof. Paper 165-C, p. 83-134.

Howard. Hilegarde, 1955, New records and a new species of Chendytes, an extinct genus of diving geese: The Condor, v. 57 , no. 3 , p. $135-143$.

Hubbs, C. L., 1948, Changes in the fish fauna of western North America correlated with changes in ocean temperature: Jour. Marine Research, v. 7, p. 459-482.

Ingles, L. G., 1954, Mammals of California and its coastal waters: Stanford, Calif., Stanford Univ. Press, 396 p.

Jahns, R. H., 1954, Geology of the Peninsular Range province, southern California and Baja California [pt. 3] in chap. 2 of Johns, R. H., ed., Geology of Southern California : California Div. Mines Bull. 170, p. 29-52.

Keen, A. M., 1937, An abridged check list and bibliography of west North American marine Mollusca : Stanford, Calif., Stanford Univ. Press. 87 p.

Kemnitzer, L. E., 1936, The geology of San Nicolas Island, California [abs.] : Am. Assoc. Petroleum Geologists Bull., v. 20, p. 1519.

Kew, W. S. W., 1927, Geologic sketch of Santa Rosa Island, Santa Barbara County, California: Geol. Soc. America Bull., v. 38, p. 645-654.

Kroeber, A. L., 1953, Handbook of the Indians of California : Berkeley, Calif., California Book Co., 995 p.

Kuenen, P. H., 1950, Marine geology: New York, John Wiley \& Sons, $568 \mathrm{p}$.

Kulp, J. F., Tryon, L. E., Eckelman, W. R., and Snell, W. A., 1952, Lamont natural radiocarbon measurements, II : Science, v. 116, p. 409-414.

Laiming. B. G., 1940, Some foraminiferal correlations in the Eocene of San Joaquin Valley, California: Pacific Sci. Cong., 6th. Berkeley, Palo Alto, and San Francisco, Calif., 1939, Proc., v. 2, p. 535-568.

Lawson, A. C., 1893, The post-Pliocene diastrophism of the coast of southern California: California Univ. Dept. Geol. Sci., v. 1, p. 115-160.

Lowe, H. N., 1903, Notes on the mollusk fauna of San Nicholas [sic]: The Nautilus, v. 17, no. 6, p. 66-69.

Marks, J. G., 1943, Type locality of the Tejon formation: California Div. Mines Bull. 118, p. 534-538. 
Meighan, C. W., and Eberhart, Hal, 1953, Archeological resources of San Nicholas Island, California: Am. Antiquity, v. 19 , p. 109-125.

Menard, H. W., Dill, R. F., Hamilton, E. L., Moore, D. G., Shumway, George, Silverman, Maxwell, and Stewart, H. B., 1954, Underwater mapping by diving geologists: Am. Assoc. Petroleum Geologists Bull., v. 38, p. 129-147.

Namais, Jerome, 1959, Recent seasonal interactions between North Pacific waters and the overlying atmospheric circulation: Jour. Geophys. Research, v. 64, p. 631-646.

Natland, M. L., 1957, Paleoecology of west coast Tertiary sediments, chap. 19 of Ladd, H. S., ed., Paleoecology : Geol. Soc. America Mem. 67, p. 543-572.

Norris, R. M., 1952, Recent history of a sand spit at San Nicolas Island, California: Jour. Sed. Petrology, v. 22, p. 224-228.

Oldroyd, I. S., and Grant, U. S., 4th, 1981, A Pleistocene molluscan fauna from near Goleta, Santa Barbara County, California: The Nautilus, v. 44, no. 3, p. 91-94.

Olmsted, F. H., 1958, Geologic reconnaissance of San Clemente Island, California: U.S. Geol. Survey Bull. 1071-B, p. 55-68.

Orr, P. C., 1951, Ancient population centers of Santa Rosa Island : Am. Antiquity, v. 16, p. 221-226.

Orr, W. L., Emery, K. O., and Grady, J. R., 1958, Preservation of chlorophyll derivatives in sediments off southern California : Am. Assoc. Petroleum Geologists Bull., v. 42, no. 5, p. 925-962.

Pettijohn, F. J., 1957, Sedimentary rocks : New York, Harper \& Bros., 526 p.

Putnam, W. C., 1942, Geomorphology of the Ventura region, California : Geol. Soc. America Bull., v. 53, p. 691-754. - 1954, Marine terraces of the Ventura region and the Santa Monica Mountains, California [pt.] 7 in chap. 5 of Jahns, R. H., ed., Geology of southern California: California Div. Mines Bull. 170, p. 45-48.

Raitt, R. W., 1949, Studies of ocean-bottom structure off southern California with explosive waves [abs.]: Geol. Soc. America Bull., v. 60, p. 1915.

Rand, W. W., 1931, Preliminary report of the geology of Santa Cruz Island, Santa Barbara County, California, in Mining in California : California Div. Mines, v. 27, no. 2, p. 214-219.

Redwine, L. E., chm., and others, 1952, Cenozoic correlation section paralleling north and south margins western Ventura Basin from Point Conception to Ventura and Channel Islands, California: Am. Assoc. Petroleum Geologists, 2 sheets.

Reed, R. D., 1928, The occurrence of feldspar in California sandstones: Am. Assoc. Petroleum Geologists Bull., v. 12, p. 1023-1024.

1933, Geology of California : Tulsa, Okla., Am. Assoc. Petroleum Geologists, 355 p.

Ricketts, E. F., and Calvin, Jack, 1952, Between Pacific tides, 3d ed. (revised by J. W. Hedgpeth) : Stanford, Calif., Stanford Univ. Press, $502 \mathrm{p}$.

Rubin, Meyer, and Suess, H. E., 1955, U.S. Geological Survey radiocarbon dates, II : Science, v. 121 , p. $481-488$.

1956, U.S. Geological Survey radiocarbon dates, III : Science, v. 123, p. $442-448$.

Schoellhamer, J. E., and Kinney, D. M., 1953, Geology of portions of Tumey and Panoche Hills, Fresno County, California: U.S. Geol. Survey Oil and Gas Inv. Map OM-128.
Schoellhamer, J. E., and Woodford, A. O., 1951, The floor of the Los Angeles basin, Los Angeles, Orange, and San Bernardino Counties, Califoruia: U.S. Geol. Survey Oil and Gas Inv. Map OM-117.

Scholl, D. W., 1959, Exposures of San Onofre breccia on Anacapa Island, California : Am. Assoc. Petroleum Geologists Bull., v. 43, p. 222-223.

Schumacher, Paul, 1877, Researches in the Kjokken-moddings and graves of a former population of the Santa Barbara Islands and the adjacent mainland: U.S. Geol. and Geog. Survey of the Territories Bull. (Hayden), v. 3, p. 37-56.

Shepard, F. P., and Emery, K. O., 1941, Submarine topography off the California Coast-canyons and tectonic interpretation: Geol. Soc. America Spec. Paper 31, 171 p.

Shepard, F. P., and Wrath, W. F., 1937, Marine sediments around Catalina Island: Jour. Sed. Petrology, v. 7, p. 41-50.

Smith, A. G., and Gordon, Mackenzie, Jr., 1948, The marine mollusks and brachiopods of Monterey Bay, California, and vicinity : California Acad. Sci. Proc., v. 26, no. 8, p. 147-245.

Smith, W. S. T., 1898, A geological sketch of San Clemente Island: U.S. Geol. Survey 18th Ann. Rept., 1896-97, pt. 2 , p. $459-496$.

1900, A topographic study of the islands of southern California : California Univ. Dept. Geol. Sci., v. 2, p. 179-230.

Stipp, T. F., 1943, Simi oil field: California Div. Mines Bull. 118 , p. $417-423$.

Stock, Chester, 1937, An Eocene titanothere from San Diego County, California, with remarks on the age of the Poway conglomerate: Natl. Acad. Sci. Proc., v. 23, p. 48-53.

Sverdrup, H. U., Johnson, M. W., and Fleming, R. H., 1942, The oceans, their physics, chemistry, and general biology: New York, Prentice Hall Inc., $1060 \mathrm{p}$.

Trask, P. D., 1932, Origin and environment of source sediments of petroleum: Houston, Tex., Gulf Publishing Co., p. 71-72.

Upson, J. E., 1949, Late Pleistocene and Recent changes of sea level along the coast of Santa Barbara County, California: Am. Jour. Sci., v. 247, no. 2, p. 94-115.

- 1951, Former marine shorelines of the Gaviota quadrangle, Santa Barbara County, California: Jour. Geology, v. 59 , p. $415-446$.

Valentine, J. W., 1955, Upwelling and thermally anomalous Pacific Coast Pleistocene molluscan faunas: Am. Jour. Sci., v. 253, p. 462-474.

1956, Upper Pleistocene Mollusca from Potrero Canyon, Pacific Palisades, California: San Diego Soc. Nat. History Trans., v. 12, p. 181-205.

— 1957, Late Pleistocene faunas from the northwestern coast of Baja California, Mexico: San Diego Soc. Nat. History Trans., v. 12, no. 16, p. 289-308.

— 1958, Late Pleistocene megafauna of Cayucos, Calffornia, and its zoogeographic significance: Jour. Paleontology, v. 32, p. 687-696.

Valentine, J. W., and Meade, R. F., 1958, California Pleistocene paleotemperatures [abs.]: Soc. Econ. Paleontologists and Mineralogists, 32d Ann. Meeting, Los Angeles, Calif., tech. sess. program, p. 57.

Vedder, J. G., Schoellhamer, J. E., and Israelsky, M. C., 1956, Preliminary report on the geology of San Nicolas Island, California : U.S. Geol. Survey open-file report, $15 \mathrm{p}$.

Vedder, J. G., Yerkes, R. F., and Schoellhamer, J. E., 1957, Geologic map of the San Joaquin Hills-San Juan 
Capistrano area, Orange County, California: U.S. Geol. Survey Oil and Gas Inv. Map OM-193.

Walton, W. R., 1955, Ecology of living benthonic Foraminifera, Todos Santos Bay. Baja California: Jour. Paleontology, v. 29 , p. $952-1018$.

Weaver, C. E., chm., and others, 1944, Correlation of the marine Cenozoic formations of western North America: Geol. Soc. American Bull., v. 55, p. 569-598.

Webb, R. W., 1937, Paleontology of the Pleistocene of Point Loma, San Diego County, California: San Diego Soc. Nat. History Trans., v. 8, no. 24, p. 337-348.

Wentworth, C. K., 1922, A scale of grade and class terms for clastic sediments: Jour. Geology, v. 30, p. 377-392.

Whitney, J. D., 1865, Geological Survey of California ; Report of progress and synopsis of the fieldwork from 1860-1864: California Geol. Survey, Geology, r. 1, 498 p.

Willett, George, 1937a, An upper Pleistocene fauna from the Baldwin Hills, Los Angeles County. California: San Diego Soc. Nat. History Trans., v. 8, no. 30, p. 379-406.

- 1937b, Report on a Pleistocene molluscan fauna at Capistrano Beach, Orange County, California: Southern California Acad. Sci. Bull., v. 36, p. 105-107.

Williams, Howel, Turner, F. J., and Gilbert, C. M., 1954, Petrography-An introduction to the study of rocks in thin sections: San Francisco, Calif., W. H. Freeman and Co., 406 p.
Woodford, A. O., 1924, The Catalina metamorphic facies of the Franciscan series: California Univ. Dept. Geol. Sci. Bull., v. 15, p. 49-68.

1925, The San Onofre breccia; its nature and origin: California Univ. Dept. Geol. Sci. Bull., v. 15, p. 159-280.

Woodring, W. P., 1935, Fossils from the marine Pleistocene terraces of the San Pedro Hills, California: Am. Jour. Sci., 5th ser., v. 29, no. 171, p. 292-305.

1952. Pliocene-Pleistocene boundary in California Coast Ranges: Am. Jour, Sci., v. 250, p. 401-410.

- 1957, Marine Pleistocene of California: Geol. Soc. America Mem. 67, v, 2, p. 589-597.

Woodring, W. P., and Bramlette, M. N., 1950, Geology and paleontology of the Santa Maria district, California: U.S. Geol. Survey Prof. Paper 222, 185 p.

Woodring. W. P., Bramlette, M. N., and Kew, W. S. W., 1946, Geology and paleontology of Palos Verdes Hills, California : U.S. Geol. Survey Prof. Paper 207, 145 p.

Woodring, W. P., and Popenoe, W. P., 1954, Paleocene and Eocene stratigraphy of northwestern Santa Ana Mountains. Orange County, California: U.S. Geol. Survey Oil and Gas Inv. Prelim. Chart 12.

Yates, L. G., 1896, The deserted homes of a lost people : Overland Monthly, 2d ser., v. 27, p. 538-544.

Zeuner, F. E., 1945, The Pleistocene period, its climate, chronology, and faunal successions: London, Ray Society, 322 p. 


\section{N D E X}

A Page

Acanthina lugubris.................... 44, 50

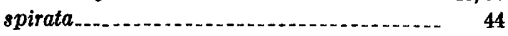
punctulata................ 44, 55

Accessibility _.................................. 1-2

Acila decisa . .

Acknowledgments......................... 2-3

Acmaea asmi.

digitalis................................... 40

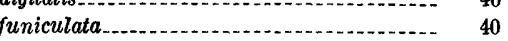

insessa

instabilis

limatula................... 40,55

mörchii._.............................. 41

mitra............................. 40, 50, 55

pelta

nacelloides................................. 55

scabra . . .

scutum............................... 40

n. sp......... 40

Acteocina culcitella..

Aequipecten circularis...

circularis aequisulcatus

Agaronia mathewsonii........................... 37

Aletes squamigerus......................... 42

Algae, red, radio carbon dates. ............. 53

Alluvium.................................... 32-33

Alvania acutelirata......................... 42 almo bakeri....................................... 41

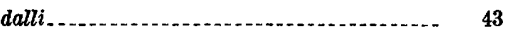
dinora

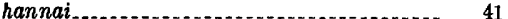

keenae.............. 41

lirata. . .

oldroydae .............................. 42

purpurea............................. 40

n. sp ........................................ 42

Amaurellina clarki........................ 37

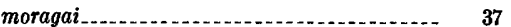

Amphimorphina californica

Amphineura............................ 46-49, 55

Amphissa columbiana........................ 44,50 versicolor incisa.......................................... 45

Amphithalamus inclusus .................... 42, 50 tenuis

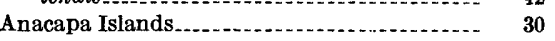

Anadara multicostata...................... 46,50

Analyses, Eocene sandstone . ................ 22-25

Anita shale.................................. 27

Annelida. .................................... 48-49 Anomalous occurrence of restricted-depth

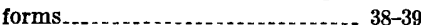

forms
Arca sisquocensis

Archeological sites........................... $\quad 55$

Architectonica cognata..................... 37 ullreyana.............................. 37

Arene acuticostata

acuticostata bristolae.................. 40

radiata $\ldots \ldots$.......................... 40

Assiminea translucens...................... 42

Astraea gibberosa undosa $\ldots \ldots \ldots \ldots, \ldots 5,56$

B

Balanophyllia elegan

Balanus nubilis.

tintinnabulum californicus

sp.

48

48

48

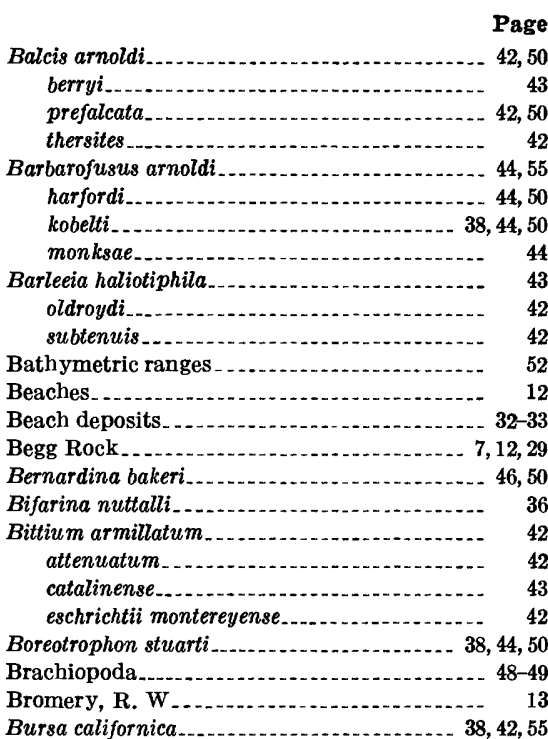

\section{C}

Caecum dalli californicum .................................... 42

Calicantharus fortis .

Caliche deposits............................... 32

Calliostoma ligatum ........................... 40,50

Callistochiton crassicostatus ....................... 46

Caly ptraea contorta

fastigiata................................... 42,50

mammilaris.................................. 43

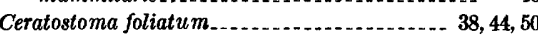

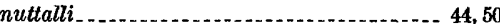

Cerithiopsis grippi_........................ 42

unidentified forms......................... 42

Chama pellucida................................ 46

Channel Islands.............................. 5

Chlamys hastatus. .......................... 46, 50

hastatus hericius .................................. 470

Cibicides sp.................................... 36

Cirripedia............................... 48-49, 55

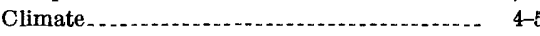

Clinocardium nuttallii........................ 46,50

Coelenterata $48-49$

Coleophysis harpa

Conus californicus. . .

Coronula diadema......................... 55

Correlation, age and faunal................. 52-53

Cortes Bank

Cozy Dell formation........................

Crepidula aculeata adunca................................ 42 excavata . . . . onyx ...................................... 42 perforans.............................. 42 princeps . .

Crepipatella lingulata ........................ 42

Crucibulum spinosum

Cryptochiton stelleri...................... 48,55,56

Cryptoconus cooperi........................... 37

Cryptonatica clausa......................... 42

Culture............................. 3-4

Cumingia californica........ 46

Cyanoplax dentiens............................. 46

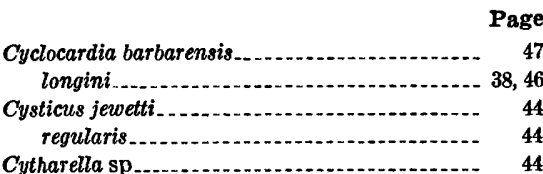

\section{D}

Daphnella fuscoligata

Davidson, George, cited...........................

Dendraster excentricus............................ 48

Dendrochiton thamnopora..................... 46

Dentalium cooperi......................... 37 semipolitum

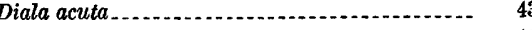

marmorea................................ 42

Diodora aspera

Diplodonta orbella.......................... 46

Dodecaceria fistula cola........................... 48

Drainage ..................................... 11

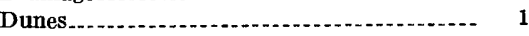

E

Echinodermata............................ 48-49

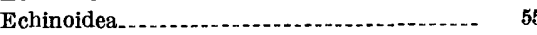

Economic geology

Elachisina grippi

Emery, K. O., cited............... 5

Eocene Foraminifera . . . . .

Eocene megafossils. . . . . . . . . . . . . . . .

Eocene series analyses....................... 22-25 correlation

description of mapped units.............. 15-22 general features............................. 13-15 source rocks................................ 25

Eolian sand . ............................. 13, 30-32

Epilucina californica......................... 46, 55 Epitonium indianorum
tinctum

Erato vitellina.................................. 55

Euspiru nuciformis

F

Fartulum occidentale ................... 42, 50 orcutti .

Faults....................................... 5, 7, 34

Features of island ........................... 8

Field work

Fissurella volcano........................ 40

Folds.......................................... 35

Foraminifera......... 36

Fossil localities....................... 36-38, 58-59

Fossils from marine terrace deposits, age and faunal correlation................ 52-53 annotated checklist........................ 38, 40-49

Fusinus merriami

Fusus portolaensis

G

Gari californica Gastropoda Geographic ranges.......................... 52

Geomorphology

Gibberulina pyriformis......................... 44

Glans subquadrata. . . .

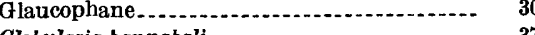

Globularia hannabali ...................

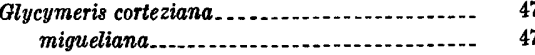

migueliana 


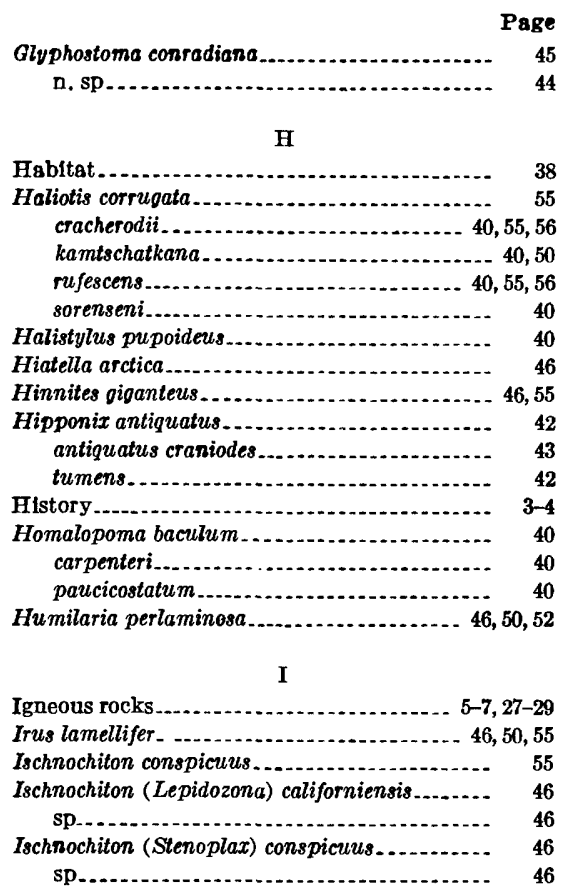

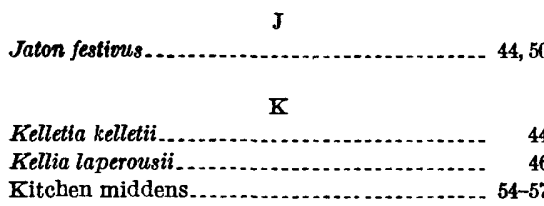

L

La Jolla, Calif., Eocene rocks near........... 25, 27

La Jolla formation....................... 27

Lacuna carinata. . unifasciata.................................. 40

Laevicardium elatum

Lamellaria rhombica.

Land bridge.................................. 10

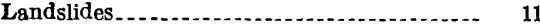

Lasaea cistula

Latirus nightingalei............. 37

Liotia fenestrata........................... 40

Littorina planaxis........................... scutulata...................................... 40

Liveoak member.................. 25

Llajas formation ................................. 27

Location............................................ 1-2

Lottia gigantea

Loxotrema turritum....................... 37

Lucapinella callomarginata.................. 40

Lunatia lewisii ............... 42,55

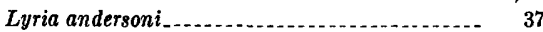

Macron lividus ...................... 44, 50

Mangelia interfossa........................ 44, 50

nitens ...................................... 44

rhyssa.................... 44,50

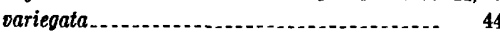

Matilija formation......................... 27

Maxwellia gemma ............................. 44

Megafossils, Eocene........ 36-37

Megatebennus bimaculatus................. 40

Megathura crenulata. ........................ 40,55

Metaxia convexa.............................. diadema...

Methods.

(1)

Micrarionta sodalis ........................... 46

Milneria minima........................... 46
Page

Miocene rocks, regional distribution ........... 12 Santa Barbara, San Clemente, and Santa Cruz Islands.

Miodontiscus prolonoatus

Mitra idae idae montereyi............................. 45

Mitrella tuberosa.............................. 44 carinata

gausapata$$
\text { filosa. }
$$
gracilior

Modiolus fornicatus.

Monterey shale, rocks resembling............. 12

Mopalia ciliata

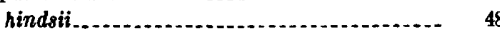

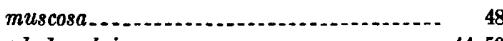

Morula lugubris ............................... 44, 50

Mytilus californianus.................... 46, 55, 56

\section{$\mathbf{N}$}

Nassarius mendicus cooperi. perpinouis.

Neverita secto

Norrisia norrisii ............................... 40,55

\section{0}

Observations by diving teams. $.14,18,30,33,35-36,58$

Ocenebra beta.............................. 44 circumtexta............................. 44,55 foveolata................. 44 interfossa................................... 44 clathrata.............................. 44,50 lurida.................................. 44,50 munda............................. 44, 50

subangulata.............................. 44

Odostomia altina.............................. 42

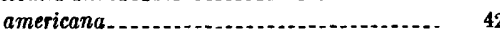
eugena..................................... 42

i0

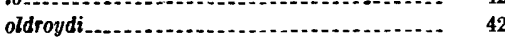
phanella................................ 42 sanctorum................................ 43 sapia....................................... 44 tenuisculpta terricula...

42 viroinalis Offshore structure observed by divers........ 35-36

Olivella baetica . ............................. 45,55

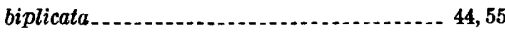
pedroana.......... 44

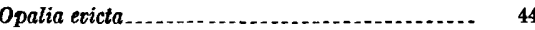
wroblewskyi chacei.......................... 44,50

Ophiodermella ophioderma

Ostrea lurida

stewarti.................................... 37

\section{$\mathbf{P}$}

Pachydesma crassatelloides _.................. 55 Paleoecology, inferences...-............... 38-52 Paleontology, age and faunal correlation...... 36-37,

Eocene Foraminifera. ...................... Eocene megafossils. ...................... 36-37 fossils from marine terrace deposits . . . . . . 37-51 Paleotemperatures . . Panope generosa ............... 39, 46

Parapholas californica.......................... 46, 50

Parvilucina tenuisculpta................... 46

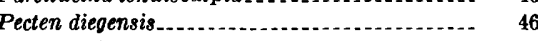

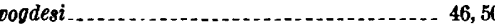

Pelecypoda......................... 37, 46-47,50,55

Penitella penita................ 46, 50

Petaloconchus anellum...

complicatus.

Petricola carditc

Petroleum possibilities
Placiphorella velato

Page

Plectina garzaensis

Pleistocene and Recent series, caliche deposits.

windblown sand

Pleistocene series, terrace deposits.......... 29-30

Pleurofusia lindavistaensis_................... 37

Potamides carbonicola........................ 37

Powsy conglomerate................ 27

Progabbia cooperi........................ 38, 44, 50, 55

Protothaca staminea........................... 46,55

Pseudomelatoma grippi......................... 44

torosa

Puncturella cooperi.

Pupillaria optabilis . . . . . .

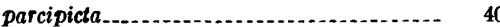

pupilla.............. 38, 40, 50

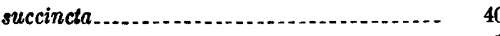

Purpose

Pusula californiana. solandri.

Quaternary system, Pleistocene and Recent series, undifferentiated........ 30-32

Pleistocene series.......................... 29-30

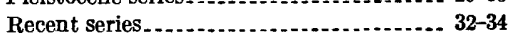

Quickella rehderi............... 46

\section{$\mathbf{R}$}

Radiocarbon date, kitchen midden............ 57 red algae ................................ 53 terrace localities.............................. 53

Recent series, beach deposits and alluvium... 32-33 offshore shelf and slope deposits.......... 33-34

Reed Canyon siltstone member.............. 25

Rissoina aequisculpta......................... 40,50 bakeri.................................. 40 coronadoensis............................... 40, 50 dalli............................................ 40

hannai Robulus welchi.................................... 36 Rose Can yon shale......................... 27

San Clemente Island ...................... 5, 29,35 San Joaquin Valley, Eocene rocks in.......... San Miguel Island..................... 5, 12, 15, 25, 3 San Nicolas Basin ............................ 7, 3 San Onofre breccia.......................... 30 Sand Dune Canyon area................... 17, 18 Santa Barbara Island...................... 5, 29, 35 Santa Catalina Island $\ldots \ldots \ldots \ldots \ldots \ldots, 6,25,30$ Santa Cruz Basin....................... 7, 12,35 Santa Cruz Island.................. 5, 7, 25, 29, 30,57 Santa Monica Mountains ................... 5,51 Santa Rosa-Cortes Ridge............. 7, 10, 12, 30,35 Santa Rosa Island. Santa Susana formation ....................... 27 Santa Ynez Mountains, Eocene rocks in...... $\quad 25$ Santiago formation ........................... 27 Saxidomus nuttalli . ........................ 39, 46 Scaphopoda.............................. 37, 48-49 Schizothaerus nuttalli Scope

Searlesia dira ................................ 44, 50 Sedimentary rocks, Eocene.................... 13-27 Septifer bifurcatus................................ 46,55 Serpula octoforis............................ 48 Setting, geomorphic, of island platform...... 7-8 Seila montereyensis........................... 42 Siphonaria brannani.......................... 46 Spiroglyphus lituellus........................ 42,50 Spisula planulata........................... 39,46 Stratigraphy, concealed rocks.............. 12-13 general features of the exposed rocks....... 13 Quaternary system....................... 29-34 regional .............. $5-7$ Tertiary system............................. 13-29 
Page

Strongylocentrotus franciscanus.............. 48, 55, 56
purpuratus

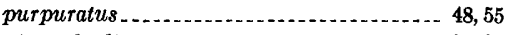

Structure, faults .............................. 34-35

Structure, folds.............................. 35

Structure, offshore structure observed by divers.............................. 35-36

Structure, regional

Surcula praeattenuata

Surculites mathewsonii _................... 37

Surface-water paleotemperatures.............. 39,51

$\mathrm{T}$

Tanner Bank ............................... 6-7

Tegula aureotincta.................... 40,50 brunnea..................... 40,50,55,57 fiuctuosa

funebralis........................... 40,55,57

gaillina multifilosa ..................... 40,50 montereyi.................... 40,50,55

pulligo

40

Tejon Eocene sandstones... ................. 25

Tellina salmonea.......................... 39,46,50

Temperature, monthly mean 4

Terebra (Strioterebrum) lucana ............... 44,50

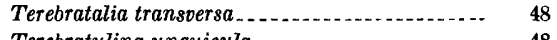

Terebratulina unguicula

Terrace deposits, fossils $\ldots \ldots \ldots \ldots \ldots \ldots$ vicinity of Celery Creek
Page

Terrace faunas, paleoecologic comparisons.... 51-52 Terraces, age limit

geomorpholog 8

Tertiary system, Eocene series.................. 13-27

igneous rocks.............................. 27-29

Tetraclita squamosa rubescens........... 48

Thais emarginata

emarginata ostrina.......................... 45

Thracia curta.

Torrey sand

quadragenarium

Transennella tantilla..........................

Tricolia pulloides............................. rubrilineata.

Trigoniocardia biangulata

Trimusculus reticulatus....................... 46,55

Triphora pedroana

Tubulostium tejonensis........................ 37

Turbonilla raymondi........................... 42

tenuicula............................... 42 valdezi

Turritella buwaldana......................... 37 cooperi...................................... 42 lawsoni_............................. 15, 20, 37 secondaria ...- 37 uvasana etheringtoni......................... 20,37

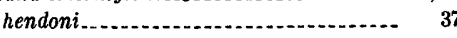

Page

Turtonia minuta

U

Uvas member, Tejon formation

V

Vegetation................................. 4-5

Velutina laevigata............................ 42,50

Ventricolaria fordii........................... 46,55

Vitrinella oldroydi............................. 40

stearnsii

Volutocristata lajollaensis _........................ 37

W

Water paleotemperatures.................... 39,51

Water resources........ 57-59

Water temperature variation off southern California and northwestern Baja California............................ 51

Wildlife .......................... 4-5

Windblown sand............................... 30-32

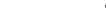

Zonaria spadicea 
The U.S. Geological Survey Library has cataloged this publication as follows :

Vedder, John Graham, 1926-

Geology of San Nicolas Island, California, by J. G. Vedder and Robert M. Norris. Washington, U.S. Govt. Print. Off., 1963.

vi, 65 p. illus., maps, diagrs., tables. $29 \mathrm{~cm}$. (U.S. Geological Survey. Professional paper 369)

Part of illustrative matter folded in pocket.

Prepared in cooperation with the U.S. Department of the Navy, Office of Naval Petroleum and Oil Shale Reserves.

Bibliography : p. 59-62.

(Continued on next card)

Vedder, John Graham, 1926-

Geology of San Nicolas Island, California. 1963. (Card 2)

1. Geology-California-San Nicolas Island. 2. Paleontology-California-San Nicolas Island. I. Norris, Robert Matheson, 1921-, joint author. II. U.S. Office of Naval Petroleum and Oil Shale Reserves. III. Title: San Nicolas Island, California. (Series) 